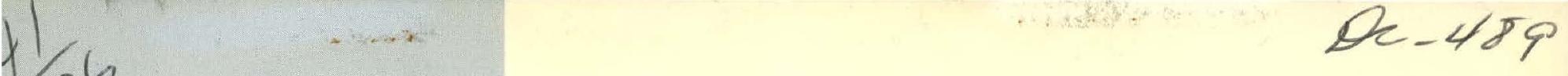

Y-1754

Revision 1

\title{
X-RAY AND NUCLEAR RADIATION FACILITIES, PERSONNEL SAFETY FEATURES
}

\author{
W. J. Mason \\ E. W. Pipes \\ T. R. Rucker \\ D. N. Smith \\ C. M. West
}

\section{MASTER}




\section{DISCLAIMER}

This report was prepared as an account of work sponsored by an agency of the United States Government. Neither the United States Government nor any agency Thereof, nor any of their employees, makes any warranty, express or implied, or assumes any legal liability or responsibility for the accuracy, completeness, or usefulness of any information, apparatus, product, or process disclosed, or represents that its use would not infringe privately owned rights. Reference herein to any specific commercial product, process, or service by trade name, trademark, manufacturer, or otherwise does not necessarily constitute or imply its endorsement, recommendation, or favoring by the United States Government or any agency thereof. The views and opinions of authors expressed herein do not necessarily state or reflect those of the United States Government or any agency thereof. 


\section{DISCLAIMER}

Portions of this document may be illegible in electronic image products. Images are produced from the best available original document. 


\section{Printed in the United States of America. Available from National Technical Information Service \\ U.S. Department of Commerce \\ 5285 Port Royal Road, Springfield, Virginia 22161 \\ Price: Printed Copy \$5.00; Microfiche $\$ 2.25$}

This report was prepared as an account of work sponsored by the United States Government. Neither the United States nor the Energy Research and Development Administration, nor any of their employees, nor any of their contractors, subcontractors, or their employees, makes any warranty, express or implied, or assumes any legal liability or responsibility for the accuracy, completeness or usefulness of any information, apparatus, product or process disclosed, or represents that its use would not infringe privately owned rights. 
Date of Issue: October 25, 1976

Report Number: Y-1754 (Rev 1)

Distribution Category: UC-41

\title{
X-RAY AND NUCLEAR RADIATION FACILITIES, PERSONNEL SAFETY FEATURES
}

\author{
W. J. Masurı \\ E. W. Pipes \\ T. R. Rucker \\ D. N. Smith \\ C. M. West
}

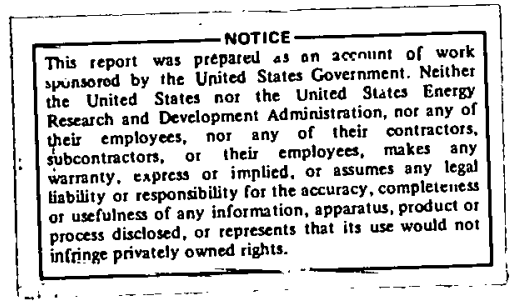

Oak Ridge Y-12 Plant

P. O. Box Y, Oak Ridge, Tennessee 37830

\footnotetext{
Prepared for the US Energy Research and Development Administration 


\section{ABSTRACT}

Development and implementation of these standards are described and the general philosophy and approach to these standards are outlined. Use of a matrix (type of installation versus radiation safety feature) to facilitate equipment classification and personnel safety feature requirements is presented. Included is a set of the standards showing formats, matrices, etc, and the detailed standards for each safety feature. 


\section{CONTENTS}

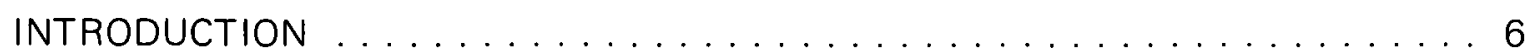

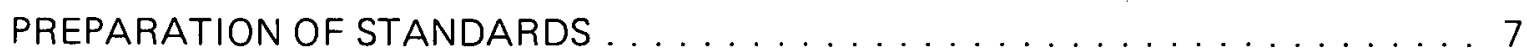

ACKNOWLEDGEMENTS $\ldots \ldots \ldots \ldots \ldots \ldots \ldots \ldots \ldots$

X-RAY AND NUCLEAR RADIATION FACILITIES PERSONNEL SAFETY FEATURES-

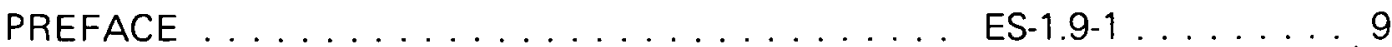

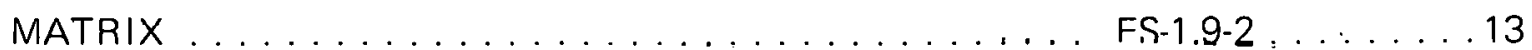

FACILITIES' CLASSIFICATION AND DESCRIPTION . . . E ES-1.9-3 . . . . . 14

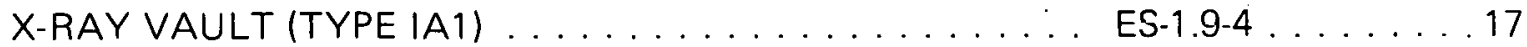

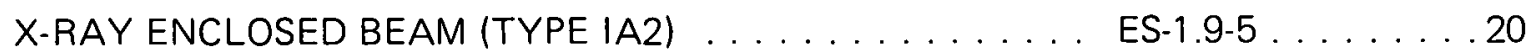

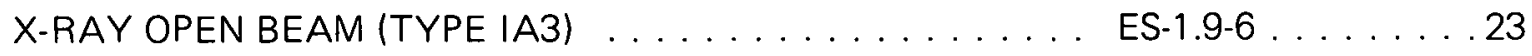

X-RAY STORAGE FACILITIES (TYPE IB) . . . . . . E ES-1.9-7 . . . . 26

RADIOACTIVE SOURCE VAULT (TYPE $\| A 1) \ldots \ldots . \ldots$ ES-1.9-8 . . . . . . 27

RADIOACTIVE SOURCE ENCLOSED BEAM

(TYPE IIA2)

ES-1.9-9 . . . . 30

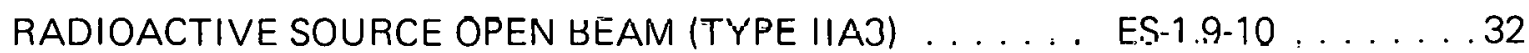

RADIOACTIVE SOURCE STORAGE FACILITY

(TYPE IIB)

ES-1.9-11 .35

RADIOACTIVE SOURCES LESS THAN 50 MILLI-

CURIES (TYYE IIC)

ES-1.9-12 . . . . 37

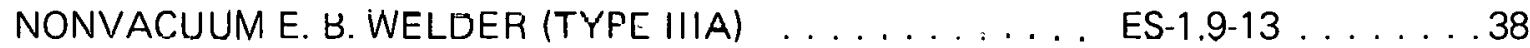

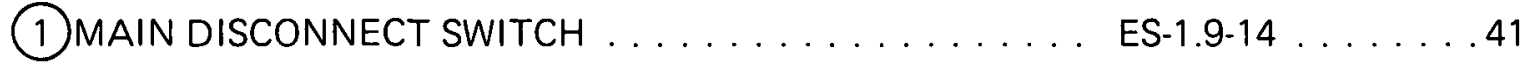

(2) MILLIAMP AND KILOVOLT METERS .......... ES-1.9-15 . . . . 42

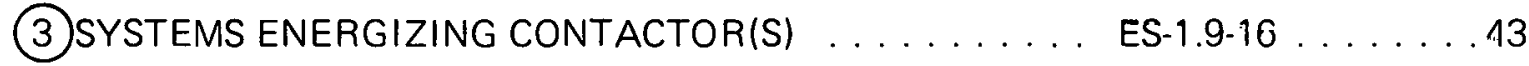


(4)VOLTAGE SENSING DEVICE . . . . . . . . . . ES-1.9-17 . . . . 44

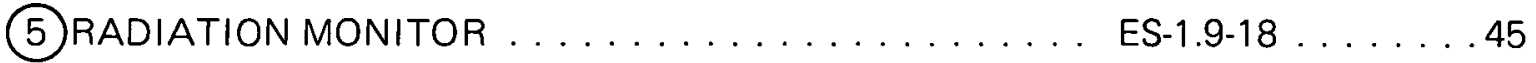

(6) SOLENOID DOOR LOCK ... . . . . . . . . ES-1.9-19 . . . .46

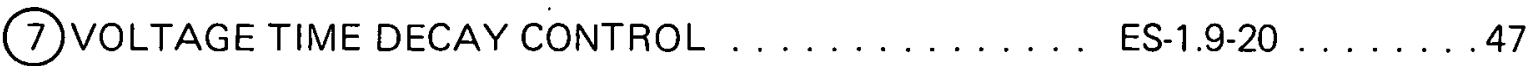

(8)ACCESS DOOR INTERLOCK ... . . . . . . ES-1.9-22 . . . . 49

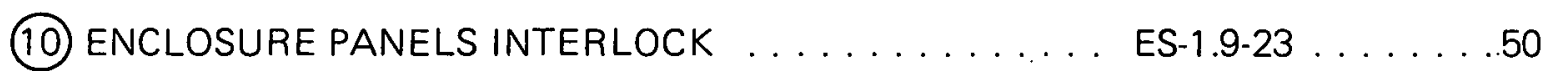

(11) RADIATION SHIELD INTERLOCK . . . . . . . . ES-1.9-24 . . . . 51

(12) BARRICADE INTERLOCK . . . . . . . . . . ES-1.9-25 . . . . 52

(13) SCRAM SWITCH INTERLOCK . . . . . . . . E ES-1.9-26 . . . . 53

(14)FORCED INSPECTION INTERLOCK . . . . . . . . . E ES-1.9-27 . . . . . 54

(15) RADIATION BEAM POSITION INTERLOCK . . . . . . ES-1.9-28 . . . . 55

(16) LIGHT FAILURE INTERLOCK . . . . . . . . . . . ES-1.9-29 . . . . . 56

(17) KEY LOCK-OUT INTERLOCK . . . . . . . . . ES-1.8.30 . . . . 80

(18) FAIL STRIP INTERLOCK . . . . . . . . . . E ES-1.9-31 . . . 662

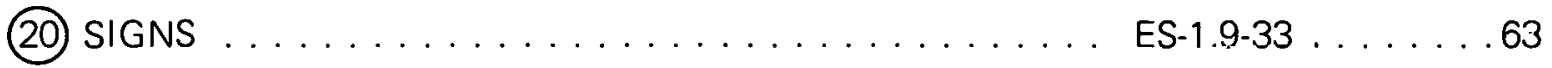

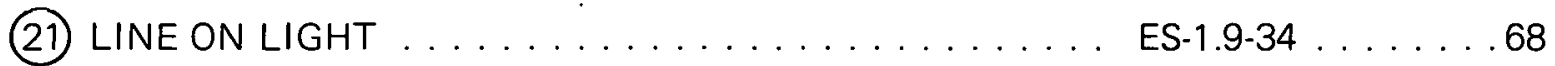

(22) SYSTEM ARMED LIGHT . . . . . . . . . ES-1.9-35 . . . 69

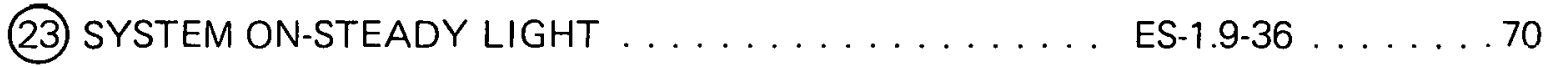

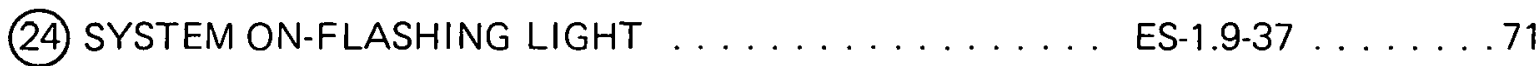

(25) VSD ON/SOURCE EXPOSED-FLASHING LIGHT . . . E ES-1.9-38 . . . . 74

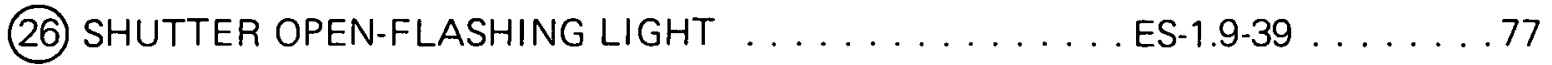

(27) SHUTTER CLOSED-STEADY LIGHT . . . . . . . . ES-1.9-40 . . . 78

(28) X-RAY OFF/SOURCE SHIELDED LIGHT . . . . . . . ES-1.9-41 . . . .79

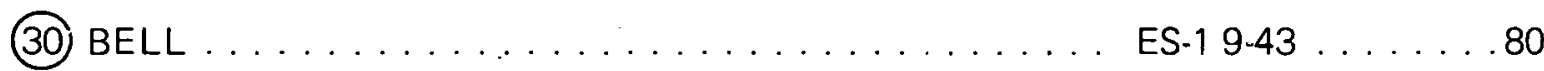




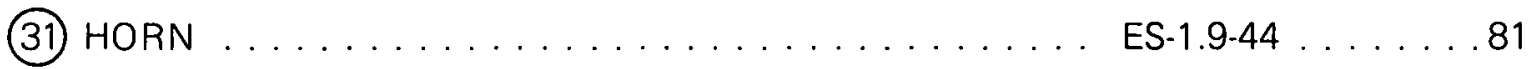

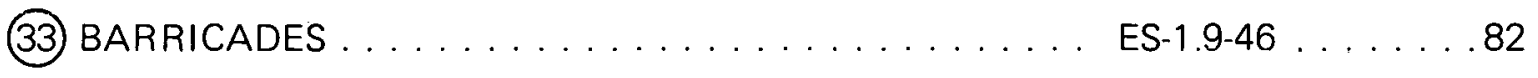

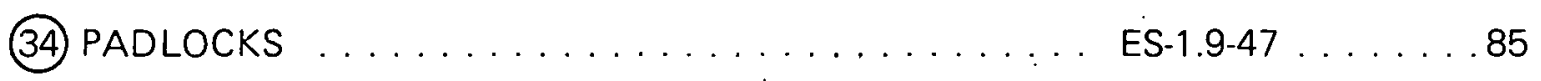




\section{INTRODUCTION}

The Oak Ridge $\mathrm{Y}-12$. Plant $(\mathrm{a})$ is a research and production installation. The nature and versatility of this work require the use of a large number and variety of $X$-ray and radiographic sources for nondestructive testing and material analyses. Presently, there are over $80 \mathrm{X}$-ray generators in the Plant, which range in size from small, portable units which operate at a less than 50 kilovolts potential and 0.1 milliampere current to an electron linear accelerator which operates at 12-million electron volts and produces a radiation beam of such intensity that it could deliver a lethal dose to man in a fraction of a minute. There are also almost 50 gamma and neutron sources in use in the Plant. These units range in size from a few millicuries to several hundred curies.

The Plant's approach to safety in these facilities has been to consider specific features for each at the time of its design. Such an approach over the period of the last twenty-five years resulted in a multiplicity of combinations and types of safety features. In order to assure consistency and adequacy of the radiation safety features in future installations as well as to develop criteria for upgrading present installations, engineering standards were developed for the safety circuits and equipment associated with such installations.

Although the radiation safety at each of these facilities was considered adequate, the administrative and maintenance procedures became unduly complicated. Accordingly, Engineering standards and uniform operating procedures were considered necessary to alleviate these complications and, in so doing, provide an improved measure of radiation safety.

(a) Operated by the Union Carbide Corporation's Nuclear Division for the US Energy Research and Development Administration. 


\section{PREPARATION OF STANDARDS}

The first step in the preparation of these standards was the development of a set of guidelines by a committee of Plant specialists representing the operations, maintenance engineering, and radiation safety groups.

The guidelines incorporated the following major points:

1. Standards should meet or exceed the requirements in nationally accepted standards.

2. Shielding of the radiation field should be accomplished whenever feasible.

3. Interlocks and other safety and warning features should be provided to supplement or complement the safety afforded by enclosures.

4. Use of shielding and/or other radiation safety features should be comensurate with the level of radiation and/or exposure potential.

Engineering standards were developed for the definition and classification of $X$-ray and nuclear radiation facilities and for the specification of various personnel safety features required for these facilities. A matrix (Section ES-1.9-2) was prepared to list, in concise form, the personnel safety features that were either required, optional, or not applicable to each facility classification. The matrix illustrates not only that different classifications of $X$-ray and nuclear radiation facilities require different personnel safety features, but that differences in radiation level and exposure potential within each facility classification justify the requirement of more safety features for some facilities than others. Facility classifications are described in Sertions ES-1.9-3 through 13, along with definitions, schematics with illustrations, and listings of personnel safety feature requirements.

Detailed information on personnel safety features including defiritions, descriptions, example of approved circuitry and/or equipment, devices, etc, is contained in Sections ES-1.9-14 through 47. 


\section{ACKNOWLEDGEMENTS}

These standards for radiation safety features at nondestructive testing and material analysis facilities were fostered and approved by a committee of the following $Y-12$ personnel: T. H. Barton, L. E. Burkhart, V. C. Jackson, D. A. Jones, C. M. Knowles, D. L. Mason, W. J. Mason, J. D. McLendon, G. W. Oliphant, E. W. Pipes, E. Roberts, Jr, T. R. Rucker, D. N. Smith, H. G. Smith, S. G. Snow, L. M. Van Arsdall, and C. M. West. A task group consisting of W. J. Mason, E. W. Pipes, T. R. Rucker, D. N. Smith, and C. M. West was selected to carry out the detailed development of the standards. E. W. Pipes and H.W. Zang were responsible for preparing the engineering details of the standards. 


\section{SCOPE}

This standard outlines design requirements for specification, procurement, or construction of safety devices for installation on X-ray and nuclear radiation facilities to assure protection of personnel from harmful ionizing radiation.

\section{APPLICABLE STANDARDS}

Unless otherwise specified in this standard or on the drawings, the latest revision of the folluwing slandards shall apply as minimum requirement.s for the manufacture, installation, operation, use, and maintenance of industrial equipment which may give off radiation from radioactive materials or $\mathrm{X}$-rays:

ANSI Z54.1-1963 - "Safety Standard for Non-Medical X-Ray and Sealed GammaRay Source."

Y-12 Plant Health and Safety Manual, Volume 1, Procedure 70-100, "Health Physics and Industrial Hygiene."

Y-12 Plant Health and Safety Procedures, Volume 1, Procedure 70-102, "X-Ray Equipment and Radioactive Sources."

\section{GENERAL}

For purposes of this standard, all X-ray and nuclear radiation sources are classified by typc of operating or storage facility. Personnel safety features are classified and described according to safety function. A descriptive matrix, Engineering Standard ES-1.9-2, designates required or optional safety features applicable to each classification of radiation facility. An " $X$ " symbol at a malrix junction indicatcs that the safety feature is required (shall be installed) on the radiation facility. Exceptions for specific facilities will be authorized only after review and concurrellice of a safety fcatures review committee. An "O" symbol at a matrix junction indicates that need for the safety feature on any particular radiation facility will be determined by a safety features review committee.

Radiation facility type numbers (derived from top of the matrix) and safety feature device numbers (from left side of matrix) are used throughout these standards for identifying, classifying, and describing the radiation facilities and safety devices.

These safety standards apply to industrial applications of X-ray and nuclear radiation facilities and supplement the requirements as set forth in ANSI Z54.1-1963 and Y-12 Plant Health and Safety Manual Procedures 70-100 and 70-102. 
RM RADIATION MONITORING DEVICE

MX RADIATION MONITOR AUX. DEVICE

B BELL

H HORN

(SR HORN SILENCE RELAY

(LC) LINE contactor

XR1 SYSTEM ENERGIZING CONTACTOR

XR2 SYSTEM ENERGIZING REDUNDANT CONTACTOR

(M) FLASHER MOTOR

VSU VOLTAGE SENSING DEVICE

vi voltage SENSING RELAY

VSX VSD AUX. RELAY

LFD LIGHT FAILURE DEVICE

(LF) LIGHT FAILURE RELAY

LFX LIGHT FAILURE AUX. RELAY

FSD FAIL STRIP DEVICE

(FS) FAIL STRIP RELAY

FSX FAIL STRIP AUX. RELAY

RIBBON SWITCH

SOL SOLENOID OPERATED SWITCH
RY1 OPEN SHIELD PILOT RELAY

XRX SYSTEM ENERGIZING CONTACTOR AUX. RELAY

RY2 ClOSE SHIELD PILOT RELAY

(OS) OPEN SHIELD MOTOR STARTER

UPX SHIELD OPENED AUX. RELAY

(CS) CLOSE SHIELD MOTOR STARTER

(DNX) SHIELD CLOSED AUX. RELAY

R. LINE ON (RED LIGHT)

A. SYSTEM ARMED (AMBER LIGHT)

' $(R)^{\prime \prime}$ SYSTEM ON (RED OR MAGENTA LIGHT)

G X-RAY OFF/SOURCE SHIELDED (GREEN

WhIELD OPEN/SOURCE IN OPERATING POSITION (WHITE LIGHT)

Y AUX. INTERLOCK DEVICE (YELLOW LIGHT)

(SDL) SOLENOID DOOR LOCK

TDR TIME DELAY RELAY

TDR-1 VOLTAGE TIME DECAY

TIME DELAY

TDR-2 BELL TIME DELAY

TDR-3 HORN TIME DELAY

TDR-4 DUAL HEAD, VOLTAGE TIME

DECAY AND HORN TIME

DELAY 


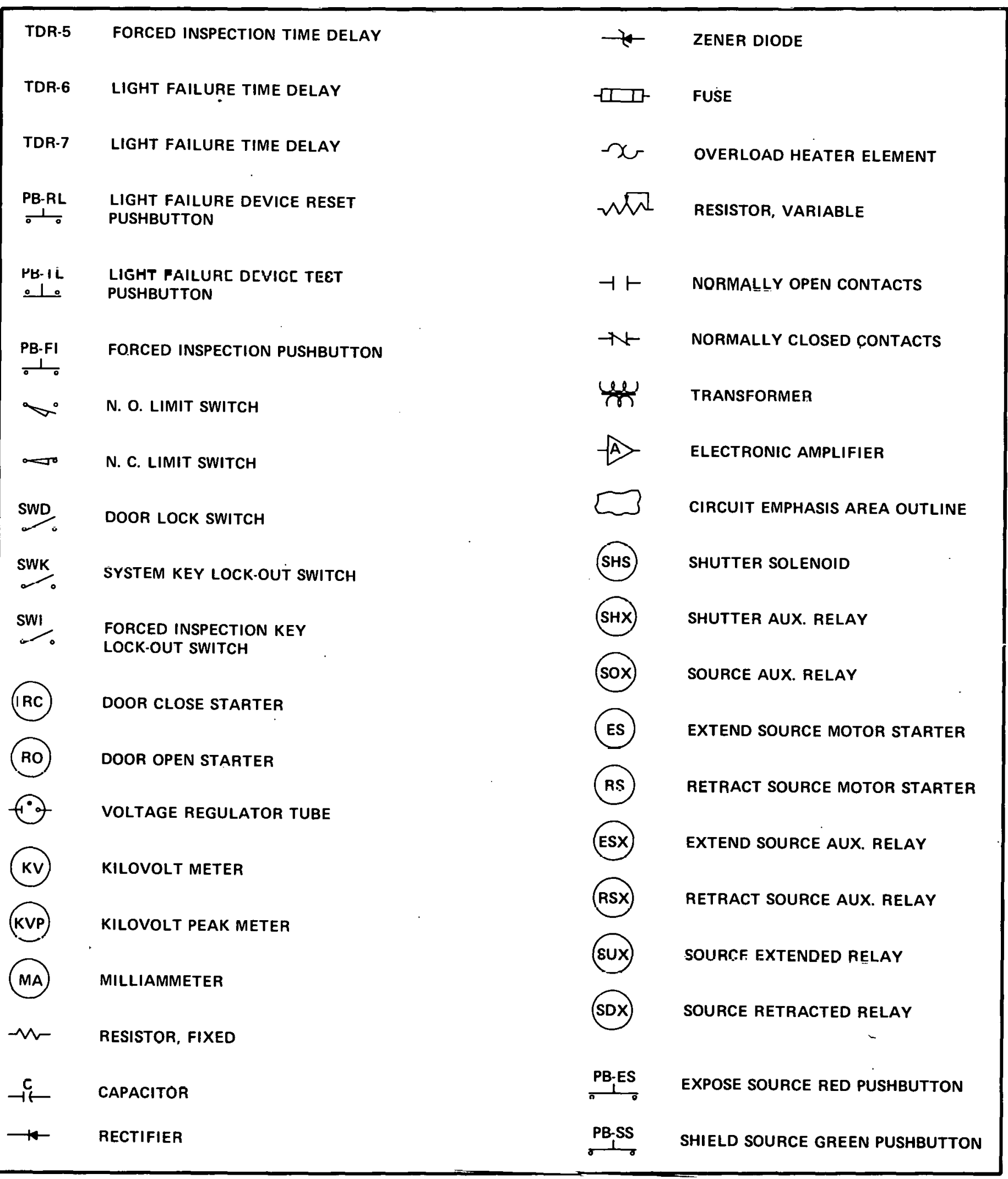


PB-LS EMERGENCY LOWER SOURCE RED PUSHBUTTON

PB-LC-ON LINE CONTROL ON RED PUSHBUTTON -

PB-LC-OFF LINE CONTROL OFF GREEN PUSHBUTTON

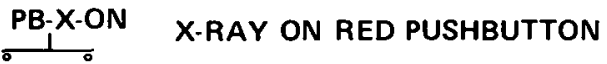

PB-X-OFF X-RAY OFF GREEN PUSHBUTTON 


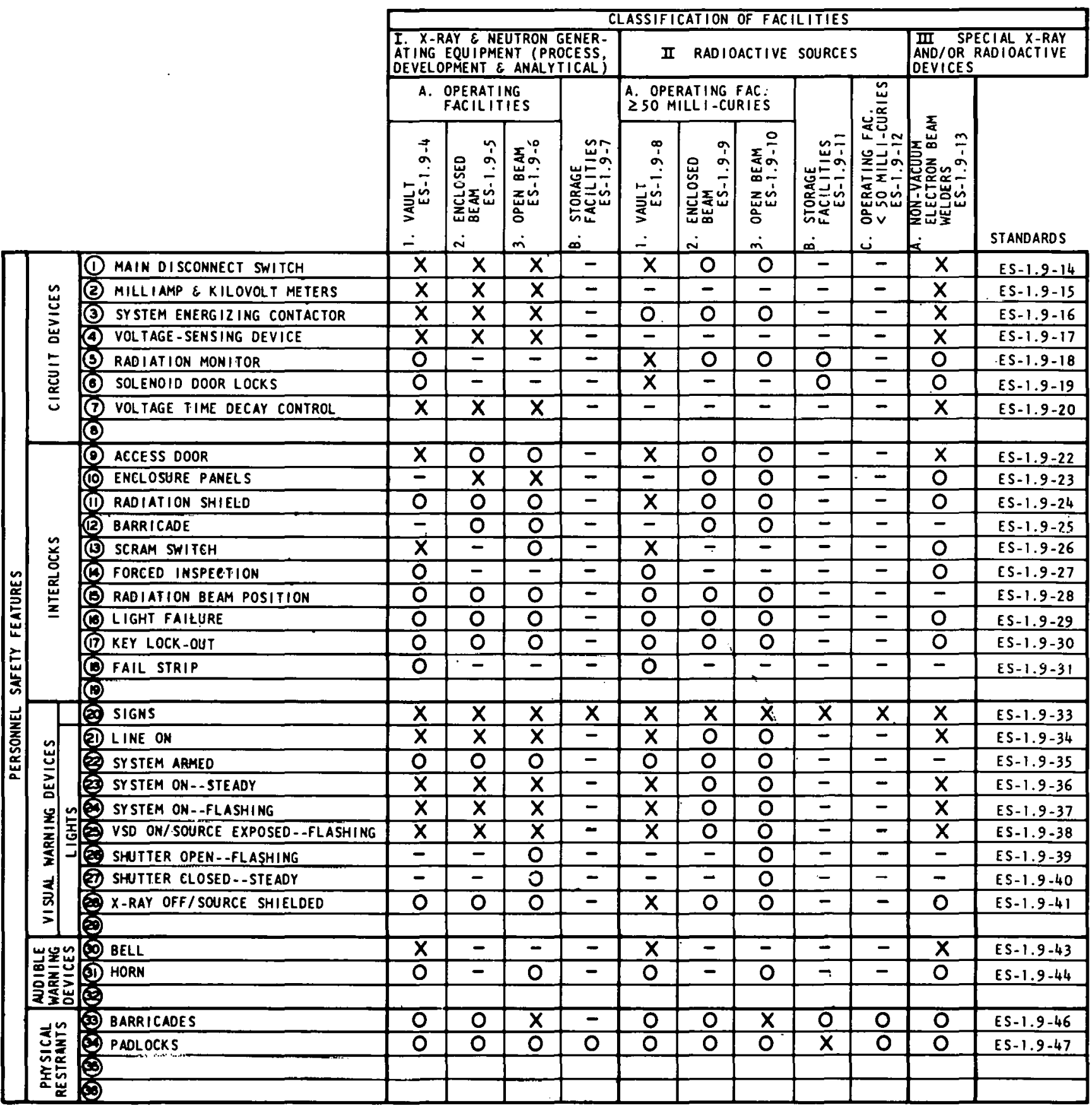

$X$ hequiaed as nOted IN OEFINITION. EXCEPTIONS FOR SPECIFIC FACILITIES WILL Be AUTHORIZED ONLY AFTER REVIEW ANO CONCURRENCE OF A SAFETY FEATURES REVIEW COMMITTEe

O special - each category 80 moted shall be considered on an individual basis. DECIBION AB TO MEEO BHALL BE REBOLVED BY A SAFETY FEATURES REVIEW COMMITTEE. 


\section{A. VAULT FACILITY - TYPE IA1 (REFERENCE ES-1.9-4) OR TYPE IIA1 (REFERENCE ES-1.9-8)}

A vault facility is a permanent enclosure for radiation-producing equipment or sources large enough for personnel to bodily enter but within which no person is permitted to remain during irradiation.

The permanent enclosure is most frequently a shielded room with a maze and/or shielding door. Reliable safety features are provided to prevent access to the enclosure during irradiation. Engineering design of personnel safety features for vaults will meet or exceed the requirements for an "exempt protective installation" as prescribed in N.B.S. Handbook \#93, "Safety Standards for Non-Medical X-Ray and Sealed Gamma-Ray Sources."

\section{B. ENCLOSED BEAM FACILITY - TYPE IA2 (REFERENCE ES-1.9-5) OR TYPE I!A2 (RCFERENCE ES-1.9-9)}

An enclosed beam facility is a permanent enclosure for radiationproducing equipment or sources so designed that the radiation is enclosed by a physical barrier in such a way that it is not accessible for personnel exposure.

An enclosed beam facility differs from a vault facility in that it is not large enough for personnel to enter. If there are doors, removable shields, etc., which permit personnel access to the locations where there would be radiation, reliable safety features are provided to prevent irradiation during such access. Engineering designs of personnel safety features for enclosed beam facilities will meet or exceed the requirement for "exempt protective installation" as prescribed in N.B.S. Handbook \#93, "Safety Standards for Non-Medical X-Ray and Sealed Gamma-Ray Sources". 


\section{OPEN BEAM FACILITY - TYPE IA3 (REFERENCE ES-1.9-6) OR TYPE IIA3 (REFERENCE ES-1.9-10)}

An open beam facility is a facility with radiation-producing equipment or sources which is not enclosed or contained in a vault.

Ain upen bcam facility is used only when nperating requirements are such that the inherent degree of protection provided by the vault or enclused beam facility is not feasible. Engineering design of personnel safety features for open beam radiation facilities will meet or exceed the requirements for "open protective installations" as prescribed in N.B.S. Handbook \#93, "Safety Standards for Non-Medical X-Ray and Sealed GammaRay Sources."

\section{STORAGE FACILITY - TYPE IB (REFERENCE ES-1.9-7) OR TYPE IIB (REFERENCE ES-1.9-11)}

A storage facility is an area or enclosure used for the storage of sources or radiation-producing equipment.

Radiation-producing equipment and sources which are not in current use fall into a storage-facility category. The above should also mcet storage facility requirements if they are currently in use but are left unattended. Some examples of storage facilities are storage rooms, areas, storage pigs for large sources, desk drawers, and file cabinets for small sources.

\section{E. RADIATION SOURCE LESS THAN 50 MILLI-CURIES - FACILITY TYPE IIC (REFERENCE ES-1.9-12)}

Any nuclear radiation source of less than 50 milli-curies that is used in an operating facility. 


\section{E. CONTINUED}

Some examples of this type radiation facility are:

1. Radioactive paint on gas filled electronic tubes to cause gas ionization.

2. Radiation sources used as components of signal sensors in smoke detectors and other electronic instruments.

3. Radiation sources used as failsafe elements in radiation-monitor systems.

F. NONVACUUM ELECTRON BEAM WELDERS - FACILITY TYPE IIIA (REFERENCE ES-1.9-13)

An electron beam welder in which the electron beam is not enclosed in a vacuum chamber.

Although an electron beam welder is not for the purpose of producing radiation, the fact that such welders operate at relatively high amperages and voltages make them highly effective $\mathrm{X}$-ray generators. Consequently nonvacuum electron beam welder facilities must be installed with radiation safety features which are equivalent to safety features on $X$-ray machines of equal exposure potential. 


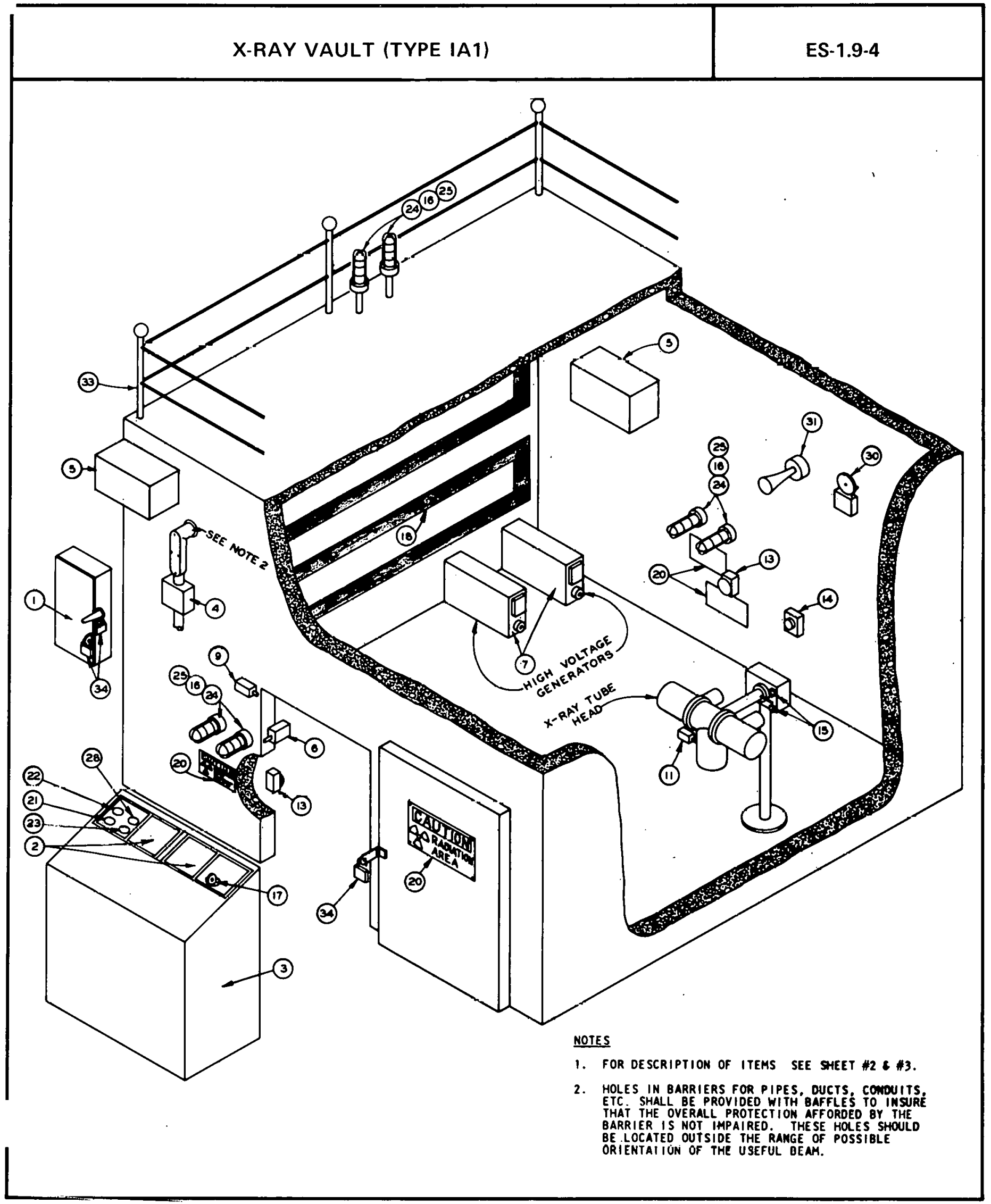


GENERAL

THIS STANDARD OUTL INES THE REQUIREMENTS FOR EQUIPPING VAULT TYPE X-RAY FACILITIES WITH SAFETY DEVICES TO PROTECT.PERSONNEL FROM HARMFUL IONIZING RABIATION.

\section{REQUIREMENTS}

IT IS REQUIRED THAT VAULT TYPE X-RAY FACILITIES BE EQUIPPED WITH THE FOLLOWING SAFETY FEATURES: THESE ITEMS ARE NOTEO BY AN "X" SYMBOL ON ES-1.9-2. EXCEPTIONS FOR SPECIFIL FACILITIES WILL BE AUTHORIZED ONLY AFTER REVIEW AND CONCURRENCE OF A SAFETY FEATURES REVIEW COMMITTEE.

\begin{tabular}{|c|c|c|}
\hline SAFETY FEATURES & REF, SI'DS & REMARKS \\
\hline \multicolumn{3}{|l|}{ CIRCUIT DEVICES } \\
\hline (1) MAIN DISCONNECT SWITCH & ES-1.9-14 & INSIALL OUISIDE VAULT, NEAR \& IN SIGHI OF GONIROL PANEL. \\
\hline (2) MILLIAMP \& KILOVOLT METERS & ES-1.9-15 & INTEGRAL WITH CONTROL CONSOLE. \\
\hline \multirow[t]{3}{*}{ (3) SYSTEM ENERG IZ ING CONTACTOR } & ES-1.9-16 & MUST BREAK ALL $X$-RAY HIGH VOLTAGE TRANSFORMER ENERGIZING CONOUCTORS, IF \\
\hline & & OUTPUT IS $25 \mathrm{r} / \mathrm{MIN}$. /METER, TWO CONTACTORS (REDUNDANT) SHALL BE INSTALLED \\
\hline & & TO INDEPENOENTLY BREAK ALL HIGH VOLTAGE IRANSFORMER CONDUCTORS. \\
\hline \multirow[t]{2}{*}{ (4) VOLTAGE-SENSING DEVICE } & ES $-1.9-17$ & INSTALL AS NEAR TO THE HIGH VOLTAGE TRANSFORMER AS PRACTICAL AND CONHECI \\
\hline & & DIRECTLY ACROSS THE PRIMARY LEADS OF THE TRANSFORMER. \\
\hline \multirow[t]{2}{*}{ (7) VOLTAGE TIME DECAY CONTROL } & $E S-1.9-20$ & MUSI QI SCHARFF Q.5SIDUAL $X$-RAI POHEK SUPPLY VOLTȦGE BEFORE PERSONNEL CAN \\
\hline & & ENTER VAULT. \\
\hline & & \\
\hline \multicolumn{3}{|l|}{ INTERL OCKS } \\
\hline \multirow{3}{*}{$\begin{array}{l}\text { (0) ACCESS DOOR INTERLOCK } \\
\text { (13) SCRAM SWITCH INTERLOCK }\end{array}$} & $E S-1.9-22$ & ELECTRICALLY INIERLOCK ALL ACCESS DOORS. \\
\hline & ES-1.9-26 & INSTALL INSIOE VAULT FOR EMERGENCY SHUTDOWN, TWO OR MORE SWITCHES SHOULD \\
\hline & & BE INSTALLED IN LARGE VAULTS. \\
\hline 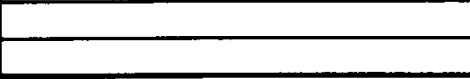 & & \\
\hline \multicolumn{3}{|l|}{ VISUAL WARNINǴ DEVICES } \\
\hline \multirow[t]{2}{*}{ SIGNS } & ES-1.9-33 & NUMBER, TYPE, ANO LOCATION OF SIGNS FOR FACILITY ARE DEIERMINED BY \\
\hline & & OPERATIONS AND RADIATION SAFETY DEPARTMENTS. \\
\hline \multirow{4}{*}{$\begin{array}{l}\text { (21) LINE ON LIGHT } \\
\text { (23) SYSTEM ON--STEADY LIGHT } \\
\text { SYSTEM ON--FLASHING LIGHT }\end{array}$} & ES-1.9-34 & RED LIGHT, INSTALLED ON X-RAY CONTROL CONSOLE. \\
\hline & ES-1.9-36 & RED OR MAGENTA LIGHT, INSTALLED ON X-RAY CONTROL. CONSOLE. \\
\hline & ES-1.9-37 & RED OR MAGENTA LIGHTS, NUMBER \& LOCAILON OETERMINER BY OPEBAJLONS. \\
\hline & & RADIATION SAFETY, AMD ENGIMEERING DEPARTMENTS. \\
\hline (3) VSD ON/SOURCE EXPOSED--FL. LT. & ES-1.9-38 & FLASHING LIGHTS RED OR MAGENTA. \\
\hline \multicolumn{3}{|l|}{ AUDIBLE WARNING DEVICES } \\
\hline (30) BELL & ES-1.9-43 & INSTALL INSIDE VAULT WHERE IT WILL BE AUDIBLE THROUGHOUT VAULT. \\
\hline
\end{tabular}


REQUIREMENTS CONT.

THE NEED FOR THE FOLLOWING SAFETY FEATURES ON EACH PARTICULAR X-RAY VAULT FACILITY WILL BE DETERMINED BY A SAFETY FEATURES REVIEW COMMITTEE. THESE ITEMS ARE NOTED BY AN "O" SYMBOL ON ES-1.9-2.

\begin{tabular}{|c|c|c|}
\hline SAFETY FEATURES & REF. STIDS & REMARKS \\
\hline \multicolumn{3}{|l|}{ CIRCU:IT DEVICES } \\
\hline \multirow[t]{2}{*}{ (5) RADIATION MONITOR } & $E S-1.9-18$ & NUMBER, TYPE, AND LOCATION OF MONITORS ARE. OETERMINED BY OPERATIONS \\
\hline & & AND RADIATION SAFETY DEPARTMENTS. \\
\hline (C) SOLENOID DOOR LOCKS & ES-1.9-19 & PROVIDE MEANS FOR OVERRIOING DQOR LOCK EROM INSIOE YAULI. \\
\hline \multicolumn{3}{|l|}{ INTERLOCKS } \\
\hline (ii) RADIATION SHIELD INTERLOCK & $E S-1.9-24$ & ALLOW 8 X-RAY OPERATION ONLY WHEN SHIELOS ARE IN PLACE \\
\hline \multirow{2}{*}{ (4) FORCED INSPECTION INTERLOCK } & ES-1.9-27 & INSTALL FORCEO INSPECTION SWITCH SO THAT ENTIRE VAULT AREA MAY BE \\
\hline & & OBSERVED WHEN OPERATOR GOES TO AND FROM SWITCH LOCATION. \\
\hline \multirow[t]{2}{*}{ (15) RADIATION BEAM POSITION INTLK. } & ES-1.9-28 & LIMITS OF PERMISSIBLE X-RAY BEAM LOCATION ARE DEIERMIMED BY OPERALIONS \\
\hline & & ANO RADIATION SAFETY DEPARTMENTS. \\
\hline (16) LIGHT FAILURE INTEBLOCK & ES-1.9-29 & PREVENIS $X$-RAY OPERATION WHEN WARNING LUGHI IS IMOPERAUUY. \\
\hline (17) KEY LOCKOUT INTERLOCK & ES-1.9-30 & INSTALL ON OR NEÄR X-RAY CONTROL CONSOLE. \\
\hline \multirow[t]{2}{*}{ (B) FAIL STRIP INTERLOCK } & $E S-1.9-31$ & APPLY STRIP TO ALL SECIUONS OF YAULI ENCLLOSURE IHAI ARE SUBJECT TO \\
\hline & & UNINTENT IONAL BREAKAGE OR OPENING. \\
\hline \multicolumn{3}{|l|}{ VISUAL WARNING DEVICES } \\
\hline (39) SY STEM ARMED LIGHT & ES-1.2-35 & AMBER LIGHT INSIALLED ON X-BAY CONSOLE. \\
\hline (29) X-RAY OFF/ SOURCE SHIELDED LIGHT & ES-1.9-41 & GREEN LIGHT INSTALLED ON X-RAY CONSOLE. \\
\hline \multicolumn{3}{|l|}{ AUDIBLE WARNING DEVICES } \\
\hline (31) HORN & ES-1.9-44 & INSTALL INSIDE VAULT WHERE II WILL BE AUDIBLE THROUGHOUT VAULT, \\
\hline \multicolumn{3}{|l|}{ PHYSICAL RESTRAINTS } \\
\hline \multirow[t]{2}{*}{ (33) BARRICADES } & $E 5-1.9-46$ & TYPE ANO LOCATION OF BARRICAOES ARE OEIERMINEO BY OPEBAULONS BAOLAUUOM \\
\hline & & SAFETY, AND ENG INEERING OEPARTMENTS. \\
\hline \multirow[t]{2}{*}{ (34) PAOLOCKS } & ES-1.9-47 & LOCATION OF PAOLOCKS ARE DETERMINED BY OPERATIONS DEPARTMENI. \\
\hline & . & \\
\hline
\end{tabular}




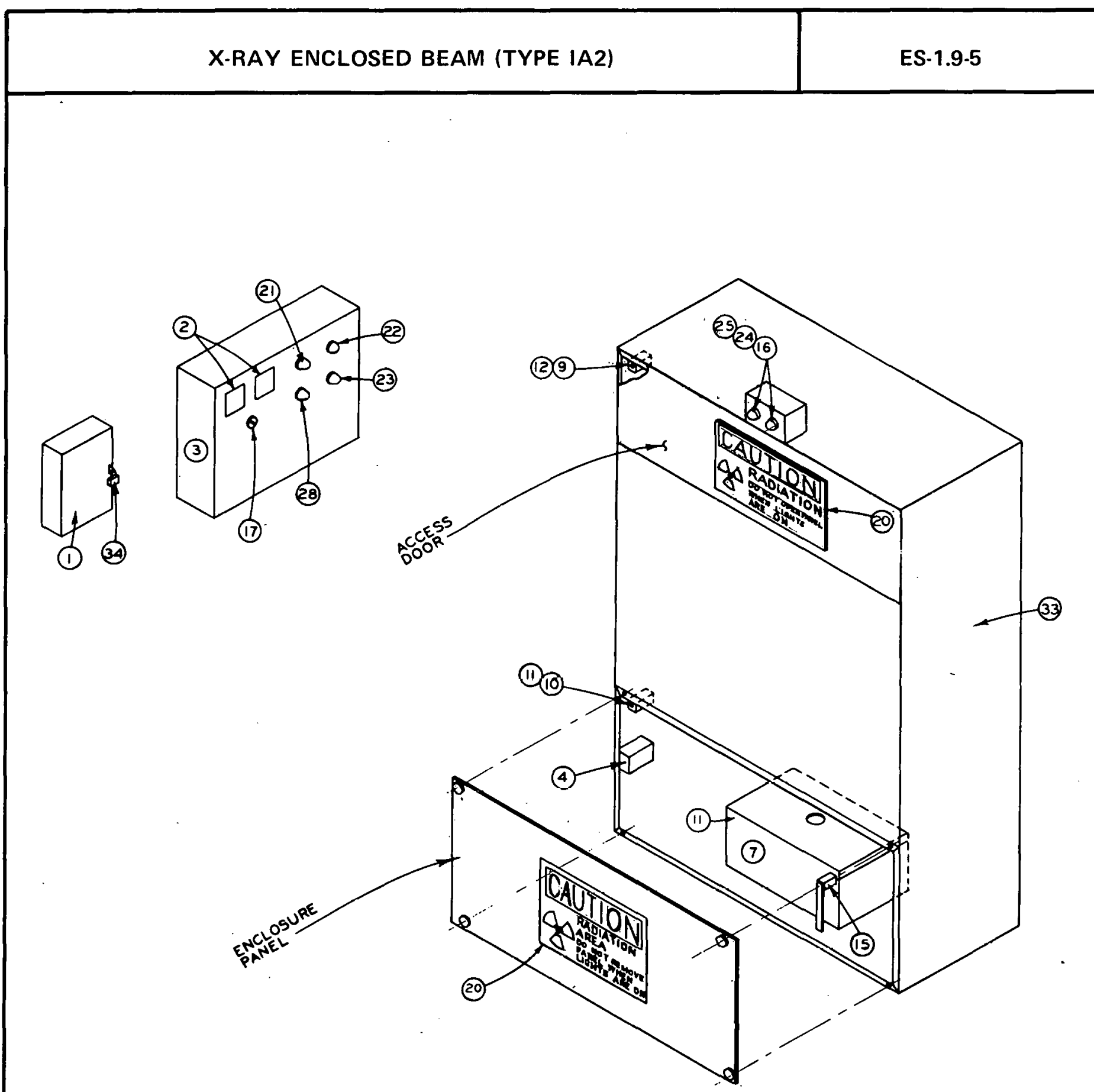

NOTE

1. NUMBERS IN CIRCLES REFER. TO ITEMS LISTEO ON

PAGES 2 OF 3 AND 3 OF 3. 
GENERAL

IHIS STANDARD OUTLINES THE REQUIREMENTS FOR EQUIPPING X-RAY ENCLOSED BEAM FACILITIES WITH SAFETY DEVICES TO PROTECT PERSONNEL FROM HARMFUL IONIZING RADIATION.

\section{REQUIREMENTS}

IT IS REQUIRED THAT X-RAY ENCLOSED BEAM FACILITIES BE EOU.IPPED WITH THE FOLLOWING SAFETY FEATURES. THESE ITEMS ARE

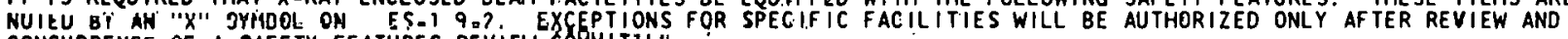
COHCURRENCE OF A SAFE.TY FEATURES REVIEW UOMMITIEE.

\begin{tabular}{|c|c|c|}
\hline SAFEIY FEATURES & REF, SI'DS. & REMARKS \\
\hline \multicolumn{3}{|l|}{ CIRCUIT DEVICES } \\
\hline (1) MAIN DISCONNECT SWITCH & & CONTROL PANEL. \\
\hline \multirow{3}{*}{$\begin{array}{l}\text { (2) MILL IAMP \& KILOVOLT METERS } \\
\text { (3) SYSTEM ENERG I ING CONTACTOR }\end{array}$} & ES-1.9-16 & MUST BREAK ALL X-RAY HIGH VOLTAGE TRANSFORMER ENERGIZING CONDUCTORS \\
\hline & & IF OUTPUT IS $25 R / M I N / M E T E R$, TWO CONTACTORS (REDUNDANT) SHALL BE \\
\hline & & INSTALLED TO INDEPENDENTLY BREAK ALL HIGH VOL TAGE TRANSFORMER \\
\hline (4) VOLTAGE - SENSING DEVICE & & CONNECT DIRECTLY ACROSS THE PRIMARY LEADS OF THE TRANSFORMER. \\
\hline \multirow[t]{2}{*}{ (7) VOL TAGE TIME DECAY CONTROL } & ES-1.9-20 & MUST DISCHARGE RESIDUAL $X$-RAY POWER SUPPLY VOLTAGE BEFORE PERSONNEL \\
\hline & & CAN ENTER-ENCLOSURE. \\
\hline \multicolumn{3}{|l|}{ INTERLOCKS } \\
\hline (10) ENCLOSURE PANEL INTERLOCK & $E S-1.9-23$ & ELECTRI.CAL INTERLOCK \\
\hline \multicolumn{3}{|l|}{ VISUAL WARNING DEVICES } \\
\hline SO) SIGNS & & BY OPERATIONS AND RADIATION SAFETY OEPARTMENTS. \\
\hline \multirow{4}{*}{$\begin{array}{l}\text { (2) LINE ON LIGHT } \\
\text { SY STEM ON - - STEADY LIGHT } \\
\text { SY STEM ON--FLASHING LIGHT }\end{array}$} & ES-1.9-34 & RED LIGHT, INSTALLLED ON X-KAY CONTROL PANEL, \\
\hline & ES $-1.9-36$ & RED OR MAGENTA, INSTALLED ON X-RAY CONTROL PANEL. \\
\hline & ES-1.9-37 & RED CR MAGENTA, NUMBER \& LOCATION DETERMINED BY OPERATIONS, \\
\hline & & RADIATION SAFETY, AND ENG INEERING DEPARTMENTS. \\
\hline SS VSD ON/SOURCE EXPOSED - FL. LT. & ES-1.9-38 & FLASHING LIGHTS, RED OR MAGENTA. \\
\hline \multirow{2}{*}{\multicolumn{3}{|c|}{ AUDIBLE WARNING DEVICES }} \\
\hline & & \\
\hline & & \\
\hline \multirow{2}{*}{\multicolumn{3}{|c|}{ PHY SICAL RESTRAINTS }} \\
\hline & & \\
\hline & & \\
\hline
\end{tabular}


REQUIREMENTS CONT.

THE NEED FOR THE FOLLOWING SAFETY FEATURES ON EACH PARTICULAR X-RAY ENCLOSED BEAM FACILITY WILL BE DETERMINED BY A SAFETY FEATURF S REYIEW COMMITTEE. THESE ITEMS ARE NOTEO BY AN "O" SYMBOL ON ES-1.9-2.

\begin{tabular}{|c|c|c|}
\hline SAFEIY FEAIURES & REF, SI'DS, & REMARKS \\
\hline \multicolumn{3}{|l|}{ CIRCUIT DEVICES } \\
\hline & & \\
\hline & & \\
\hline \multicolumn{3}{|l|}{ INTERLOCKS } \\
\hline (9) ACCESS DOOR INTERLOCK & ES-1.9-22 & ELECTRICALLY INTERLOCK ALL AGCESS DOORS. \\
\hline (H) RADIATION SHIELD INTERLOCK & ES-1.9-24 & ELECTRICAL INTERLOCK. \\
\hline (12) BARRICADE INTERLOCK & $E 5-1.9-25$ & ELECTRICAL INTERLOCK. \\
\hline \multirow[t]{2}{*}{ (15) RADIATION BEAM POSITION INIERLOCK } & $E S-1.9-28$ & LIMITS OF PERMISSIBLE X-RAY BEAM LOCATION ARE DETERMINED BY \\
\hline & & OPERATIONS AND RADIATION SAFETY DEPARTMENTS. \\
\hline (16) LIGHT FAILURE INTERLOCK & ES-1.9-29 & PREVENTS X-RAY OPERATION WHEN WARNING LIGHT IS INOPERATIVE. \\
\hline (17) KEY LOCK-OUT INTERLOCK & ES-1.9-30 & INSTALLED ON OR NEAR X-RAY CONTROL CONSOLE. \\
\hline \multicolumn{3}{|l|}{ VISUAL WARNING DEVICES } \\
\hline 22) SYSTEM ARMED LIGHT & $E S-1.9-35$ & AMBER LIGHT INSTALLEO ON X-RAY CONTROL CONSOLE. \\
\hline (28) X-RAY OFF/ SOURCE SHIELDED LIGHT & ES-1.9-41 & GREEN LIGHT INSTALLEO ON X-RAY CONTROL CONSOLE. \\
\hline \multicolumn{3}{|l|}{ AUDIBLE WARNING DEVICES } \\
\hline & & \\
\hline & & \\
\hline \multicolumn{3}{|l|}{ PHYSICAL RESTRAINTS } \\
\hline \multirow[t]{2}{*}{ (33) BARR I CADES } & ES-1.9-46 & TYPE AND LOCATION OF BARRICADES ARE DETERMINED BY OPERATIONS, \\
\hline & & RADIATION SAFETY, AND ENGINEERING DEPARTMENTS. \\
\hline 34 PADLOCKS & $E S-1.9-47$ & LOCATION OF PADLOCKS ARE DETERMINED BY OPERATIONS DEPARTMENT. \\
\hline
\end{tabular}



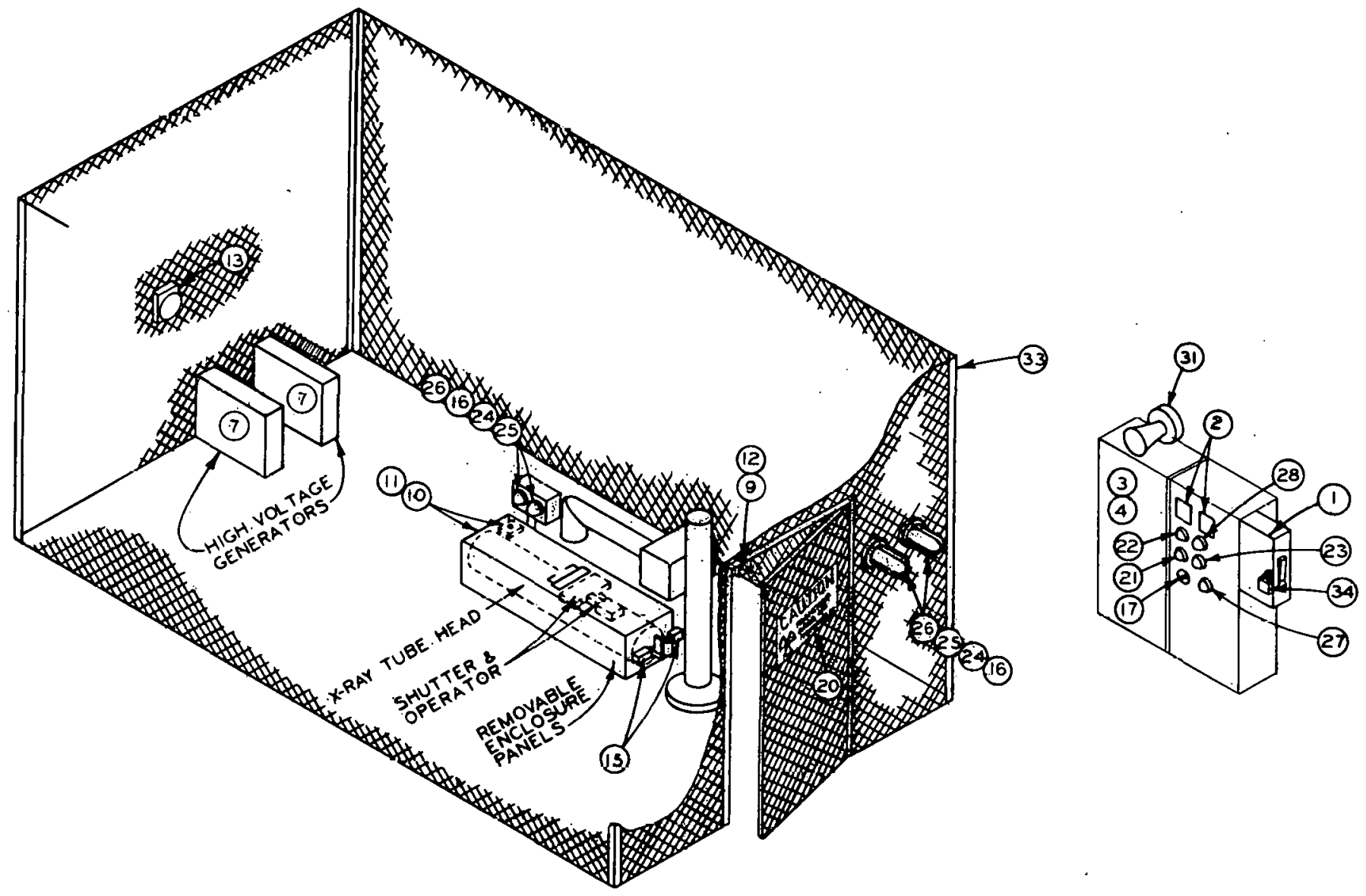

NOTE

1. NUMBERS IN CIRCLES REFER TO ITEMS LISTEO ON PAGES

2 OF 3 AND 3 OF 3 .

2. DISCONHECT SWITCH ANO CONTROL PANEL SHOULD BE MOUNTED ON UNISTRUT RACKING ADJACENT TO ENCLOSURE. 
GENERAL

THIS STANDARD OUTLINES THE REQUIREMENTS FOR EQUIPPING $X$-RAY OPEN BEAM FACILITIES WITH SAFETY DEYICES TO PROTECT PERSONNEL FROM HARMFUL IONIZ ING RADIATION.

\section{REQUIREMENTS}

IT IS REQUIRED THAT X-RAY OPEN BEAM FACILITIES BE EOUIPPED WITH THE FOLLOWING SAFETY FEATURES THESE ITEMS ARE NOTED BY AN "X" SYMBOL ON ES-1.9-2. EXCEPTIONS FOR SPECIF IC FACILITIES WILL BE AUTHORIZED ONLY AFTER REVIEW AND CONCURRENCE OF A SAFETY FEATURES REVIEW COMMITTEE.

\begin{tabular}{|c|c|c|}
\hline SAFETY FEATURES & REF. ST'OS. & REMARKS \\
\hline \multicolumn{3}{|l|}{ CIRCUIT DEVICES } \\
\hline (1) MAIN DISCONNECT SWITCH & ES-1.9-14 & INSTALL OUTSIDE VAULT, NEAR \& IN SIGHT OF CONTROL PANEL. \\
\hline (2) MILL IAMP \& KILOVOLT METERS & $E S-1.9-15$ & INTEGRAL WITH CONTROL CONSOLE. \\
\hline \multirow{3}{*}{ (3) SY STEM ENERG IZ ING CONTACTOR } & ES-1.9-16 & MUST BREAK ALL X-RAY HIGH VOLTAGE TRANSF ORMER ENERGIZING CONDUCTORS. \\
\hline & & IF OUTPUT IS 25 R/MIN. /METER, TWO CONTACTORS (REDUNDANT) SHALL BE \\
\hline & & INSTALLED TO INDEPENDENTLY BREAK ALL HIGH VOLTAGE TRANSF ORMER CONDUCTORS. \\
\hline \multirow[t]{2}{*}{ (4) VOLTAGE - SENSING DEVICE } & ES-1.9-17 & INSTALL AS NEAR TO THE HIGH VOLTAGE TRANSF ORMER AS PRACTICAL. AND \\
\hline & & CONNECT DIRECTLY ACROSS THE PRIMARY LEADS OF THE TRANSF ORMER. \\
\hline \multirow[t]{2}{*}{ (7) VOL TAGE TIME DECAY CONTROL } & ES-1.9-20 & MUST DISCHARGE RESIDUAL X-RAY POWER SUPPLY VOLTAGE BEFORE PERSONNEL \\
\hline & & TAN RFMNOVE X'RAY CNCLOJURE PANELS. \\
\hline & & \\
\hline \multicolumn{3}{|l|}{ INTERLOCKS } \\
\hline (10) ENCLOSURE PANELS INTERLOCK & ES-1.9-23 & ELECTRICALLY INTERLOCK ALL ENCLOSURE PANELS. \\
\hline 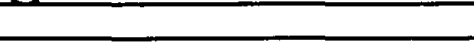 & & \\
\hline \multicolumn{3}{|l|}{ VISUAL WARNING DEVICES } \\
\hline \multirow[t]{2}{*}{ (8) SIGNS } & $E S-1.9-33$ & NUMBER, TYPE, AND LOCATION OF SIGNS FOR FACILITY ARE DETERMINED BY \\
\hline & & OPERATIONS AND RADIATION SAFETY DEPARTMENTS. \\
\hline \multirow{2}{*}{ (2) LINE ON LIGHT } & ES-1.9-34 & RED LIGHT, INSTALLED ON X-RAY CONTROL CONSOLE. \\
\hline & ES-1.9-36 & RED OR MAGENTA LIGHT, INSTALLEO ON X-RAY CONTROL CONSOLE. \\
\hline \multirow[t]{2}{*}{ (3) SY STEM ON--FLASHING LIGHT } & ES-1.9-37 & RED OR MAGENTA LIGHT, NUMBER \& LOCATION DETERMINED BY OPERATIONS, \\
\hline & & RADIATION SAFETY, AND ENGINEERING DEPARTMENTS. \\
\hline (2) VSD ON/SOURCE EXPOSED - FL. LT. & $E S-1.9-38$ & FLASHING LIGHTS. RED OR MAGENTA. \\
\hline \multicolumn{3}{|l|}{ PHYSICAL RESTRAINTS } \\
\hline \multirow[t]{2}{*}{ (33) BARR I CADES } & $E S-1.9-46$ & TYPES OF BARRICADES ARE DETERMINED BY OPERATIONS, RADIATION SAFETY, \\
\hline & & AND ENG INEERING DEPARTMENTS. \\
\hline & & \\
\hline & & \\
\hline
\end{tabular}


REQUIREMENTS CONT.

THF NFED FOR THE FOLLOWING SAFETY FEATURES ON EACH PARTICULAR OPEN BEAM FACILITY WILL BE DETERMINED BY

A SAFETY FEATURES KEVIEW COUNHITTEE. TIILSE ITEMS ARE NOTFN RY AN "O" SYMBOL ON ES-1.9-2.

\begin{tabular}{|c|c|c|}
\hline SAFETY FEATURES. & REF. ST'DS. & REMARKS \\
\hline \multicolumn{3}{|l|}{ INTERLOCKS } \\
\hline (11) RADIATION SHIELD INTERLOCK & ES-1.9-24 & ELECTRICAL INTERLOCK \\
\hline (13) SCRAM SWITCH INTERLOCK & $E S-1.9-26$ & EMERGENCY SHUTDOWN \\
\hline (15) RADIATION BEAM POSITION INTERLOCK & ES-1.9-28 & ELECTRICAL INTERLOCK \\
\hline (16) LIGHT FAILURE INTERLOCK & ES-1.9-29 & PREVENTS X-RAY OPERATION WHEN WARNING LIGHT IS INOPERATIVE \\
\hline \multicolumn{3}{|l|}{ VISUAL WARNING DEVICES } \\
\hline (22) SYSTEM ARMED LIGHT & ES-1.9-35 & AMBER LIGHT INSTALLED ON X-RAY CONTROL PANEL \\
\hline (36) SHUTTER OPEN--FLASHING LIGHT & ES-1.9-39 & RED OR MAGENTA LIGHT \\
\hline (20) SHUTTER CLOSED - -STEADY LIGHT & ES-1.9-40 & GREEN LIGHT INSTALLED ON $X$-RAY CONTROL PANEL \\
\hline (38) X-RAY OFF/SOURCE SHIELDED LIGHT & ES-1.9-41 & GREEN LIGHT INSTALLED ON X-RAY CONTROL PANEL \\
\hline \multicolumn{3}{|l|}{ AUDIBLE WARNING DEVICES } \\
\hline \multicolumn{3}{|l|}{ PHYSICAL RESTRAINTS } \\
\hline (34) PADLOCKS & ES-1.9-47 & LOCAIION OF PADLOCKS ARE DETERMINED BY OPERATIONS DEPARTMENT \\
\hline
\end{tabular}


X-RAY STORAGE FACILITIES (TYPE IB)

ES-1.9-7

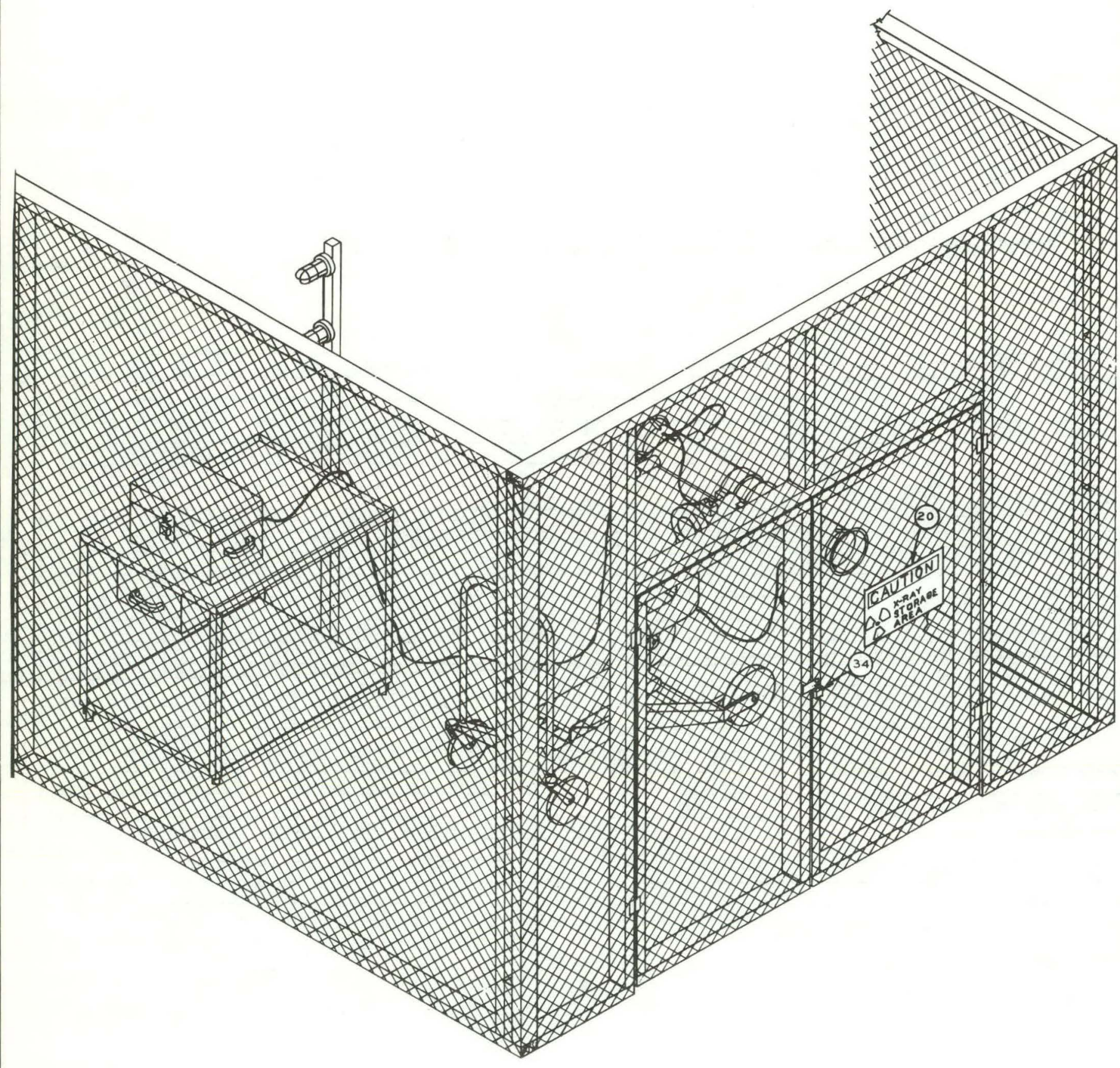

NOTE

1. NUMBERS IN CIRCLES REFER TO ITEMS LISTED

ON MATRIX ES-1.9-2. 


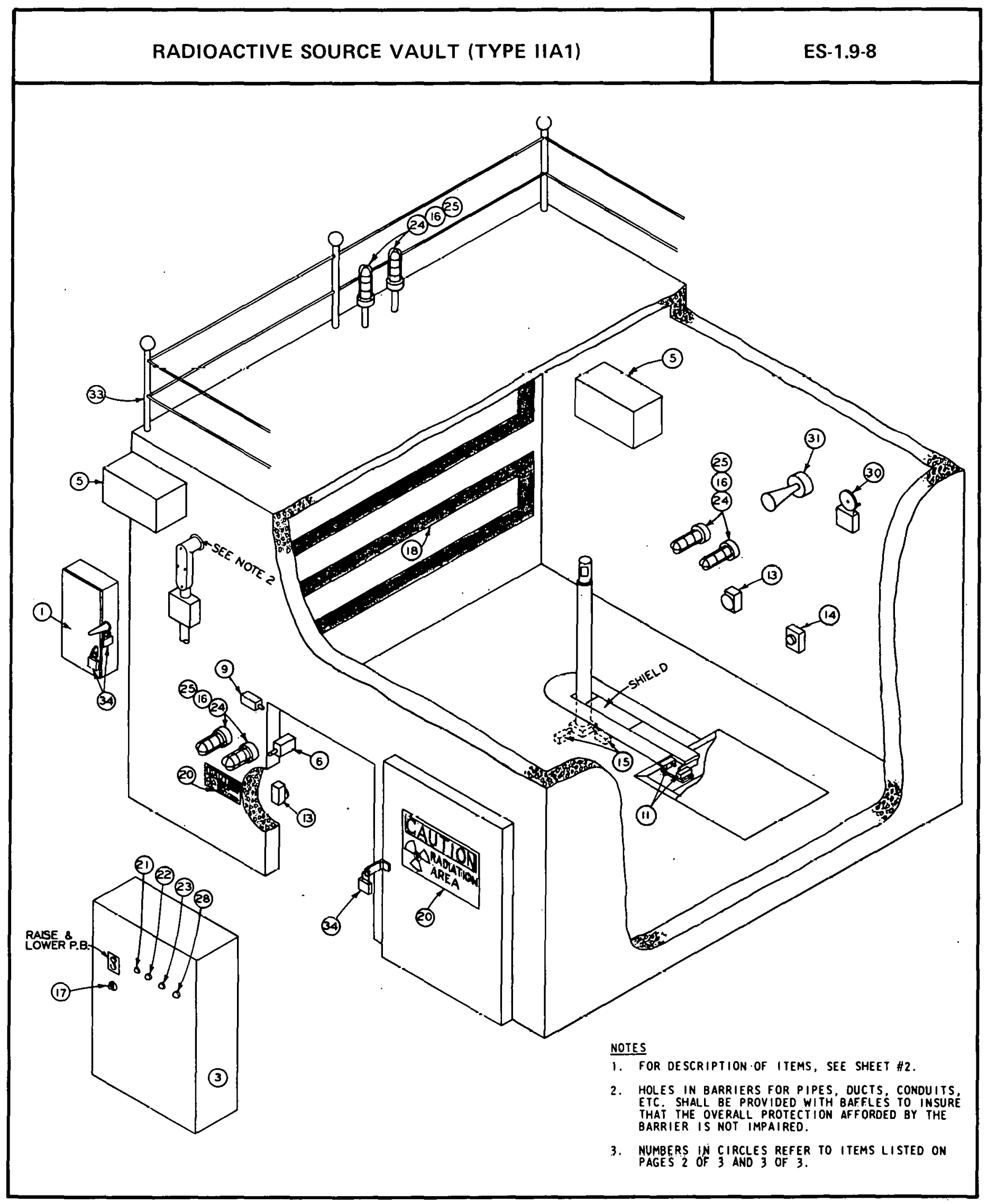


GENERAL

THIS STANDARD OUTLINES THE REQUIREMENTS FOR EQUIPPING RADIOACTIVE SOURCE VAULT FACILITIES WITH SAFETY DEVICES TO PROTECT PERSONNEL FROM HARMFUL IONIZING RADIATION.

\section{REQUIREMENTS}

IT IS REQUIRED THAT RADIOACTIVE SOURCE VAULT FACILITIES BE EOUIPPED WITH THE FOLLOWING SAFETY FEATURES THESE ITEMS ARE NOTED BY AN "X" SYMBOL ON ES-1.9-2. EXCEPTIONS FOR SPECIFIC FACILITIES WILL BE AUTHORIZED ONLY AFTER REVIEW AND CONCURRENCE OF A SAFETY FEATURES REVIEW COMMITTEE.

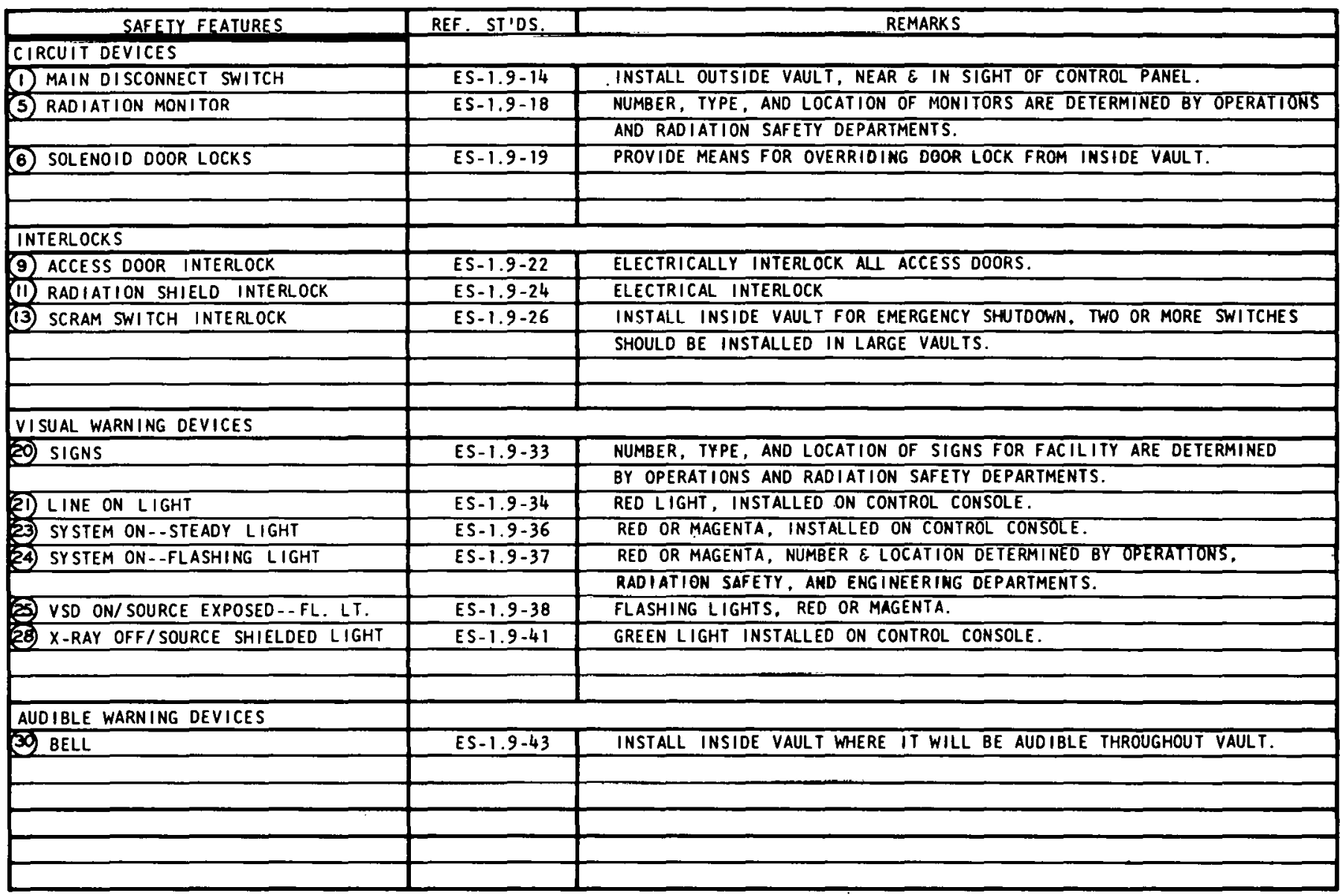


REQUIREMENTS CONT.

THE NEED FOR THE FOLLOWING SAFETY FEATURES ON EACH PARTICULAR RAD IOACTIVE SOURCE VAULT FACILITY WILL BE DETERMINED BY A SAFETY FEATURES REVIEW COMMITTEE. THESE ITEMS ARE NOTED BY AN "O" SYMBOL ON ES $-1.9-2$.

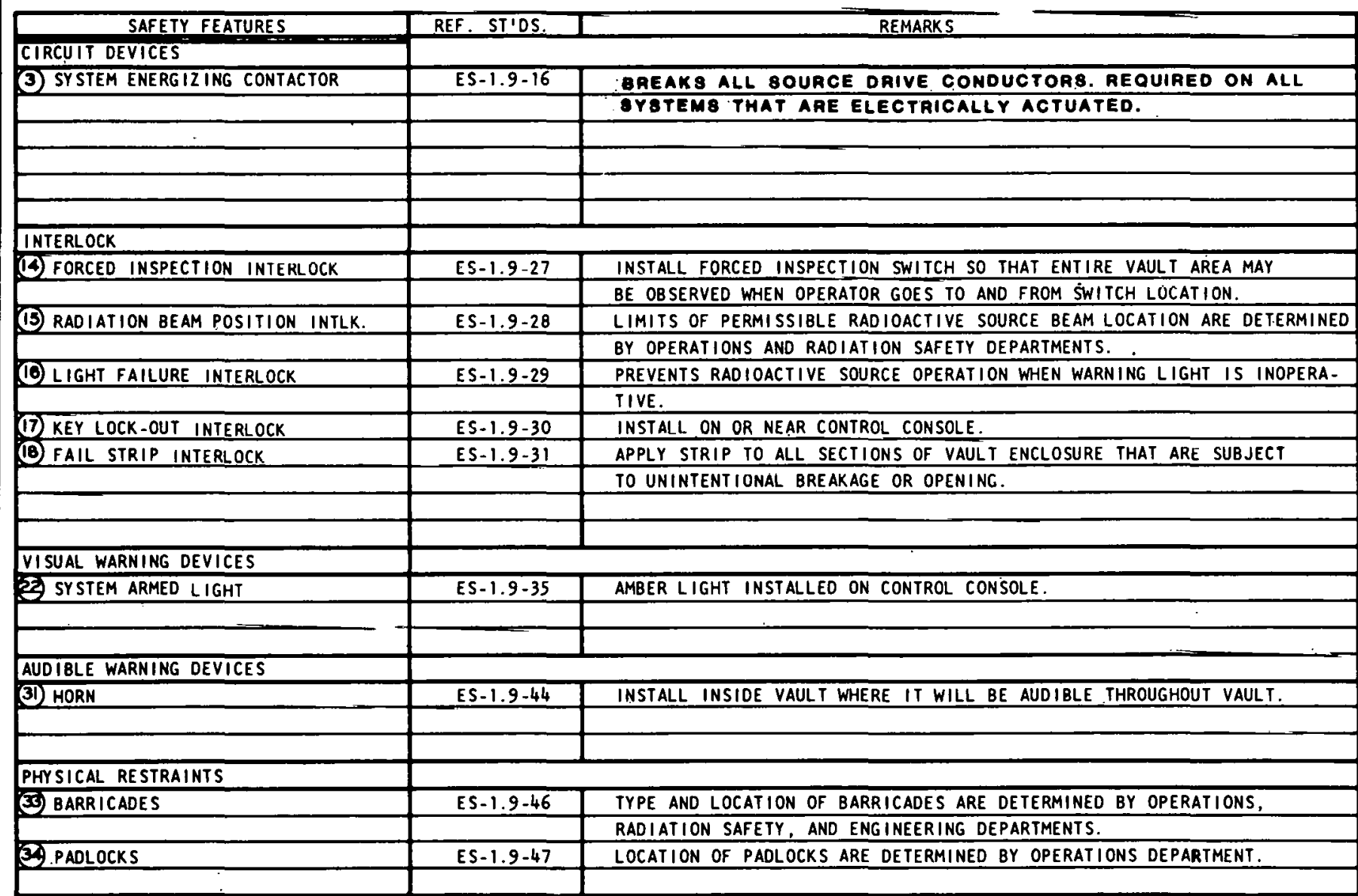


30

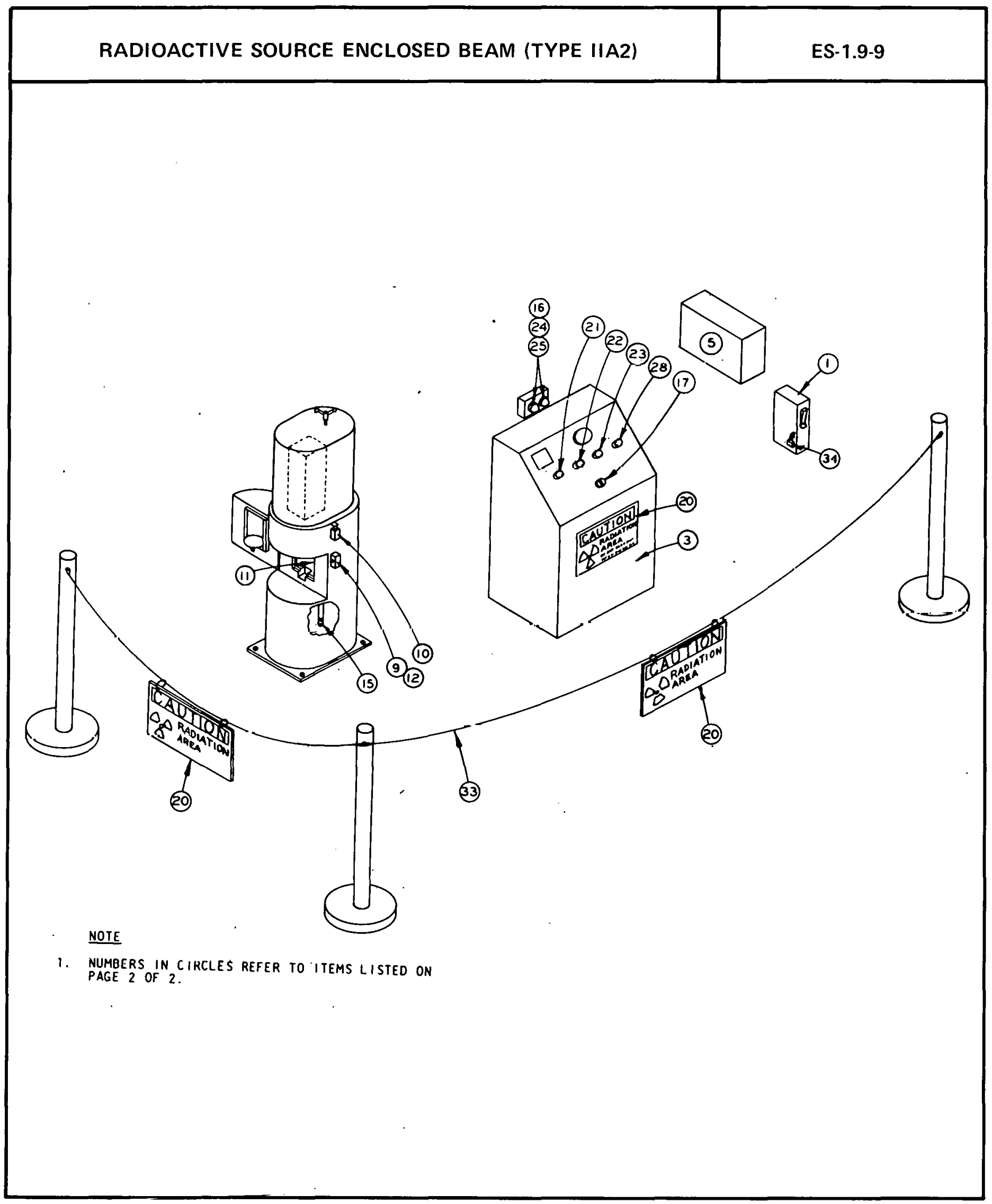


GENERAL

THIS STANDARD OUTLINES THE REQUIREMENTS FOR EQUIPPING RADIOACTIVE SOURCE ENCLOSED BEAM FACILITIES WITH SAFETY DEVICES TO PROTECT PERSONNEL FROM HARMFUL IONIZ ING RADIATION.

\section{REQUIREMENTS}

IT IS REQUIRED THAT RAD IOACTIVE SOURCE ENCLOSED BEAM FACILITIES BE EQUIPPEO WITH THE FOLLOWING SAFETY FEATURE. THIS FEATURE IS NOTED BY AN "X" SYMBOL ON ES-1.9-2. EXCEPTIONS FOR SPECIFIC FACILITIES WILL BE AUTHORIZED ONLY AFTER REVIEW AND CONCURRENCE OF A SAFETY FEATURES REVIEW COMMITTEE.

\begin{tabular}{|c|c|c|}
\hline SAFETY FEATURES & REF. ST'DS. & REMARKS \\
\hline & & OPERATIONS AND RADIATION SAFETY ULPAKTINENTS. \\
\hline
\end{tabular}

THE NEEO FOR THE FOLLOWING SAFETY FEATURES ON EACH PART ICULAR RADIOACTIVE SOURCE ENCLOSED BEAM FACILITY WILL BE DETERMINED BY A SAFETY FEATURES REVIEW COMMITTEE. THESE ITEMS ARE NOTED BY AN "0" SYMBOL ON ES-1.9-2.

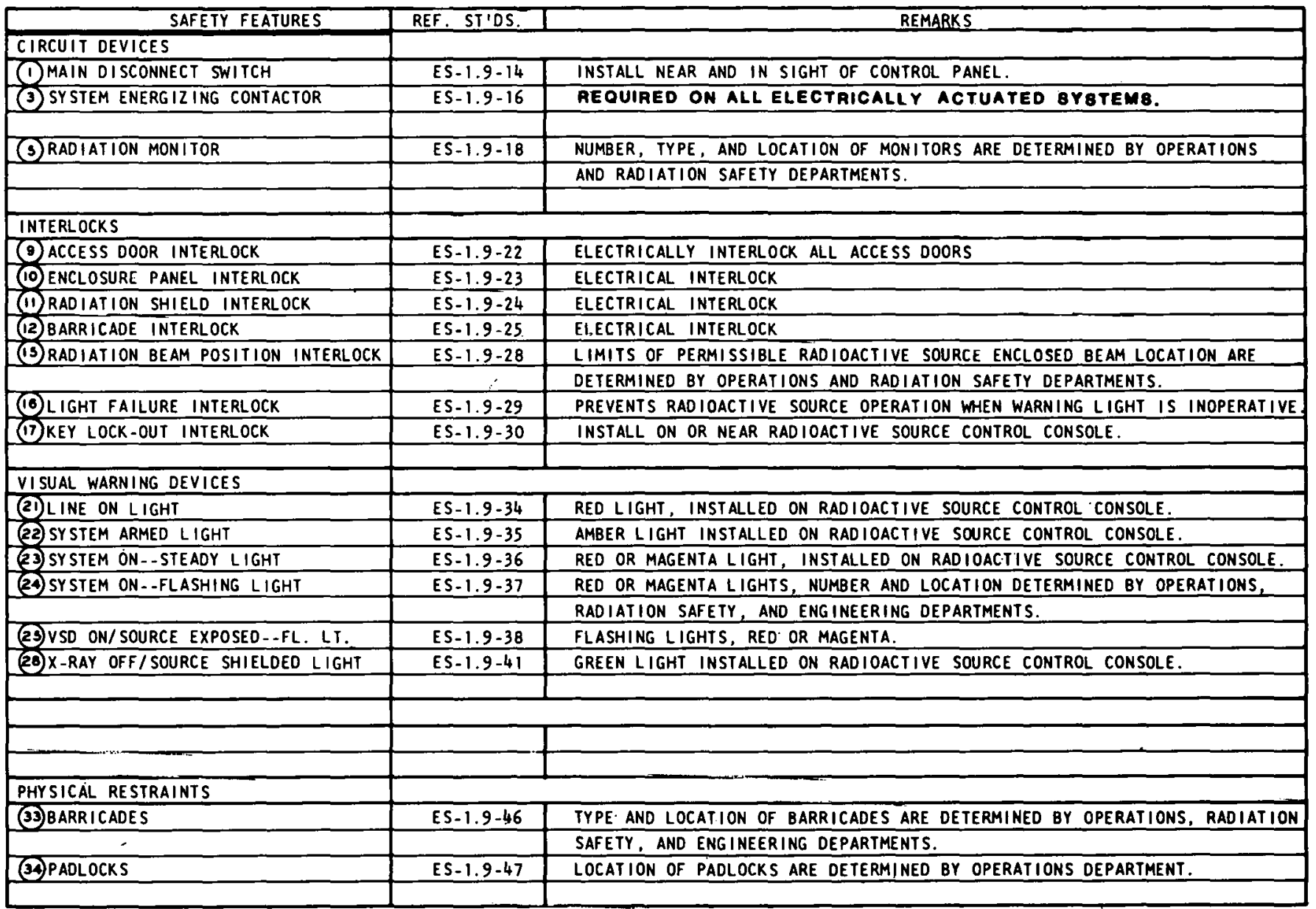




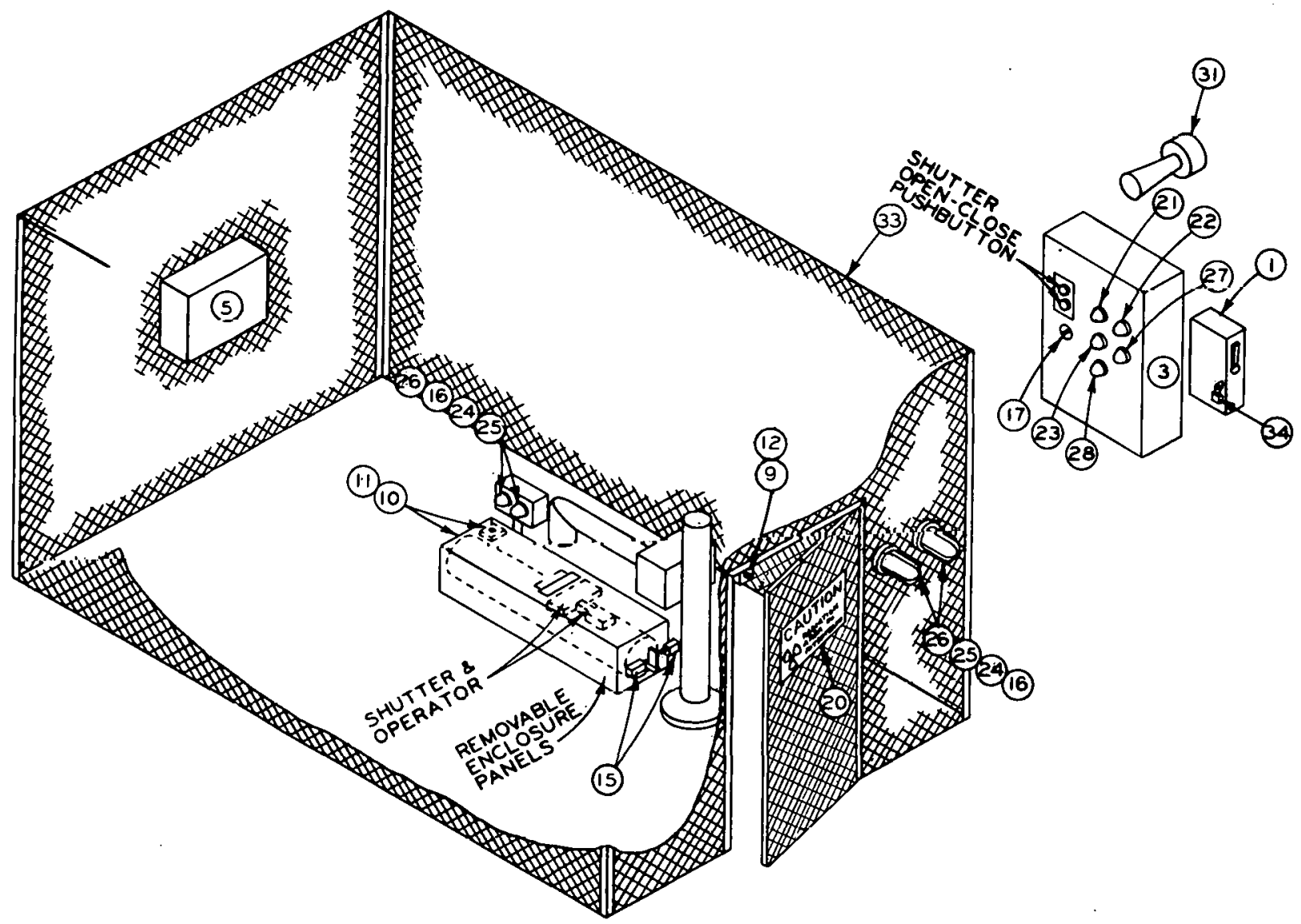

NOTE

1. NUMBERS IN CIRCLES REFER TO ITEMS LISTED

ON PAGES 2 OF 3 AND 3 OF 3.

2. DISCONNECT SWITCH AND CONTROL PANEL SHOULD BE MOUNTED ON UNISTRUT RACK ING ADJACENT TO ENCLOSURE. 
GENERAL

THIS STANDARD OUTLINES THE REQUIREMENTS FOR EQUIPPING RADIOACTIVE SOURCE OPEN BEAM FACILITIES WITH SAFETY DEVICES TO PROTECT PERSONNEL FROM HARMFUL IONIZ ING RADIATION.

REQUIREMENTS

IT IS REQUIRED THAT RADIOACTIVE SOURCE OPEN BEAM FACILITIES BE EQUIPPED WITH THE FOLLOWING SAFETY FEATURES: THESE ITEMS ARE NOTED BY AN "X" SYMBOL ON ES-1.9-2. EXCEPTIONS FOR SPECIF IC FACILITIES WILL BE AUTHORIZED ONLY AFTER REVIEW AND CONCURRENCE OF A SAFETY FEATURES REVIEW COMMITTEE.

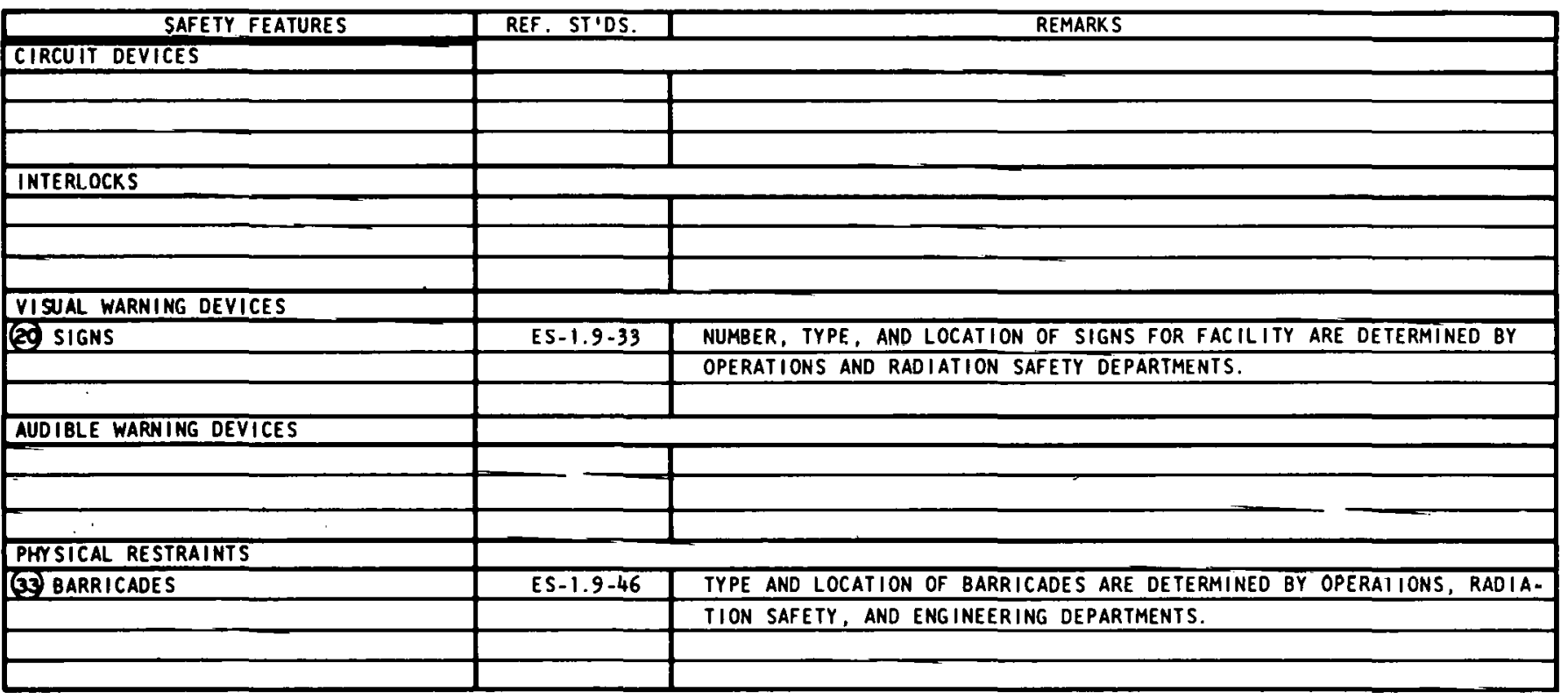


REQU IREMENIS CONT

THE NEED FOR THE FOLLOWING SAFETY FEATURES ON EACH PARTICULAR RAOIOACTIVE SOURCE OPEN BEAM FACILITY WILL BE DETERMINED BY A SAFETY FEATURES REVIEW COMMITTEE. THESE ITEMS ARE NOTED BY AN "O" SYMBOL ON ES-1.9-2.

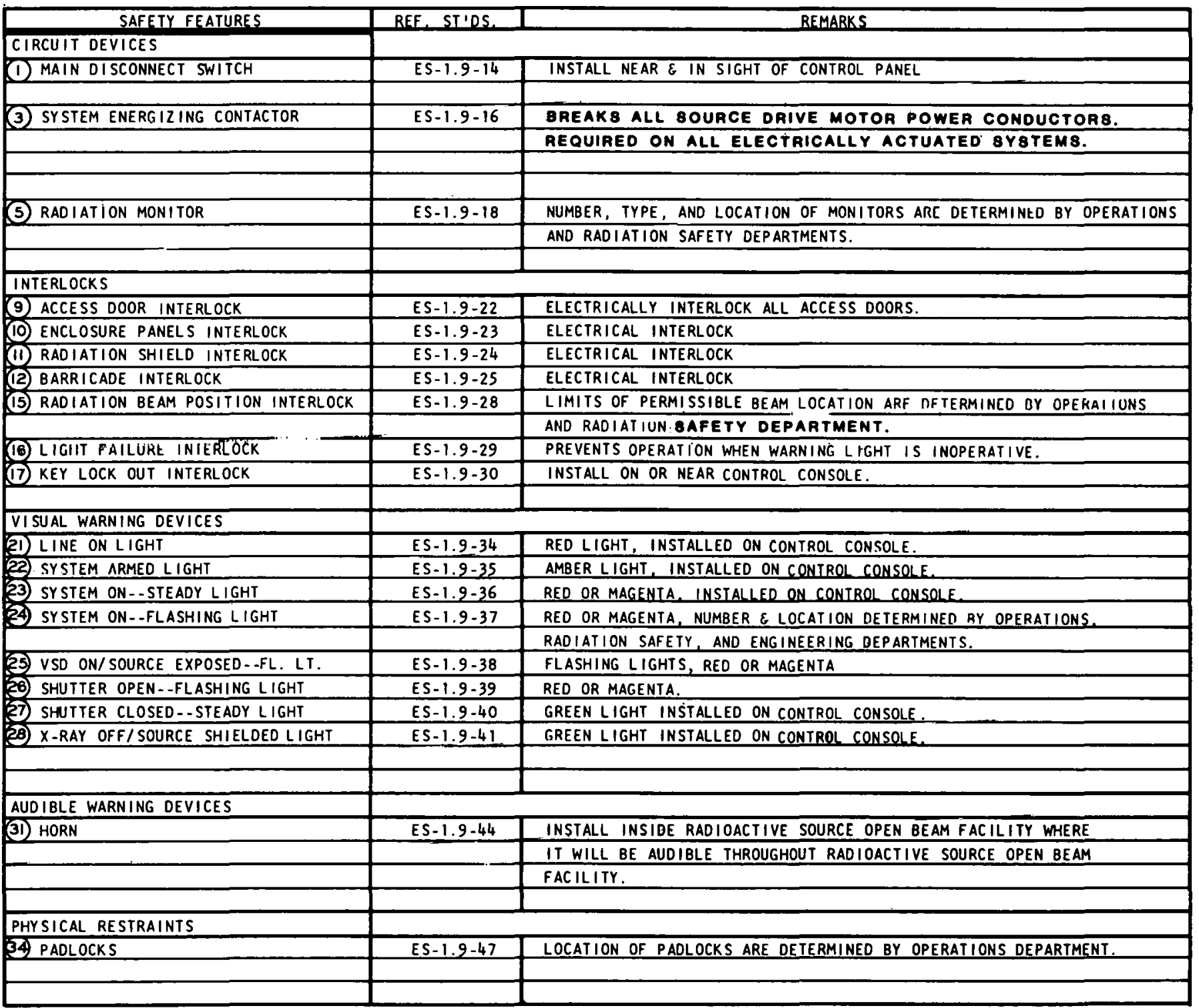




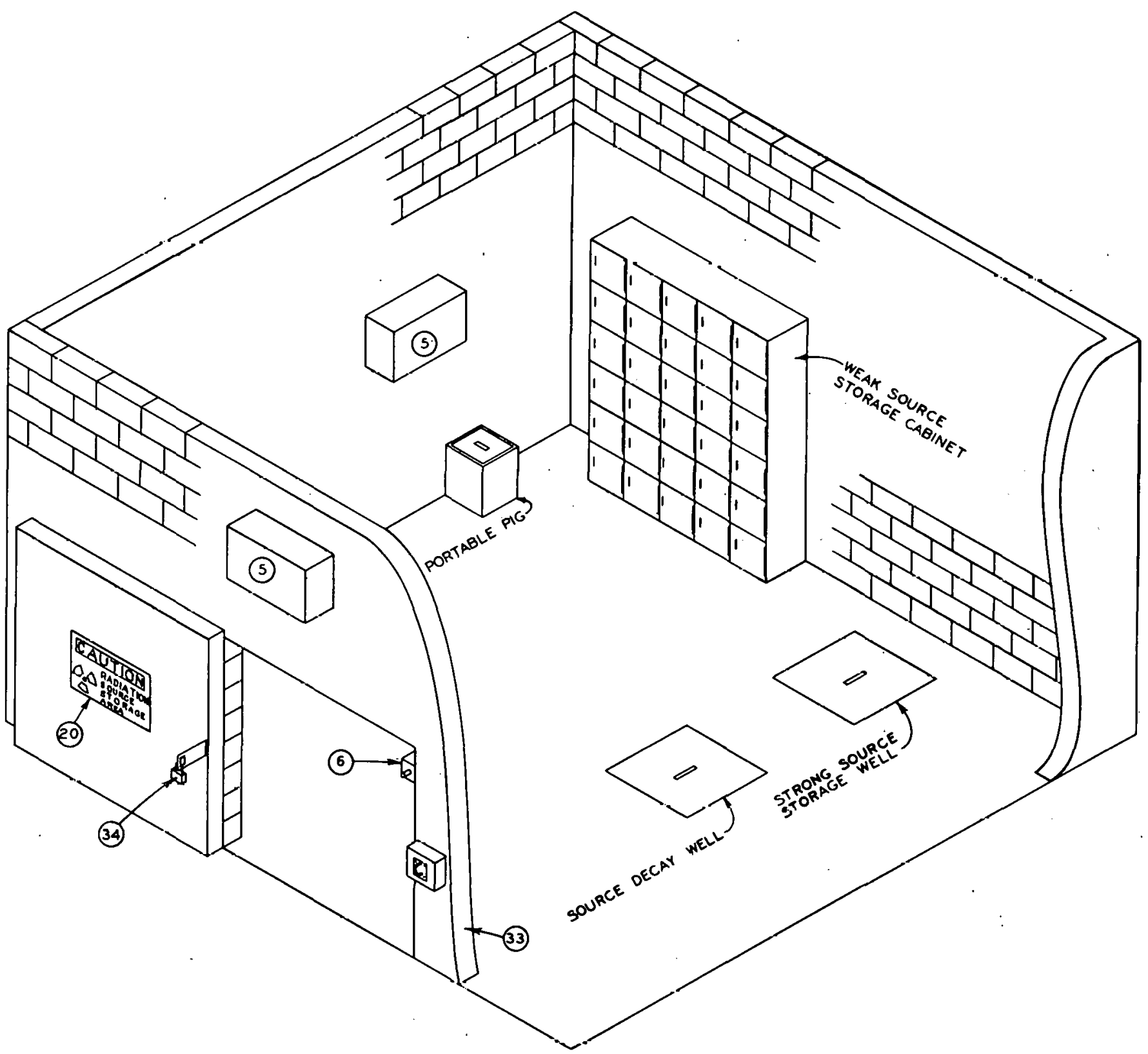

NOTE

1. NUMBERS IN CIRCLES REFER TO ITEMS LISTED

ON PAGE 2 OF 2. 
GENERAL

THIS STANDARD OUTLINES THE REQUIREMENTS FOR EQUIPPING RADIOACTIVE SOURCE STORAGE FACILITIES WITH SAFETY DEVICES TO PROTECT PERSONNEL FROM HARMFUL IONIZING RADIATION.

REQUIREMENTS

IT IS REQUI RED THAT RADIOACTIVE SOURCE STORAGE FACILITIES BE EOUIPPED WITH THE FOLLOWING SAFETY FEATURES. THESE ITEMS ARE NOTED BY AN "X" SYMBOL ON ES-1.9-2. EXCEPTIONS FOR SPECIF IC FACILITIES WILL BE AUTHORIZED ONLY AFTER REVIEW AND CONCURRENCE OF A SAFETY FEATURE S REVIEW COMMITTEE.

\begin{tabular}{|c|c|c|}
\hline SAFETY FEATURES & REF. ST'DS. & REMARKS \\
\hline \multicolumn{3}{|l|}{ VISUAL WARNING DEVICES } \\
\hline & & BY OPERATIONS AND RADIATION SAFETY DEPARTMENTS. \\
\hline \multicolumn{3}{|l|}{ PHYSICAL RESIRAINTS } \\
\hline (34) PADLOCKS & $E S-1.9-47$ & LOCKS ARE DETERMINED BY OPERATIONS OE \\
\hline
\end{tabular}

THE NEED FOR THE FOLLOWING SAFETY FEATURES ON EACH PARTICULAR RADIOACTIVE SOURCE STORAGE FACILITY WILL BE DETERMINED BY A SAFETY FEATURES REVIEW COMMITTEE. THESE ITEMS ARE NOTED BY AN "O" SYMBOL ON ES-1.9-2.

\begin{tabular}{|c|c|c|}
\hline SAFETY FEATURES & REF. ST'DS. & REMARKS \\
\hline \multicolumn{3}{|l|}{ CIRCUIT DEVICES } \\
\hline & & OPERATIONS AND RADIATION SAFETY DEPARTMENTS. \\
\hline \multicolumn{3}{|l|}{ PHYSICAL RESTRAINTS } \\
\hline (33) BARRICADES & $E S-1.9-46$ & TYPE ANO LOCATION OF BARRICADES. ARE DETERMINED BY OPERATIONS, \\
\hline
\end{tabular}




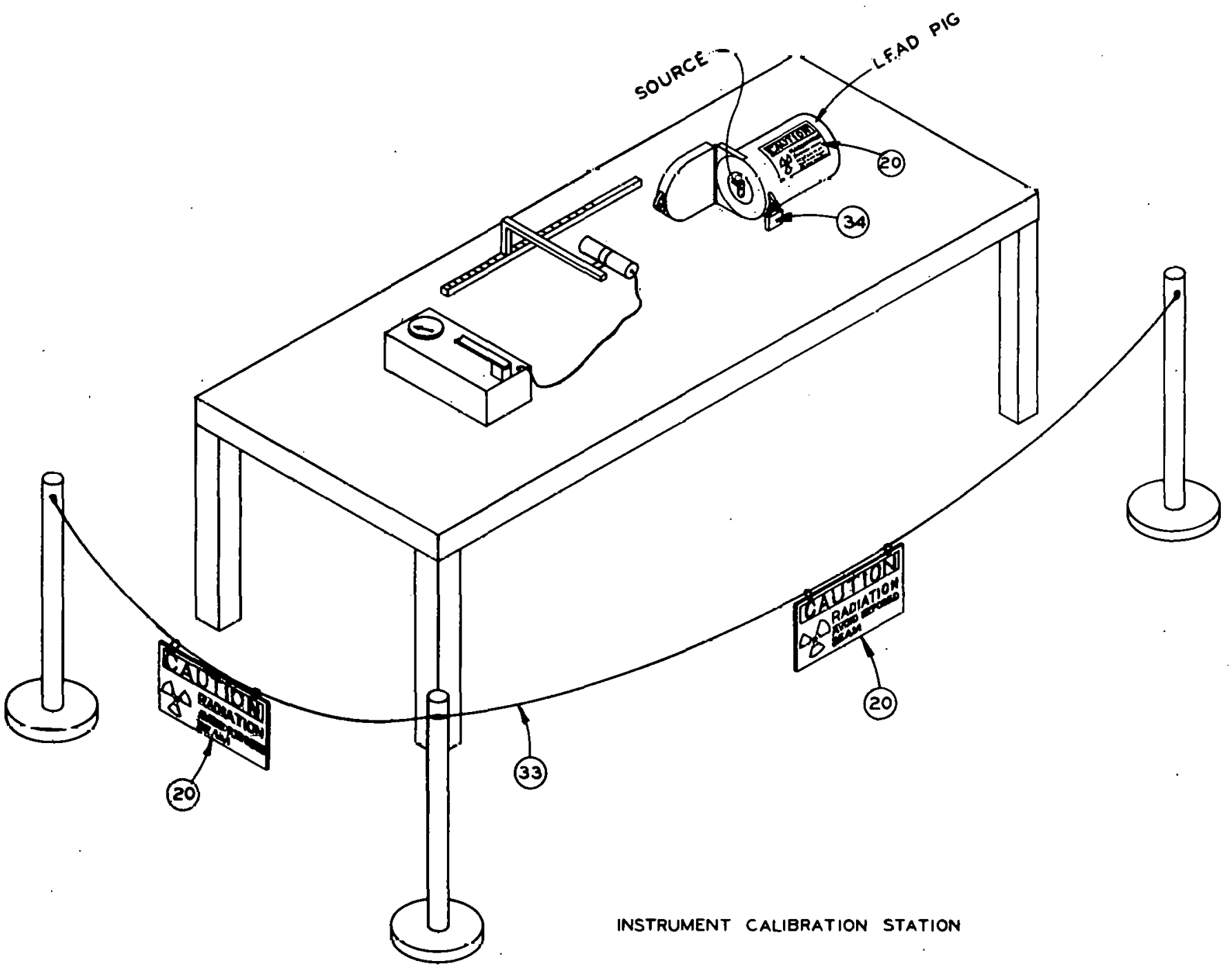

NOTE

1. NUMBERS IN CIRCLES REFER TO ITEMS LISTEO

ON ES-1.9-2. 


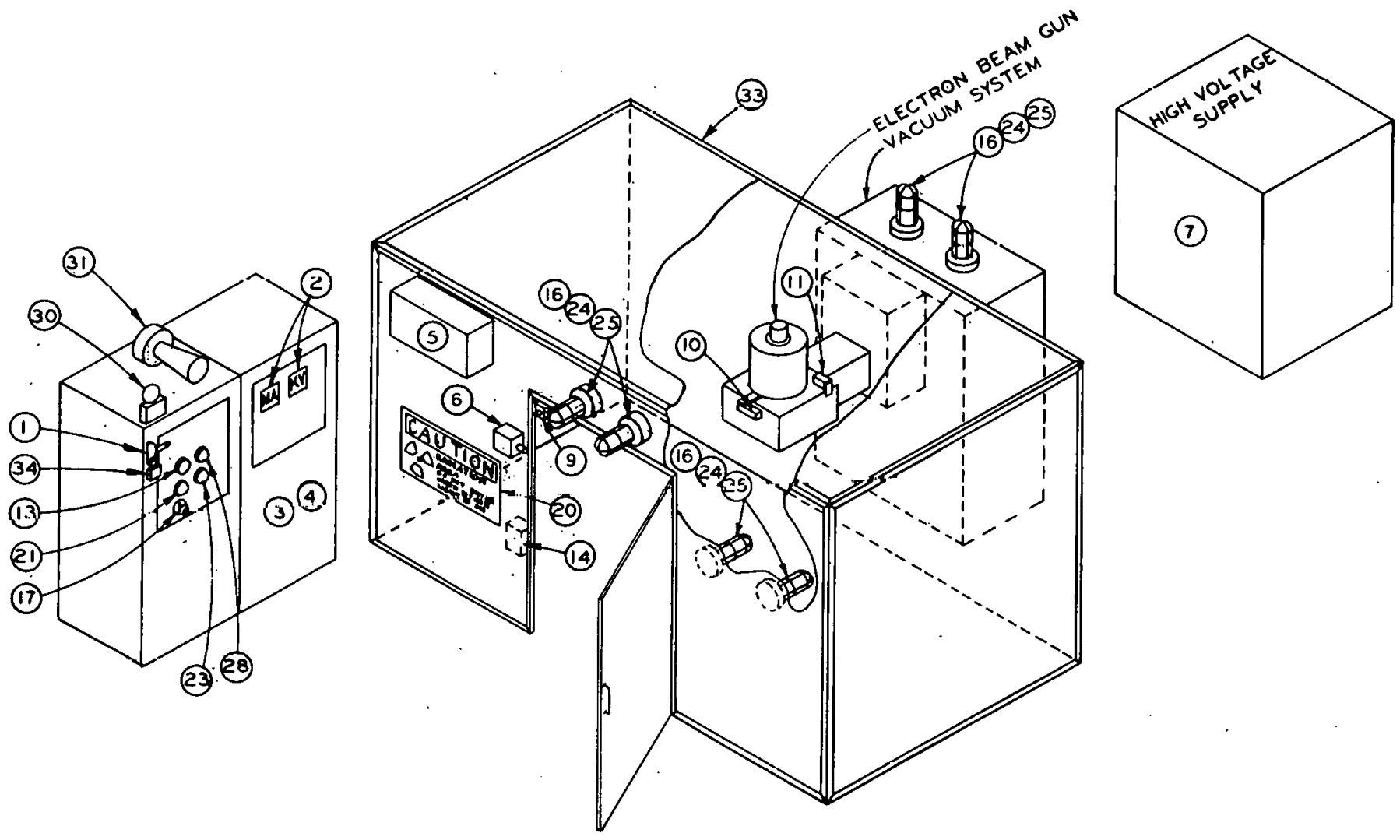

NOTE

1. NUMBERS IN CIRCLES REFER TO ITEMS LISTED ON

PAGES 2 OF 2 AND 2 OF 3. 
GEMERAL

THIS STANDARD OUTLINES THE REQUIREMENTS FOR EQUIPPING NON VACUUM ELECTRON BEAM WELDING FACILITIES WITH SAFETY DEVICES TO PROTECT. PERSONNEL FROM HARMFUL IONIZING RADIATION.

\section{REQU IREMENTS}

IT IS REQUIRED THAT NON VACUUM ELECTRON BEAM WELDING FACILITIES BE EQUIPPED WITH THE FOLLOWING SAFËYY FEAIUKE S. TIIEEE IIEMS ARE NOTEO BY AN "X" SYMBOL ON ES-1.9-2. EXCEPTIONS FOR SP.EC FF IC FACILITIES WILL BE AUTHORIZED ONLY AFTER REVIEW AND CONCURRENCE OF A SAFETY FEATURES REVIEW COMMITTEE.

\begin{tabular}{|c|c|c|}
\hline SAFETY FEATURES & REF. ST'DS. & REMARKS \\
\hline \multicolumn{3}{|l|}{ CIRCUIT DEVICES } \\
\hline (1) MAIN DISCONNECT SWITCH & ES-1.9-14 & INSTALL NEAR $\&$ IN SIGHT OF CONTROL PANEL. \\
\hline (2) MILLIAMP \& KILOVOLT METERS & ES-1.9-15 & INTEGRAL WITH CONTROL CONSOLE. \\
\hline \multirow[t]{3}{*}{ (3) SYSTEM ENERG IZING CONTACTOR } & ES-1.9-16 & MUST BREAK ALL HIGH VOLTAGE TRANSF ORMER ENERG IZING CONDUCTORS. IF \\
\hline & & OUTPUT IS 2SR /MIN. /METER, TWO CONTACTORS (REDUNDANT) SHALL BE INSTALLED \\
\hline & & TO INDEPENDENTLY BREAK ALL HIGH VOLTAGE TRANSF ORMER CONDUCTORS. \\
\hline \multirow[t]{2}{*}{ (4) VOLTAGE-SENSING DEVICE } & ES-1.9-17 & INSTALL AS NEAR TO THE HIGH VOL TAGE TRANSF ORMER AS PRACTICAL AND CONNECT \\
\hline & & DIRECTLY ACROSS THE PRIMARY LEADS OF THE TRANSFORMER. \\
\hline \multirow[t]{2}{*}{ (7) VOLTAGE TIME DECAY CONTROL } & ES-1.9-20 & MUST DISCHARGE RESIOUAL $X$-RAY POWER SUPPLY VOLTAGE BEFORE PERSONNEL \\
\hline & & CAN ENTER ENCLOSURE. \\
\hline \multicolumn{3}{|l|}{ INTERLOCKS } \\
\hline (9) ACCESS DOOR INTERLOCK & ES-1.9-22 & ELECTRICALLY INTERLOCK ALL ACCESS DOORS. \\
\hline L & & \\
\hline \multicolumn{3}{|l|}{ VISUAL WARNING OEVICES } \\
\hline \multirow[t]{2}{*}{ (20) SIGNS } & ES-1.9-33 & NUMBER, TYPE, AND LOCATION OF SIGNS FOR FACILITY ARE DETERMINED BY \\
\hline & & OPERATIONS AND RADIATION SAFETY DEPARTMENTS. \\
\hline \multirow{4}{*}{$\begin{array}{l}\text { (21) LINE ON LIGHT } \\
\text { SY STEM ON- - STEADY LIGHT } \\
\text { SYSTEM ON--FLASHING LIGHT }\end{array}$} & ES-1.9-34 & REO LIGHT, INSTALLEO ON CONTROL PANEL. \\
\hline & ES-1.9-36 & RED OR MAGENTA, INSTALLED ON CONTROL PANEL. \\
\hline & ES-1.9-37 & RED OR MAGENTA, NUMBER \& LOCATION DETERMINED BY OPERATIONS, RADIATION. \\
\hline & & SAFETY, AND ENG INEERING DEPARTMENTS. \\
\hline \multirow[t]{2}{*}{ (E) VSD ON/SOURCE EXPOSED--FL. LT. } & $E S-1.9-38$ & FLASHING LIGHTS, BED OR MAGENTA. \\
\hline & & \\
\hline \multicolumn{3}{|l|}{ AUDIBLE WARNING DEVICES } \\
\hline (30) BELL & ES-1.9-43 & INSTALL ON CONTROL PANEL. \\
\hline & & \\
\hline & & \\
\hline
\end{tabular}


REQUIREMENTS CONT.

THE NEEO FOR THE FOLLOWING SAFETY FEATURES ON EACH PARTICULAR NON VACUUM ELECTRON BEAM WELOING FACILITY WILL BE DETERMINED BY A SAFETY FEATURES REVIEW COMMITTEE. IHESE ITEMS ARE NOTED BY AN "O" SYMBOL ON ES-1.9-2.

\begin{tabular}{|c|c|c|}
\hline SAFETY FEATURES & REF. ST'DS. & REMARKS \\
\hline \multicolumn{3}{|l|}{ CIRCUIT DEVICES } \\
\hline (5) RADIATION MONITOR & $E S-1.9-18$ & NUMBER, TYPE, AND LOCATION OF MONITORS ARE DETERMINED BY OPERATIONS \\
\hline & & AND RADIATION SAFETY DEPARTMENTS. \\
\hline (6) SOLENOID DOOR LOCKS & ES-1.9-19 & PROVIOE MEANS FOR OVERRIDING DOOR LOCK FROM INSIDE VAULT \\
\hline \multicolumn{3}{|l|}{ INTERLOCKS } \\
\hline (10) ENCLOSURE PANELS INTERLOCK & ES-1.9-23 & ELECTRICALLY INTERLOCK ALL ENCLOSURE PANELS. \\
\hline (11) RADIATION SHIELD INTERLOCK & ES-1.9-24 & ELECTRICAL INTERLOCK \\
\hline (13) SCRAM SWITCH INTERLOCK & $E S-1.9-26$ & EMERGENCY SHUTDOWN SWITCH LOCATED ON CONTROL PANEL. \\
\hline (14) FORCED INSPECTION INTERLOCK & ES-1.9-27 & INSTALL FORCED INSPECTION SWITCH SO THAT ENTIRE VAULT AREA MAY BE \\
\hline & & OBSERVED NHEN OPERATOR GOES TO AND FROM SWITCH LOCATION. \\
\hline (10) LIOHT FAILURE INTERLOCK & $E$ E-1.8-20 & PREVENTS WELDER OPERATION WHEN WARNING LIOHT IS INOPERATIVE \\
\hline (17) KEY LOCKOUT INTEALOCK & ES-1.9-30 & INSTALL ON CONTROL PANEL \\
\hline \multicolumn{3}{|l|}{ VISUAL WARNING DEVICES } \\
\hline (E) X-RAY OFF/SOURCE SHIELDED LT. & ES-1.9-41 & GREEN LIGHT INSTALLED ON CONTROL PANEL. \\
\hline \multicolumn{3}{|l|}{ AUDIBLE WARNING DEVICES } \\
\hline (3) HORN & ES-1.9-44 & INSTALL ON CONTROL PANEL,. \\
\hline \multicolumn{3}{|l|}{ PHYSICAL RESTRAINTS } \\
\hline (33) BARRICADES & ES-1.9-46 & TYPE AND LOCATION OF BARRICADES ARE DETERMINED BY OPERATIONS, \\
\hline & & RADIATION SAFETY, AND ENGINEERING DEPARTMENTS. \\
\hline (3) PADLOCKS & ES-1.9-47 & LOCATION OF PADLOCKS ARE DETERMINED BY OPERATIONS DEPARTMENT. \\
\hline
\end{tabular}


GENERAL

A MAIN DISCONNECT SWITCH IS AN ELECTRICAL SAFETY SWITCH OR OTHER MANUALLY-OPERATED DEVICE TO BREAK ALL INPUT POWER (HOT) CONDUCTORS TO A RADIATION-PRODUCING SYSTEM. THIS SAFETY FEATURE IS REQUIRED ON ALL ELECTRICAL SYSTEMS.

THE SWITCH SHALL BE LOCATED SO AS TO BE READILY ACCESSIBLE FROM THE SYSTEM CONTROL PANEL OR CONSOLE. IF AUXILIARY POWER SOURCES ARE REQUIRED, THEY SHALL BE DE-ENERGIZED THROUGH USE OF AUXILIARY CONTACTS ON THE MAIN SWITCH.

IN CASES WHERE PORTABLE UNITS WITH POWER CORDS PLUG INTO A RECEPTACLE, THE PLUG CAN BE USED AS THE MAIN DISCONNECT.

\section{DESCRIPTION}

SAFETY SWITCHES THAT COMPLY WITH REQUIREMENTS OF THIS STANDARD ARE SHOWN IN THE FOLLOWING EXAMPLES. REFERENCE TO MATERIAL OR EQU IPMENT BY BRAND NAME, CATALOG NUMBER OR NAME OF MANUFACTURER IS INTENDED TO BE DESCRIPTIVE, NOT RESTRICTIVE, AND IS SOLLLY +UK IHE PURPUSE ÓF INO ICATING TYPE OR QUALITY OF ITEM THAT IS ASTFPTARI F.

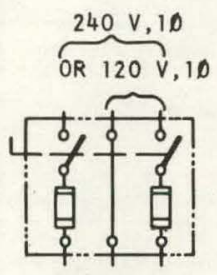

FIGURE 1 2 POLE FUSIBLE
SAFETY SWITCH WITH SOL ID NEUTRAL TYPE A-87312 OR EQUAL.

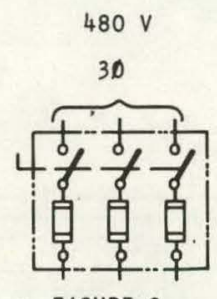

FIGURE 2

3 POLE FUSIBLE SAFETY SWITCH, SQUARE "D" CO. TYPE A-86343 OR EQUAL.

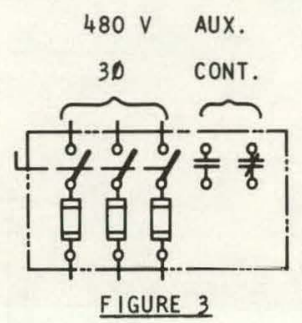

3 POLE FUSIBLE SAFETY SWI TCH WITH AUXILI ARY CONTACTS, SQUARE "D" CO. TYPE' H3OO SERIES OR EQUAL.

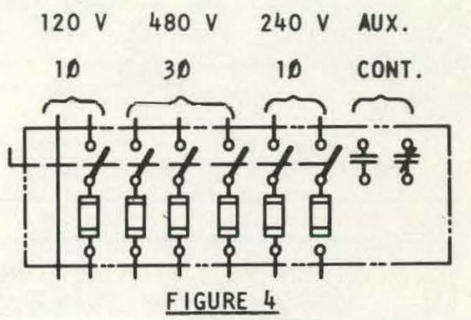

6 POLE FUSIBLE SAFETY SWITCH WITH AUXILIARY CONTACTS, SQUARE "D" CO. TYPE H80000 SERIES OR EQUAL.

BLOCK DIAGRAMS OF TYPICAL SYSTEMS

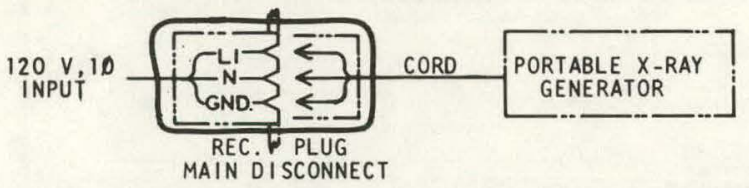

FIGURE 5

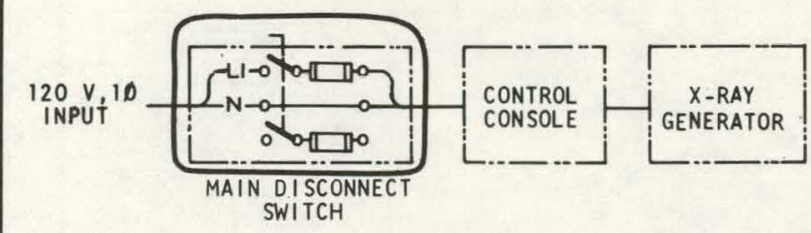

FIGURE 6

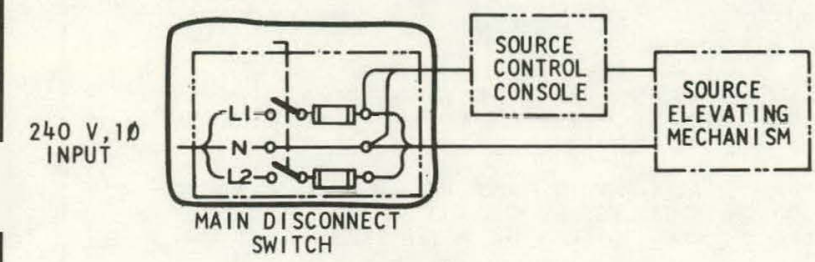

FIGURE 7

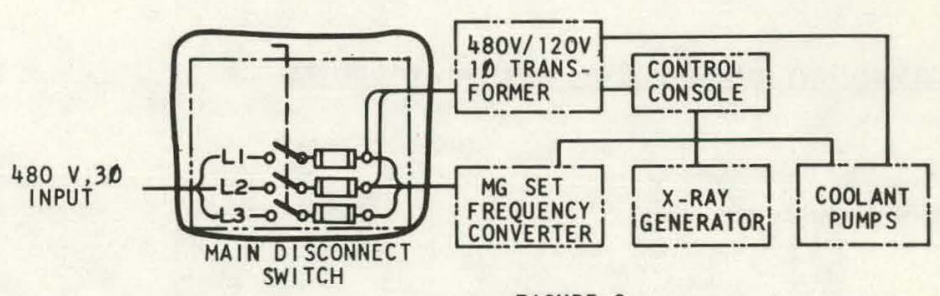

FIGURE 8

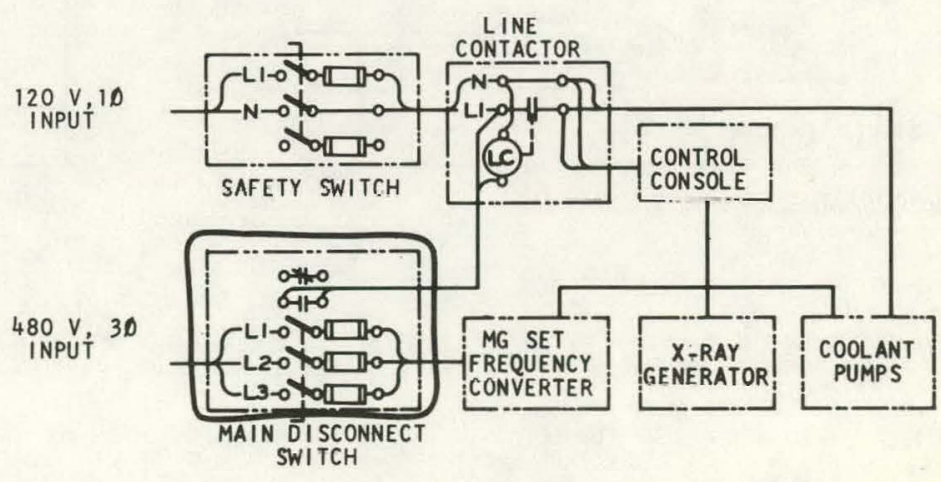

FIGURE 9 


\section{GENERAL}

MILL I AMP AND KILOVOLT METERS ARE CONTROL -PANEL MOUNTED ELECTRICAL METERS USED TO INDICATE OUTPUT CURRENT AND VOLTAGE OF AN $X$-RAY GENERATING SY STEM.

THE METERS MAY BE CONNECTED IN THE HIGH-VOLTAGE CIRCUIT TO INDICATE X-RAY GENERATOR CURRENT AND VOLTAGE DIRECTLY, OR THEY MAY BE CONNECTED IN THE PRIMARY. SIDE OF THE X-RAY TRANSFORMER AND CALIBRATED IN SECONDARY KILOVOLTS AND MILLIAMPS ACCORD INGLY.

MILLI AMP AND KILOVOLT METERS ARE NORMALLY SPECIFIED TO BE PART OF VENDOR-SUPPLIED EQUIPMENT.

\section{DESCRIPTION}

THE MILLI AMP AND KILOVOLT METERS MAY HAVE ROUND OR RECTANGULAR TYPE SCALES, LARGE ENOUGH TO BE EASILY READ. THEY SHOULD BE INSTALLED IN A POSITION FOR CONVENIENT VIEWING BY AN OPERATOR AT THE X-RAY CONTROL STATION. THE KILOVOLT METER SHOULD BE INSTALLED NEAR THE KILOVOLT-CONTROL SWITCH AND THE MILLIAMP METER SHOULD BE INSTALLED NEAR THE MILLI IAMP-CONTROL

SWITCH. EXAMPLES OF METER CONF IGURATIONS AND LOCATIONS THAT COMPLY WITH THESE REQUIREMENTS ARE SHOWN IN FIGURES 1 AND 2.

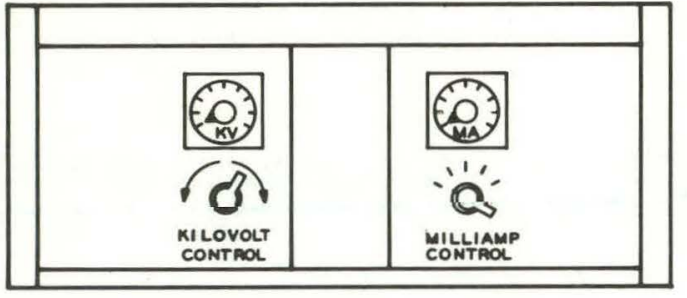

FIG. I

SAMPLE CONTROL PANEL

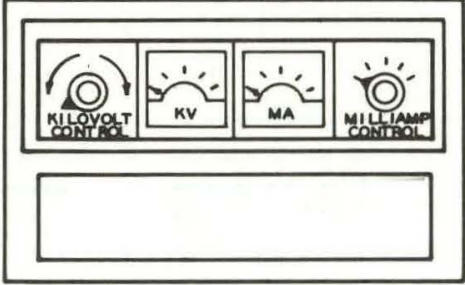

FIG. 2

SAMPLE CONTROL PANEL

ELEMENTARY DIAGRAMS OF TYPICAL CIRCUITS

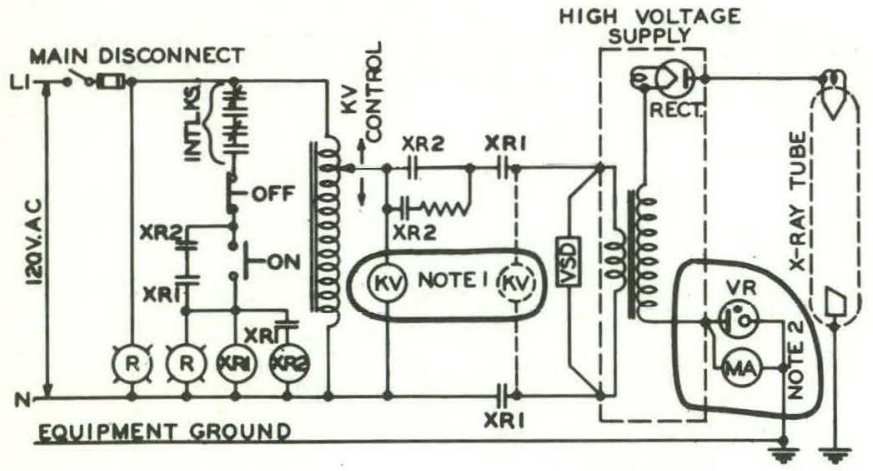

FIG. 3

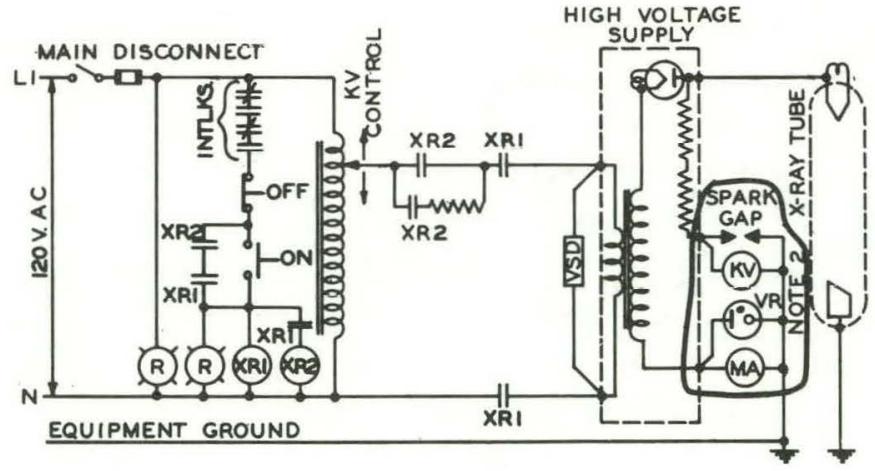

FIG. 4

NOTE 1 - WHEN THE KILOVOLT METER IS CONNECTED IN THE PRIMARY OF THE HIGH-VOLTAGE SUPPLY, AS SHOWN IN FIGURE 3 , IT MAY BE CONNECTED IN THE CIRCUIT BEFORE, OR AFTER, THE X-RAY CONTACTORS DEPENDING ON PREFERENCE OF THE X-RAY' OPERATING GROUP.

NOTE 2 - WHEN METERS ARE CONNECTED IN THE SECONDARY OF THE HIGH-VOLTAGE SUPPLY, AS SHOWN IN FIGURES 3 AND 4 , VOLTAGE ON METER CIRCUITS EXTERNAL TO THE POWER SUPPLY MUST BE LIMITED TO 300 VOL TS OR LESS BY MEANS OF SPARK GAPS, COLD CATHODE GAS-FILLED TUBES, OR OTHER SUITABLE VOLTAGE-LIMITING DEVICES CONNECTED FROM THE METER TERMINAL AT THE HIGH-VOLTAGE TANK TO EQUIPMENT GROUND. 


\section{(3) SYSTEM ENERGIZING CONTACTOR(S)}

ES-1.9-16

GENERAL

SYSTEM ENERG IZ ING CONTACTORS ARE ELECTRICAL CONTACTORS USED TO BREAK ALL SOURCE DRIVE OR HIGH VOLTAGE PRIMARY CONDUCTORS. ACTUATION OF THE CONJACTORS SHALL BE THE LAST STEP IN ENERGIZ ING A SYSTEM FOR X-RAY GENERATION OR SOURCE EXPOSURE.

IF AN EXISTING SYSTEM DOES NOT HAVE ALL SYSTEM ENERGIZING CONDUCTORS BROKEN, AN ADDITIONAL CONTACTOR MUST BE ADDED WHICH WILL BREAK ALL SYSTEM ENERG IZ ING CONDUCTORS, INCLUD ING THE ONES ALREADY BROKEN. THE ADDITIONAL CONTACTOR SHALL BE ENERG IZED BEFORE THE EXISTING SYSTEM ENERG IŻ ING CONTACTOR SO THAT REDUCED VOLTAGE SYSTEM ENERG IZING FEATURES OF THE SYSTEM ARE RETAINED. REDUNDANT CONTACTORS SHALL BE PROVIDED ON ALL SYSTEMS EOUAL TO OR ABOVE IOOR/MIN./METER DOSAGE RATING.

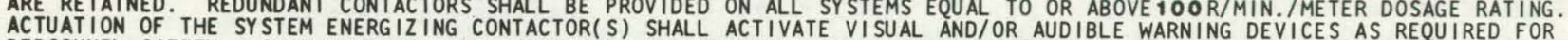
PERSONNEL SAFETY. SYSTEM ENERGIZING CONTACTORS ARE REQUIRED ON ALL SYSTEMS THAT ARE ELECTRICALLY ACTUATED.

UESLKIPIIUNN

SYSTEM ENERGIZING CONTACTORS THAT COMPLY WITH THE REQUIREMENTS OF THIS STANDARD ARE SHOWN IN THE FOLLOWING EXAMPLES. REFERENCE TO MATERIAL OR EQUIPMENT BY BRAND NAME, CATALOG NUMBER, OR NAME OF MANUFACTURER IS INTENDED TO BE DESCRIPTIVE, NOT RESTRICTIVE, AND IS SOLELY FOR THE PURPOSE OF INDICATING THE' QUALITY OF ITEM THAT IS ACCEPTABLE.

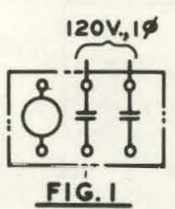

MAGNETIC CONTAC TOR, 2 POLE, 15 AMP, ALLEN -

BRADLEY CO. TYPE 702 SERIES

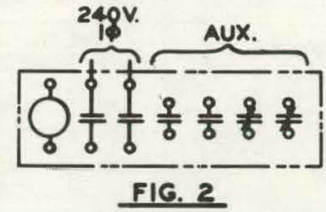

MAGNETIC CONTACTOR 2 POLE, 25 AMPS, CO. TYPE CR105KO02

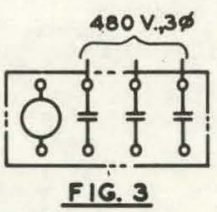

MAGNETIC CONTACTOR, 3 POLE: SIZE 1 GENERAL ELECTRIC CO. TYPE CR 105 CO02

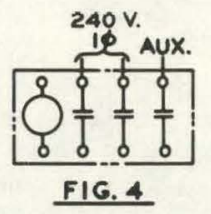

MERCURY PLUNGER CONTACTOR, 3 POLE, EBERT CO.' TYPE A-111 (FOR SILENT OPERATION)

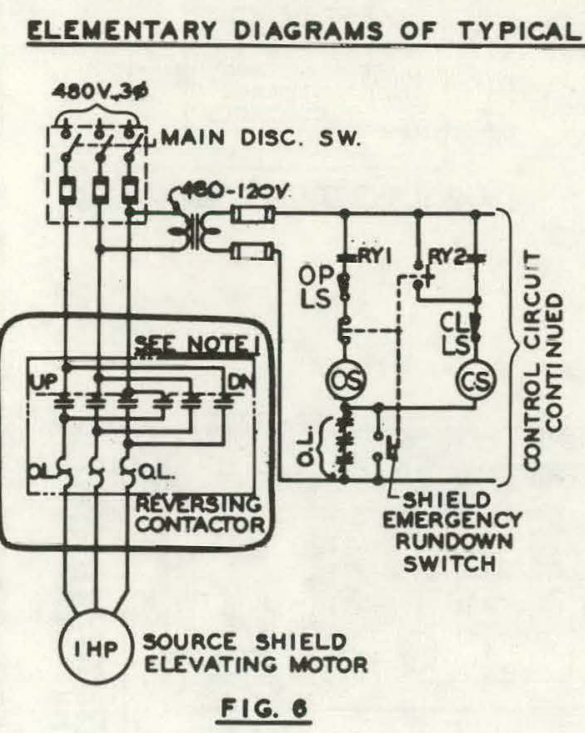

NOTE 1: REVERSING CONTACTOR BREAKS ALL HOT CONDUCTORS TO SOURCE SHIELD ELEVATING MOTOR.

NOTE 2: XRI CONTACTOR ADDED TO BREAK BOTH SIDES OF HV TRANSFORMER PRI.

NOTE 3: CONTACTOR XR2 ADDED FOR HV TRANSFORMER DE-ENERG IZ ING REDUNDANCY.
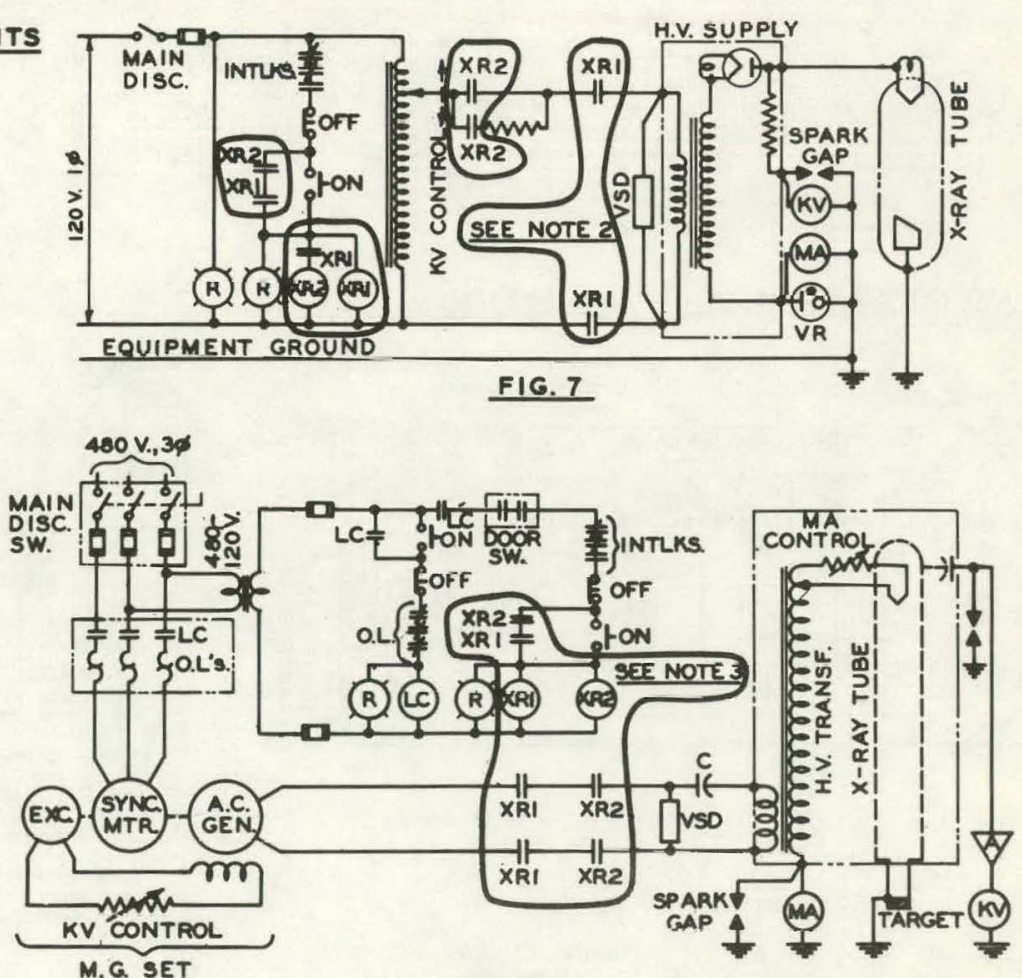

FIG 8

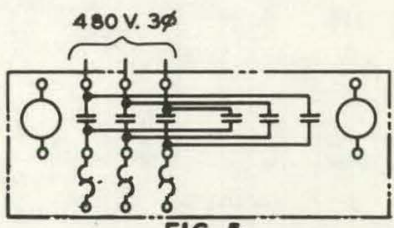

MAGNETIC REVERSIING CONTACTOR, 30, SIZE 00, ALLEN-BRADLEY CÓ. 30, SIZE 00, ALLEN-BRA
TYPE 705 -TAB SERIES.

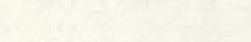

IRCUITS 
GENERAL

A VOLTAGE-SENSING DEVICE IS AN ELECTRICAL AND/OR ELECTRONIC DEVICE TO DETECT 10 VOLTS OR MORE IMPRESSED ON THE PRIMARY OF THE HIGH-VOLTAGE TRANSFORMER IN AN X-RAY GENERATING SYSTEM.

THE DEVICE SHALL BE INSTALLED DIRECTLY ACROSS THE HIGH-VOLTAGE TRANSFORMER PRIMARY, EXCEPT IN SPECIAL CASES WHERE SUCH INSTALLATION INTERFERES WITH NORMAL OPERATION OF THE MACHINE; FOR EXAMPLE, LOW POWER MACHINES SUCH AS SOME DXT GAGES EMPLOY ING HIGH FREQUENCIES IN X-RAY GENERATION. ACTUATION OF THE VOLTAGE-SENSING DEVICE SHALL ACTIVATE VISUAL AND/OR AUDIBLE WARNING DEVICES AS REQUIRED FOR PERSONNEL SAFETY. DEENERGIZATION OF THE SYSTEM ENERGIZING CONTACTOR SHALL ELECTRICALLY I SOLATE THE VOLTAGE-SENSING DEVICE FROM THE NORMAL SYSTEM SUPPLY VOLTAGE.

\section{DESCRIPTION}

CIRCUITS AND COMPONENTS FOR A VOLTAGE-SENSING DEVICE THAT COMPLIES WITH REQUIREMENTS FOR THIS STANDARD ARE SHOWN IN THE FOLLOWING FIGURES. THIS DEVICE WILL OPERATE OVER A RANGE OF 10 TO 500 VOLTS ON A HIGH VOLTAGE TRANSFORMER PRIMARY. REFERENCE TO MATERIAL OR EQUIPMENT BY BRAND NAME, CATALOG NUMBER OR NAME OF MANUFACTURER IS INTENDED TO BE DESCRIPTIVE, NOT RESTRICTIVE, AND IS SOLELY FOR THE PURPOSE OF INDICATING TYPE OR QUALITY OF ITEM THAT IS ACCEPTABLE.

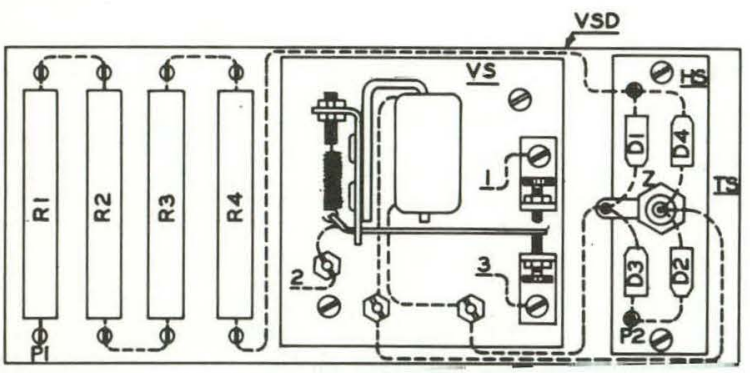

FIG. I PLAN VIEW

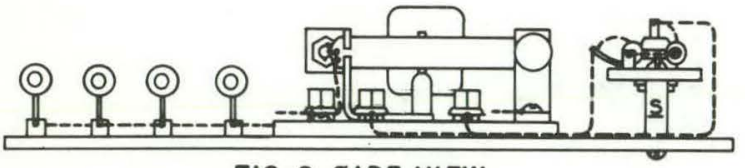

FIG. 2 SIDE VIEW

---INDICATES WIRING
COMPONENT IDENTIFICATION

D1, D2, D3 2 D4- 500 MA, 500 VOL'T, SILICON DIODES, TYPE IN2071.

HS--HEAT SINK, $1 " \times 3 " \times 1 / 8 "$ ALUMINUM.

VS--RELAY SENSITIVE, 5.17 VOLT DC, 2.65 MA, $1950 \Omega$ WARD LEONARD CO.' TYPE 250 - 38 .

$R 1, R 2, R 3, R 4--500 \Omega, 25$ WATT WIREWOUND RESISTORS, MALLORY 6Q. TYPE 2.5 IIJ.

S--STANDOFF INSULATOR, 1" $\times 3 / 4^{\prime \prime}$, TAPPED FOR 6-32 SCREW.

TS--TERMINAL STRIP, CAMBRIDGE THERMONIC CORP. NO'. ES1106.

$Z-5.6$ VOLT, 10 WATT ZENER DIODE, GENERAL INSTRUMENT CORPORATION TYPE IN1601

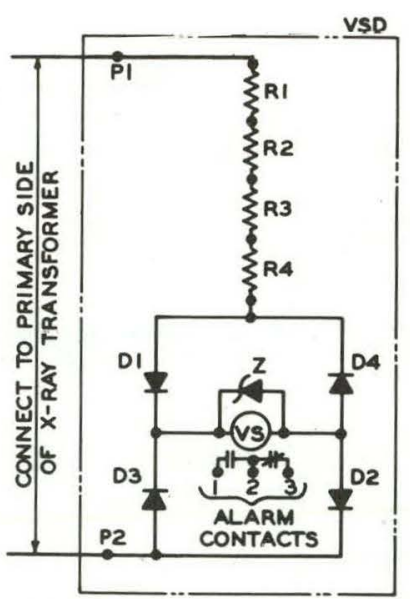

FIG. 3 ELECTRICAL SCHEMATIC

\section{ELEMENTARY DIAGRAMS OF TYPICAL SYSTEMS}

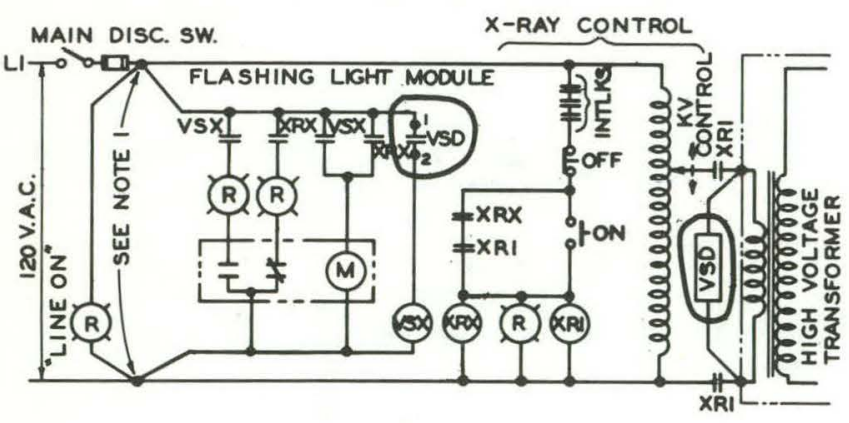

FIG. 4

NOTE 1 -- CONNECT FLASHING LIGHT MODULE TO LOAD SIDE OF MAIN DISCONNECT SWITCH.

NOTE 2 -- CONNECT FLASHING LIGHT MODULE TO LOAD SIDE OF CONTROL SWITCH.

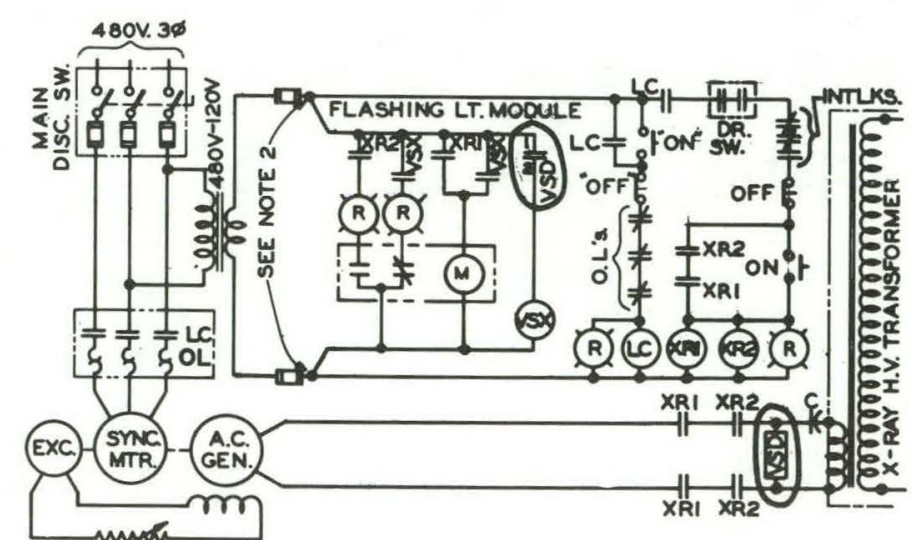

FIG.S 


\section{(5) RADIATION MONITOR}

ES-1.9-18

GENERAL

A RADIATION MONITOR IS AN ELECTRONIC DEVICE USED TO DETECT PRESENCE OF X-RAY AND/OR NUCLEAR RADIATION.

THE RADIATION MONITOR SHALL BE A PERMANENTLY MOUNTED INTEGRAL PART OF THE SYSTEM PROTECTION SETUP AND SHALL ACTIVATE VISUAL AND/OR AUDIBLE WARNING DEVICES AS REQUIRED FOR PERSONNEL SAFETY RADIATION NONITOR(S) SHALL BE PROVIDED WHERE AN X-RAY MACHINE DOSAGE RATING. IS 25R/MIN/METER OR ABOVE.

\section{DESCRIPTION}

RADIATION MONITORS THAT COMPLY WITH THIS STANDARD ARE SHOWN IN THE FOLLOWING EXAMPLES. REFERENCE TO MATERIAL OR EQU IPMENT BY BRAND NAME OR MANUFACTURER IS INTENDED TO BE DESCRIPTIVE, NOT RESTRICTIVE, AND IS SOLELY FOR THE PURPOSE OF INDICATING TYPE OR QUALITY OF ITEM THAT IS ACCEPTADLE.

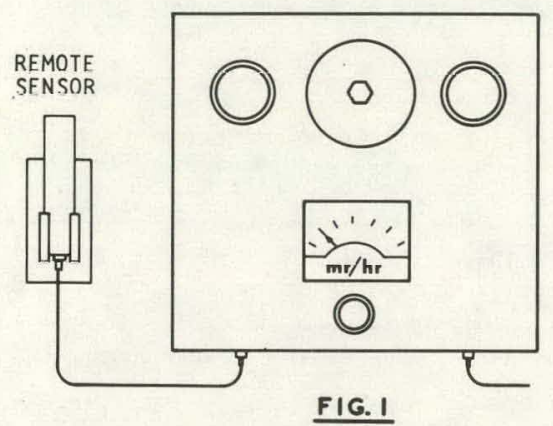

AREA RADIATION MONITOR, NUCLEAR MEASUREMENTS CORP. TYPE GA-2T.

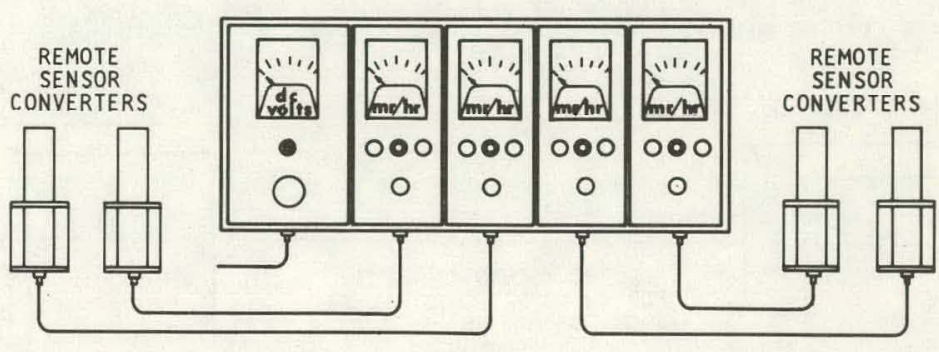

FIG. 2 .

AREA RADIATION MONITOR, REMOTE INDICATING, VICTOREEN CORPORATION SERIES $700^{\prime}$ MODEL; ALSO, GENERAL ELECTRIC CORPORATION SERIES NF10 ARM MODEL AND NUCLEAR MEASUREMENTS CORPORATION TYPE GA-2 WITH REMOTE PANEL.

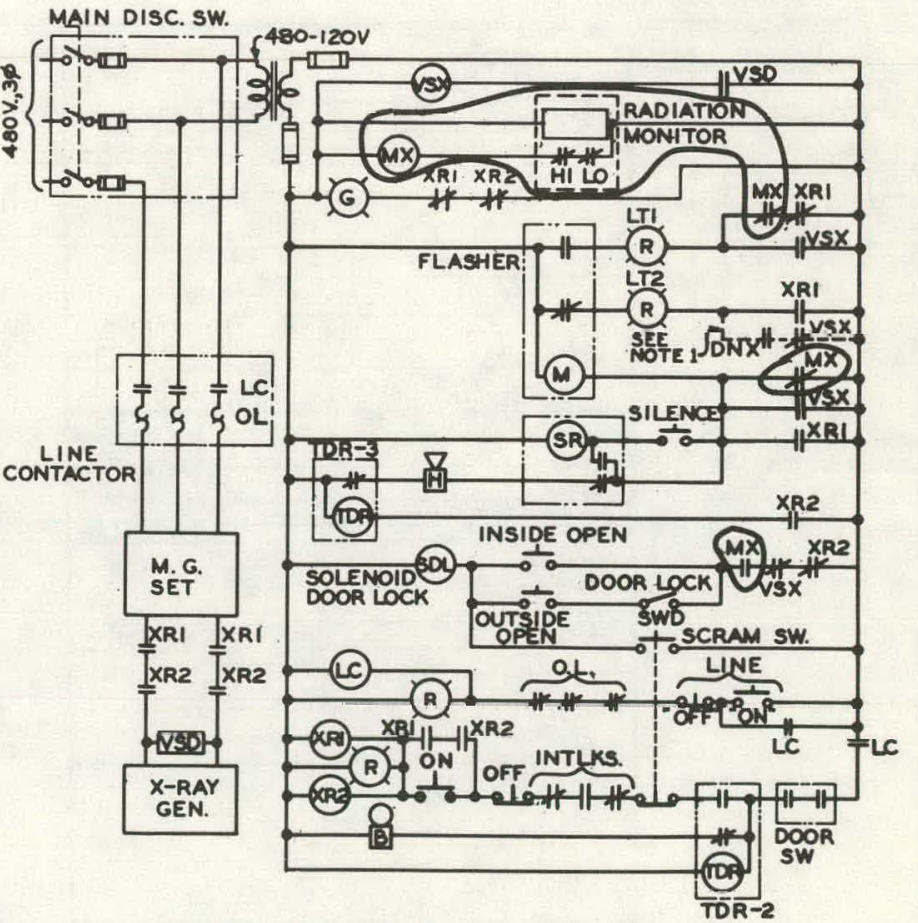

NOTES:

F1G. 4

1. ADD CIRCUIT IN DASHED LINES WHEN NUCLEAR SOURCE IS INSTALLED IN SAME FACILITY AS X-RAY.

2. MONITOR CONTACTS SHOWN IN NON-ACTIVATED STATE. 


\section{(6) SOLENOID DOOR LOCK}

ES-1.9-19

GENERAL A SOLENOID DOQR LOCK IS AN ELECTRO-MECHANICAL, PLUNGER-TYPE DEVICE WHICH, WHEN DE-ENERGIZED, MECHANICALLY LOCKS THE
ASSOCIATED SHIELD OR DOOR IN THE CLOSED POSITION.

THE DEVICE SHALL BE USED TO PREVENT ACCESS THROUGH DOORS AND/OR SHIELDS TO AN AREA WHEN HARMFUL RADIATION EXISTS: IN THE. AREA. FOR EXAMPLE, (1) USE OF SOLENOID-DOOR LOCKS INTERLOCKED TO PREVENT ENTRANCE TO A RADIOACTIVE SOURCE VAULT WHIL THE SOURCE IS EXPOSED; (2) SOLENOID-DOOR LOCKS USED IN CONJUNCTION WITH A RADIATION. MONITOR TO PREVENT ACCESS TO AN AREA WHEN RADIATION EXISTS BECAUSE OF EQUIPMENT MALFUNCTION; (3) IN SPECIAL CASES (REFERENCE ES-1.9-20) THE SOLENOID-DOOR LOCK MAY BE TIMED TO PREVENT ACCESS TO A RADIATION AREA FOR A SPECIFIED TIME AFTER THE SYSTEM IS DE-ENERGIZED. IF AN ACCESS DOOR CAN BE OPENED ONLY BY AN ELECTRICAL OR HYDRAUL IC MECHANISM, AN ELECTRICAL INTERLOCK, CONNECTED TO PREVENT OPERATI ON OF THE DOOR OPENER (AS IN FIGURE 4), SATISFIES REQUIREMENTS OF THIS STANDARD.

\section{DESCRIPTION}

SOLENOID-DOOR LOCKS THAT COMPLY WITH THIS STANDARD ARE DESCRIBED IN THE FOLLOWING EXAMPLES. REFERENCE TO MATERIAL OR EQUIPMENT BY BRAND NAME OR MANUFACTURER IS INTENDED TO BE DESCRIPTIVE, NOT RESTRICTIVE, AND IS SOLELY.FOR THE PURPOSE OF INDICATING TYPE OR QUALITY OF ITEM THAT IS ACCEPTABLE.

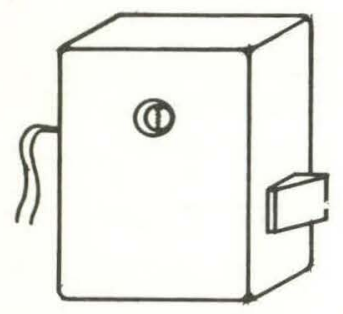

FIG. 1

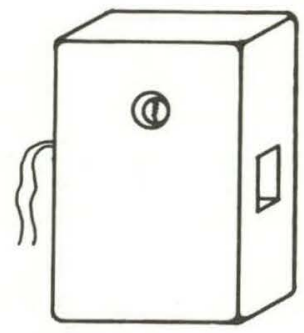

FIG. 2
ELECTRO-MECHANICAL LOCK FOR SLIDING DOOR. FOLGER ADAM COMPANY NO. 55 SERIES

ELECTRO-MECHANICAL LOCK FOR SWING ING DOOR. FOLGER ADAM COMPANY NO. 51 SERIES.

\section{ELEMENTARY DIAGRAMS OF TYPIS.AL CIRCUITS}
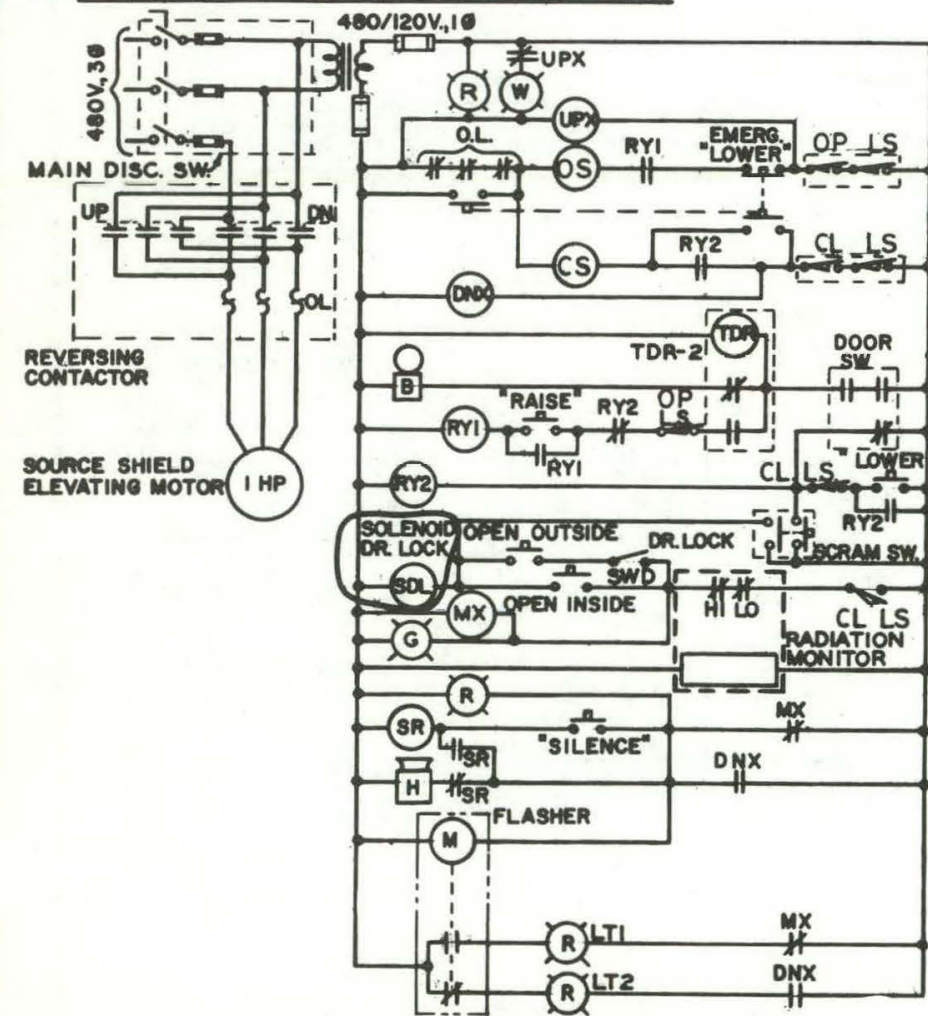

FIG. 3

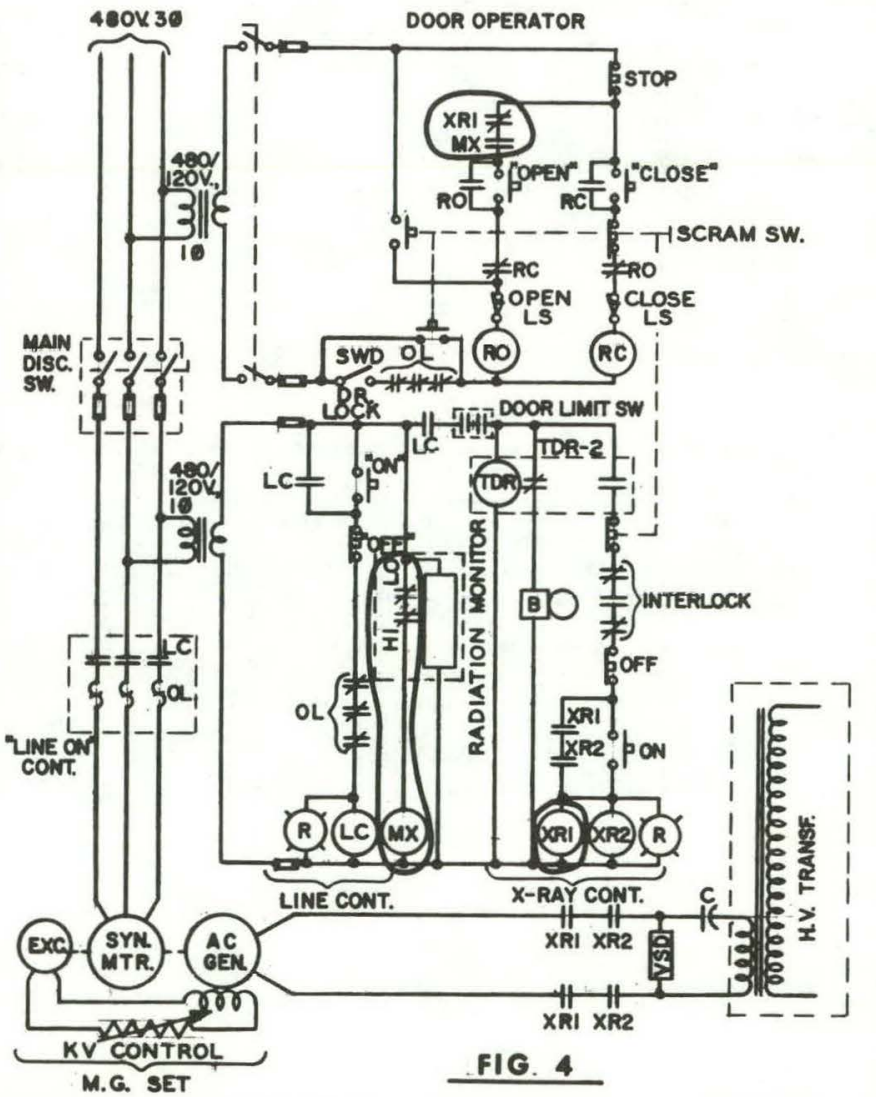




\section{(7) Voltage time decay control}

ES-1.9-20

\section{GENERAL}

VOLTAGE TIME DECAY CONTROL IS A PROVISION TO PREVENT RADIATION EXPOSURE RESULTING FROM RESIDUAL VOLTAGE IN CONSTANT POTENTIAL POWER SUPPLIES.

IF THE EQUIPMENT DESIGN IS SUCH THAT SIGNIFICANT (AS DETERMINED BY RADIATIION SAFETY) LEVELS OF RADIATION CAN EXIST AFTER THE EQUIPMENT IS TURNED OFF AND THE RADIATION AREA IS ACCESSIBLE TO PERSONNEL ADDITIONAL SAFETY PROVISIONS WILL BE REQUIRED. EXAMPLES OF SUCH PROVISIONS ARE A POWER SUPPLY CAPACITOR PERMANENT BLEEDER REŚSISTOR A POWER SUPPLY CAPACITOR SOLENOID OPERATED BLEEDER CIRCUIT, AND A CONTROLLED TIME DELAY ON A RADIATION AREA ACCESS DOOR OPENER.

ELEMENTARY DIAGRAMS OF TYPICAL CIRCUITS

CIRCUITS THAT COMPLY WITH REQUIREMENTS FOR THIS STANDARD ARE SHOWN IN THE FOLLOWING FIGURES:
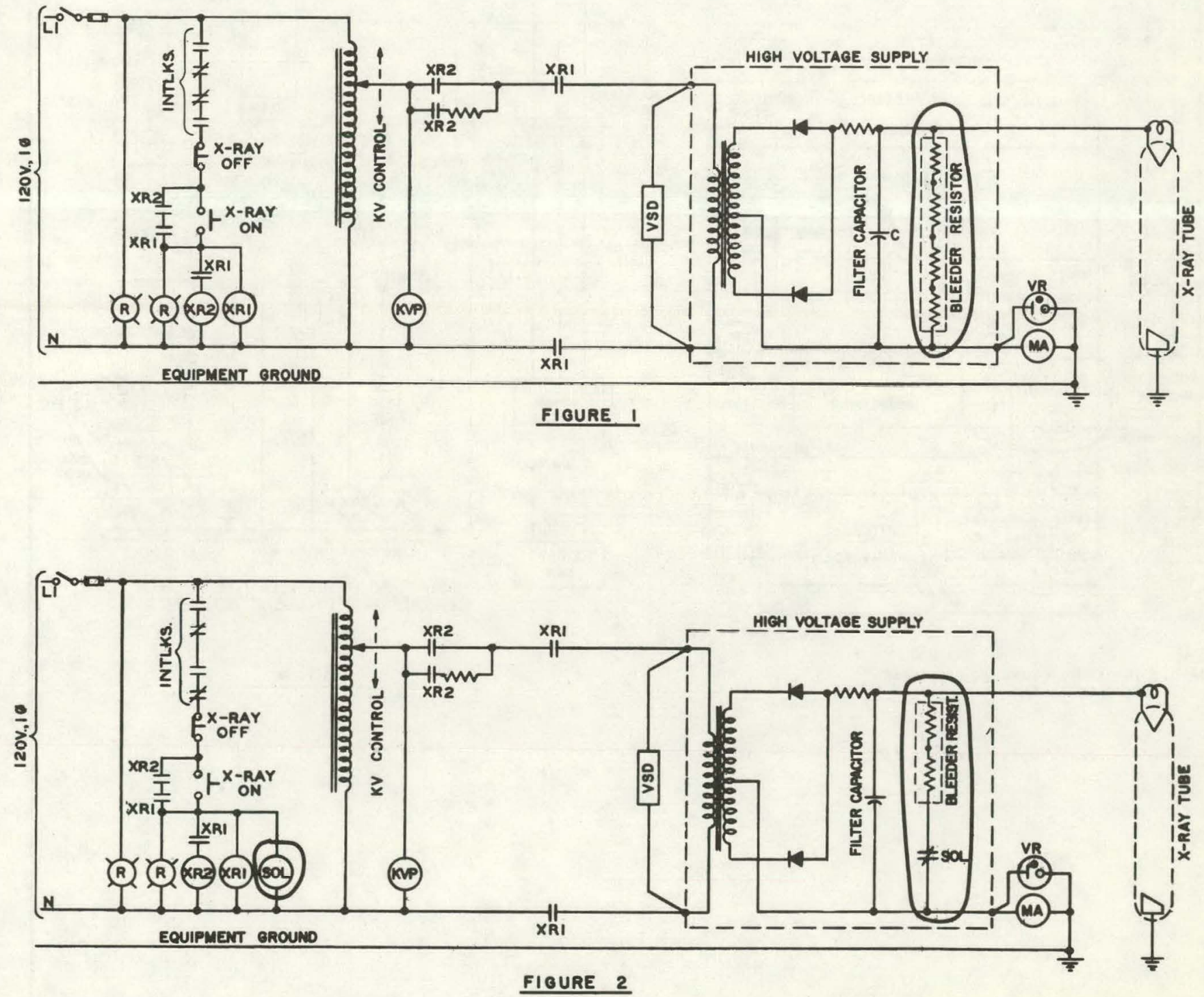
ELEMENTARY DIAGRAMS OF TYPICAL CIRCUITS (CONTINUED)
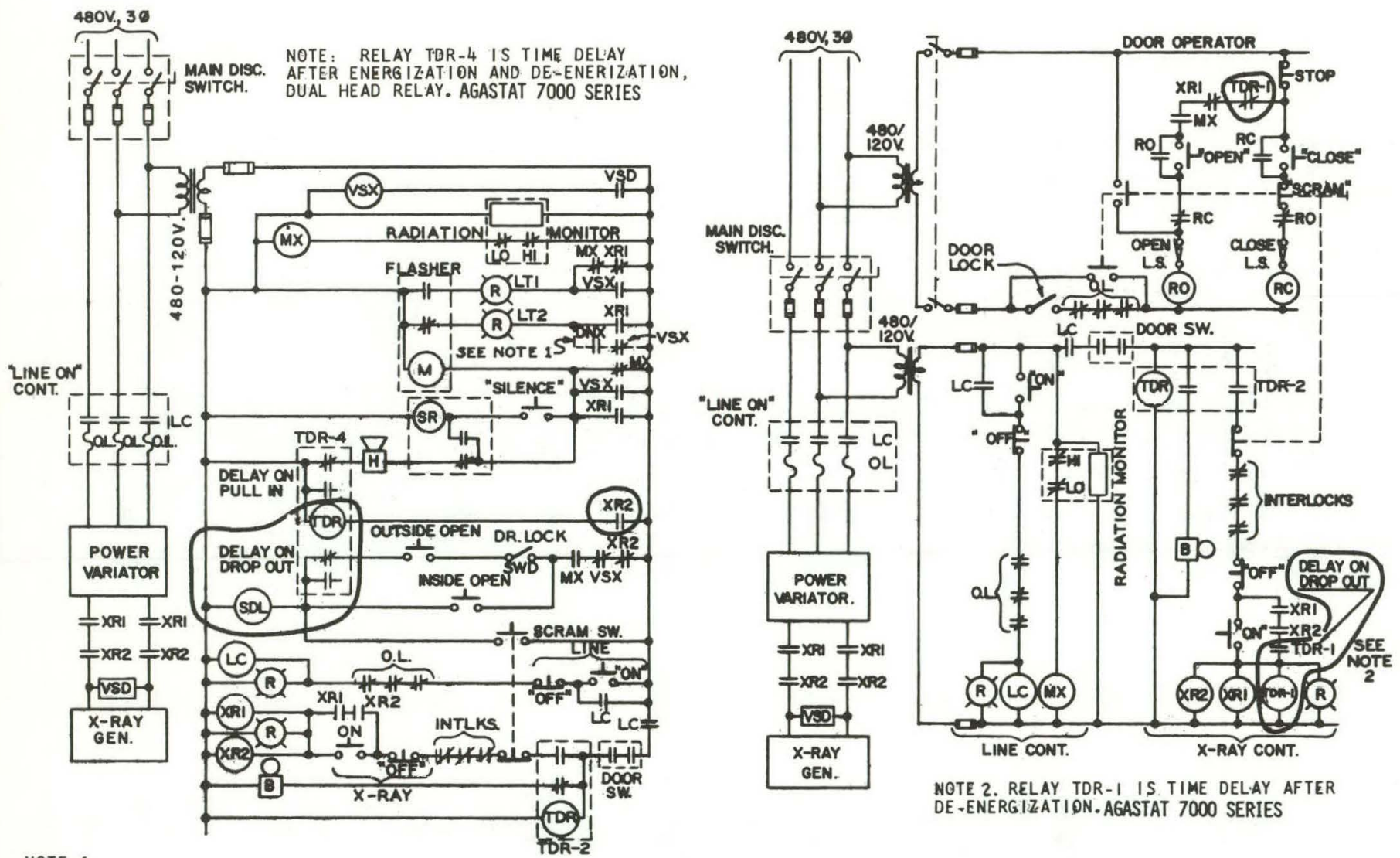

NOTE 1

FIG. 4

ADO CFRCUIT IN DASHED LINES WHEN NUCLEAR

SOURCE IS INSTALLEQ IN SAME FACIL.LTY AS X-RAY.

FIG. 3 


\section{(8) ACCESS DOOR INTERLOCK}

ES-1.9-22

GENERAL

AN ACCESS DOOR INTERLOCK SWITCH IS A DOOR OPERATED LIMIT SWITCH CONNECTED IN THE SYSTEM CONTROL CIRCUIT SUCH THAT THE RADIATION SOURCE CANNOT BE ENERGIZED OR EXPOSED WHILE THE DOOR TO THE RADIATION AREA IS OPEN.

THE ACCESS DOOR INTERLOCK SWITCH WILL BE USED ON ANY PERSONNEL ACCESS DOOR(S) IN VAULTS, CABINETS, OR OTHER ENCLOSURES

WHERE THE PURPOSE OF THE DOOR IS TO PROVIDE NORMAL ACCESS TO THE RADIATION AREA WHILE THE X-RAY GENERATOR IS DE-ENERG IZED

OR THE RADIATION SOURCE IS COMPLETELY SHIELDED. THIS INTERLOCK IS REQUIRED ON ALL ELECTRICALLY-OPERATED SYSTEMS

\section{DESCRIPTION}

AN ACCESS DOOR INTERLOCK SWITCH THAT COMPLIES WITH THE REOUIREMENITS OF THIS STANDARD IS SHOWN IN THE FOLLOWING EXAMPLE. REFERENCE TO MATERIAL OR EQUIPMENT BY BRAND NAME, CATALOG NUMBER. OR NAME OF MANUFACTURER IS INTENDED TO BE DESCRIPTIVE, NOT RESTRICTIVE, AND IS SOLELY FOR INDICATING THE QUALITY OF ITEM THAT IS ACCEPTABLE.

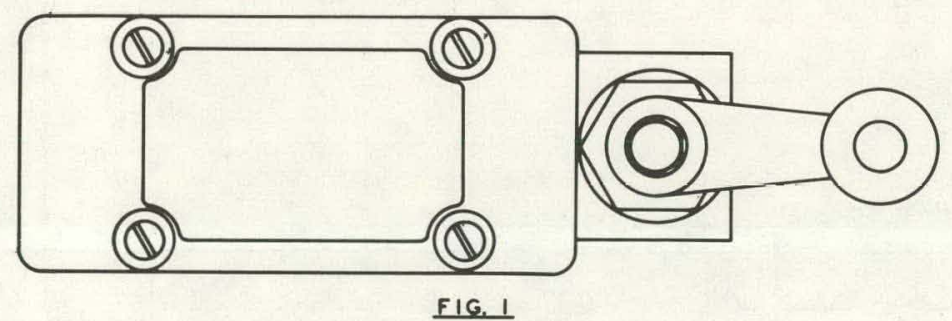

LIMIT SWITCH, HEAVY DUTY OILTIGHT, ROLLER LEVER, DOUBLE

POLE, DOUBLE THROW, 10 AMPS. MICRO-SWITCH TYPE ML.

ELEMENTARY DIAGRAMS OF TYPICAL CIRCUITS
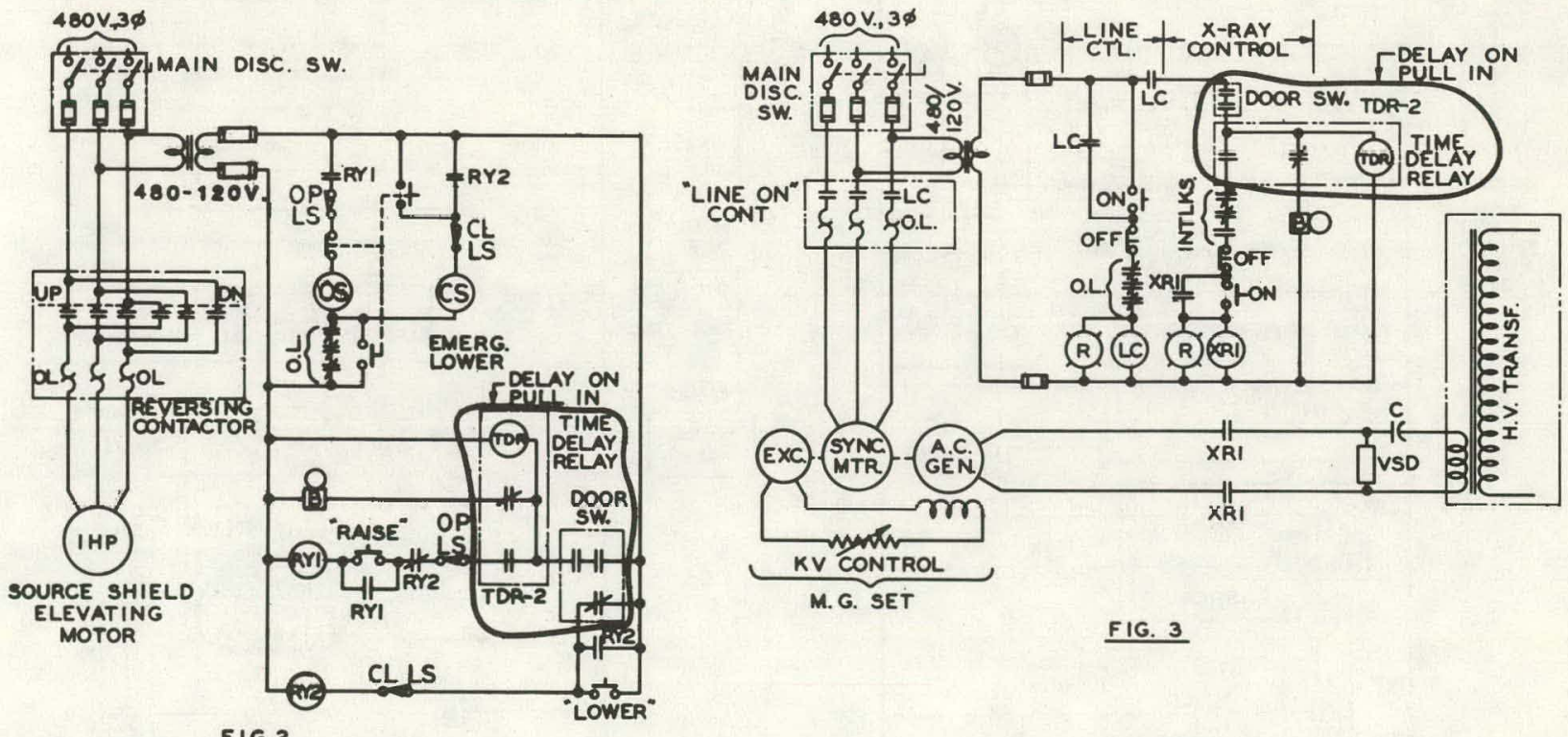

FIG. 3

POSITION OF DOOR SWITCHES IN FIGURE 2 WILL BE AS

SHOWN EXCEPT WHEN VAULT DOOR IS COMPLETELY CLOSED. 
GENERAL

AN ENCLOSURE PANEL INTERLOCK SWITCH IS AN ENCLOSURE PANEL OPERATED ENCLOSED SWITCH CONNECTED IN THE SYSTEM CONTROL CIRCUIT SUCH THAT THE RADIATION SOURCE CANNOT BE ENERGIZED OR EXPOSED WHILE THE ENCLOSURE PANEL IS REMOVED.

THE ENCLOSURE PANEL INTERLOCK SWITCH WILL BE USED ON ANY ENCLOSURE PANEL WHERE THE PURPOSE OF THE PANEL IS TO LIMIT ACCESS

TO THE RADIATION AREA WHILE THE X-RAY GENERATOR IS ENERG IZED OR THE RAD IATION SOURCE IS EXPOSED. ENCLOSURE PANELS, BY
DEF INITION, WILL BE LIMITED TO THOSE PANELS DE SCRIBED ABOVE THAT ARE REMOVABLE WITHOUT TOOLS.

DESCRIPTION

AN ENCLOSURE PANEL INTERLOCK SWITCH THAT COMPLIES WITH THE REQUIREMENTS OF THIS STANDARD IS SHOWN IN THE FOLLOWING EXAMPLE. REFERENCE TO MATERIAL OR EQUIPMENT BY BRAND NAME, CATALOG NUMBER, OR NAME OF. MANUFACTURER IS INTENDED TO BE DESCRIPTIVE,

NOT RESTRICTIVE, AND IS SOLELY FOR THE PURPOSE OF INDICATING THE QUALITY OF ITEM THAT IS ACCEPTABLE.

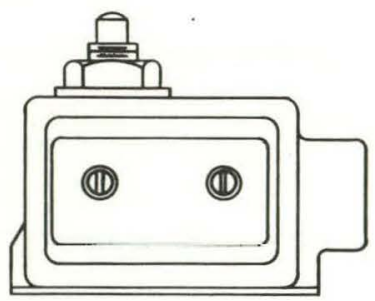

ENCLOSED SWITCH, SINGLE POLE,

DOUBLE THROW, MOMENTARY CONTÁCT,

15 AMP, 120 VOLTS, $60 \mathrm{HZ}$, MICRO

SWITCH,' TYPE E6.
NOTES

1. ADD CKT. IN DASHED LINES WHEN NUCLEAR SOURCE IS USED IN SAME
FACILITY AS X-RAY.

FIG. 1

ELEMENTARY DIAGRAMS OF TYPICAL CIRCUITS

MAIN DISC. SW.

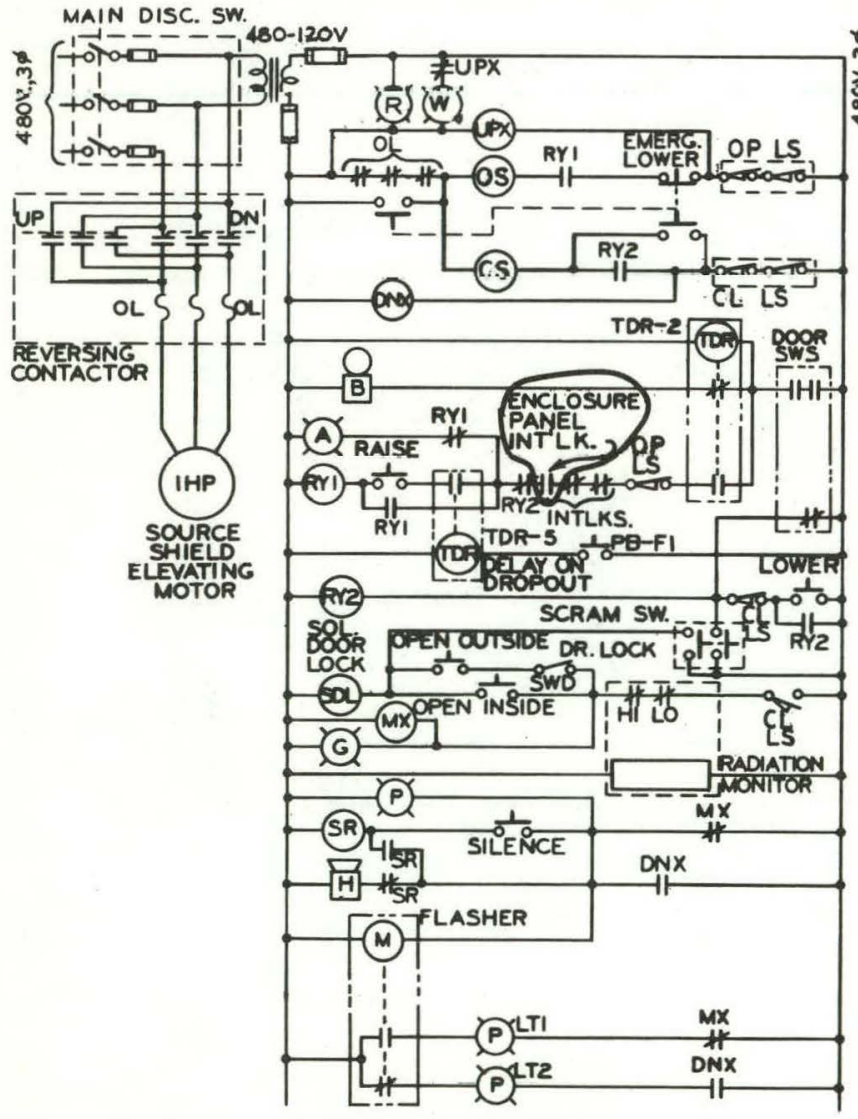

FIG. 2

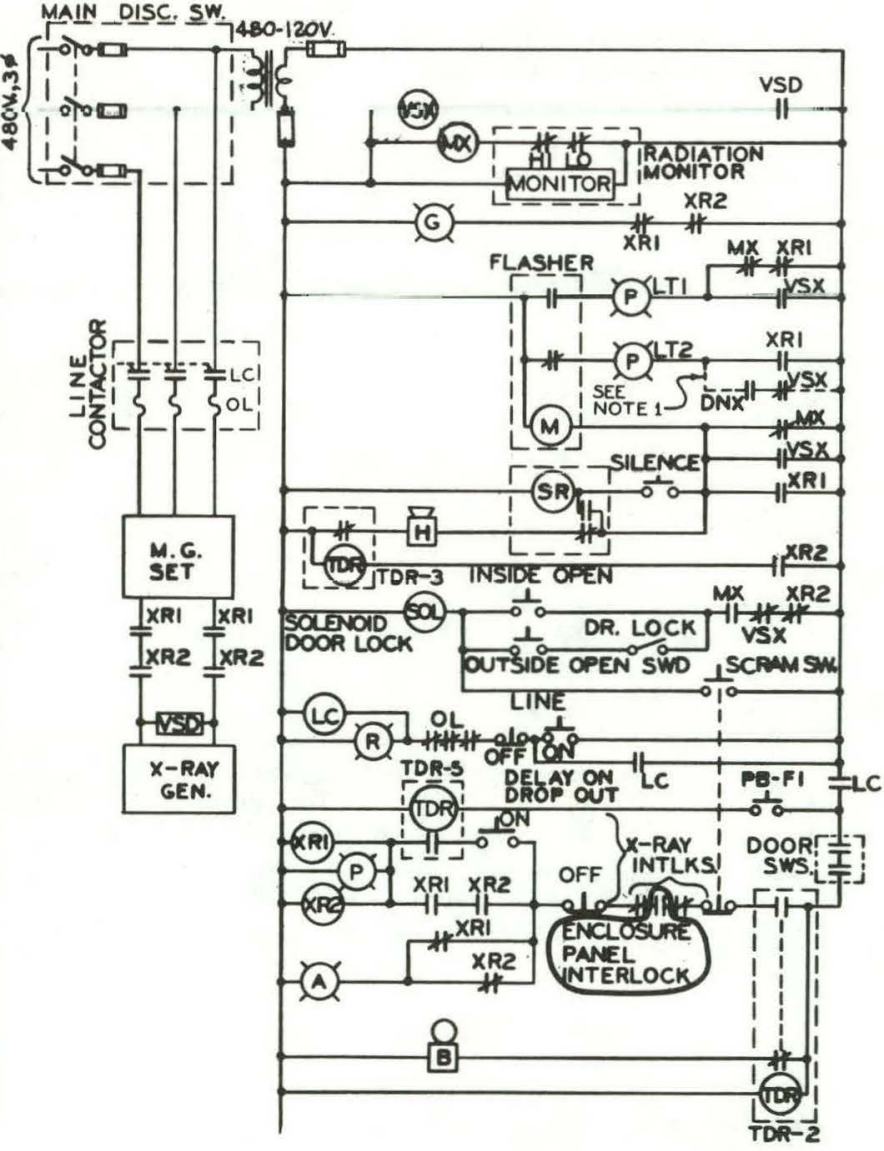

FIG. 3 
GENERAL

A RADIATION SHIELD INTERLOCK SWITCH IS A RADIATION SHIELD OPERATED ENCLOSED SWITCH CONNECTED IN THE SYSTEM CONTROL CIRCUIT SUCH THAT THE RADIATION SOURCE CANNOT BE ENERG IZED OR EXPOSED WHILE THE RADIATION SHIELD IS REMOVED.

THE RADIATION SHIELD INTERLOCK SWITCH WILL BE USED ON ANY SHIELD WHERE THE PURPOSE OF THE SHIELD IS TO PREVENT RADIATION FROM PENETRATING A WORK AREA WHILE THE X-RAY GENERATOR IS ENERGIZED OR THE RADIATION SOURCE IS EXPOSED. RADIATION SHIELDS, BY DEFINITION, WILL BE LIMITED TO THOSE SHIELDS DESCRIBED ABOVE THAT ARE REMOVABLE WITHOUT TOOLS.

\section{DESCRIPTION}

A RADIATION SHIELD INTERLOCK SWITCH THAT COMPLIES WITH THE REQUIREMENTS OF THIS STANDARD IS SHOWN IN THE FOLLOWING EXAMPLE. REFERENCE TO MATERIAL OR EQUIPMENT BY BRAND NAME, CATALOG NUMBER, OR NAME OF MANUFACTURER IS INTENDED TO BE DESCRIPTIVE, NOT RESTRICTIVE, AND IS SOLELY FOR THE PURPOSE OF IND'ICATING THE QUALITY OF ITEM THAT IS ACCEPTABLE.

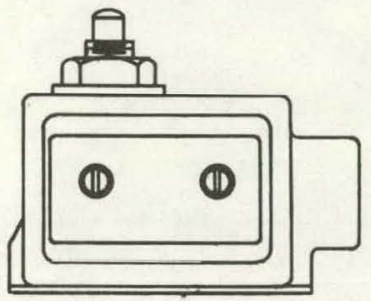

ENCLOSED SWITCH, SINGLE POLE,

DOUBLE THROW, MOMENTARY CONTACT

15 AMP, 120 VOLTS, $60 \mathrm{HZ}$, MICRO

SWITCH, TYPE E6.

FIG. I

\section{ELEMENTARY DIAGRAMS OF TYPICAL CIRCUITS}

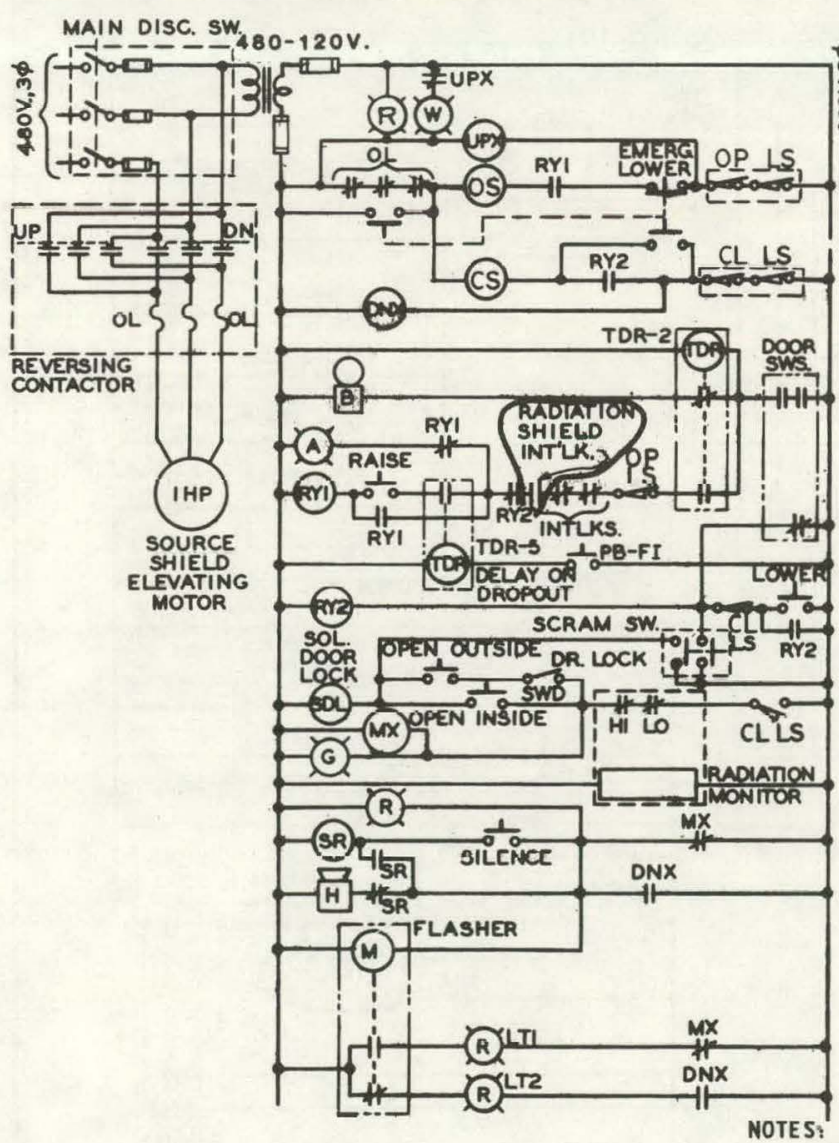

FIG. 2

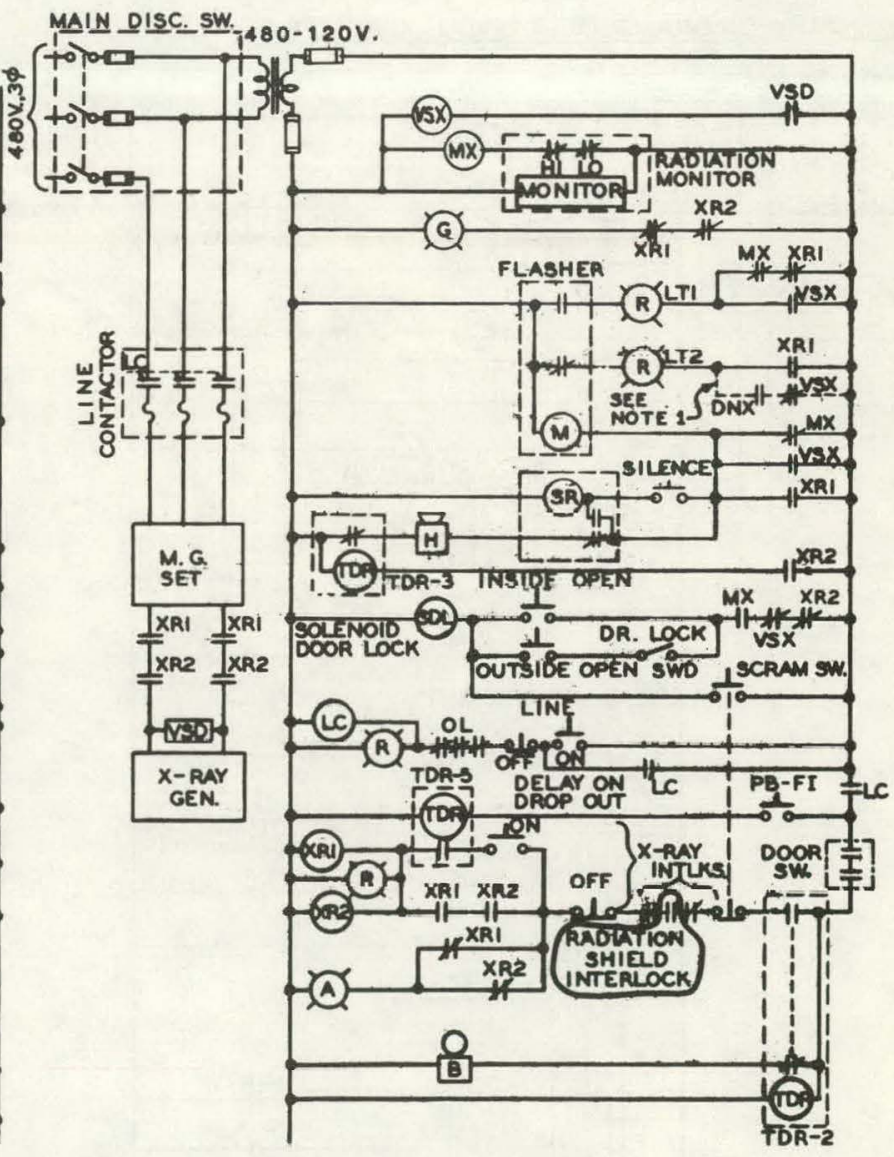

FIG. 3 
GENERAL

A BARRICADE INTERLOCK SWITCH IS A BARRICADE OPERATED ENCLOSED SWITCH CONNECTED IN THE SYSTEM CONTROL CIRCUIT SUCH THAT THE RADIATION SOURCE CANNOT BE ENERGIZED OR EXPOSED WHILE THE BARRICADE IS REMOVED.

THE BARRICADE INTERLOCK SWITCH WILL BE USED ON ANY BARRICADE WHERE THE PURPOSE OF THE BARRICADE IS TO LIMIT ACCESS TO THE RADIATION AREA WHILE THE X-RAY GENERATOR IS ENERG IZED OR THE RADIATION SOURCE IS EXPOSED.

DESCRIPTION

A BARRICADE INTERLOCK SWITCH THAT COMPLIES WITH THE REQUIREMENTS OF THIS STANDARD IS SHOWN IN THE FOLLOWING EXAMPLE. REFERENCE TO MATERIAL OR EQUIPMENT BY BRAND NAME, CATALOG NUMBER, OR NAME OF MANUFACTURER IS INTENDED TO BE DESCRIPTIVE, NOT RESTRICTIVE, AND IS SOLELY FOR THE PURPOSE OF INDICATING THE QUAL ITY OF ITEM THAT IS ACCEPTABLE.

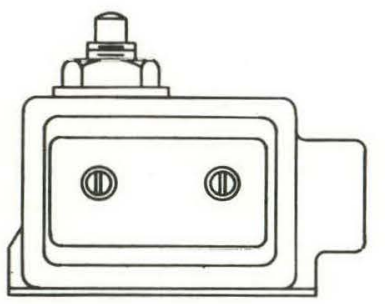

ENCLOSED SWITCH, SINGLE POLE,

DOUBLE THROW, MOMENTARY CONTACT,
15 AMP, 120 VOLTS, $60 \mathrm{HZ}$, MICRO

SWITCH, TYPE E6.

NOTES

1. ADD CKT. IN DASHED LINES WHEN NUCLEAR SOURCE IS USED IN SAME FACILITY AS X RAY.

FIG. 1

ELEMENTARY DIAGRAMS OF TYPICAL CIRCUITS

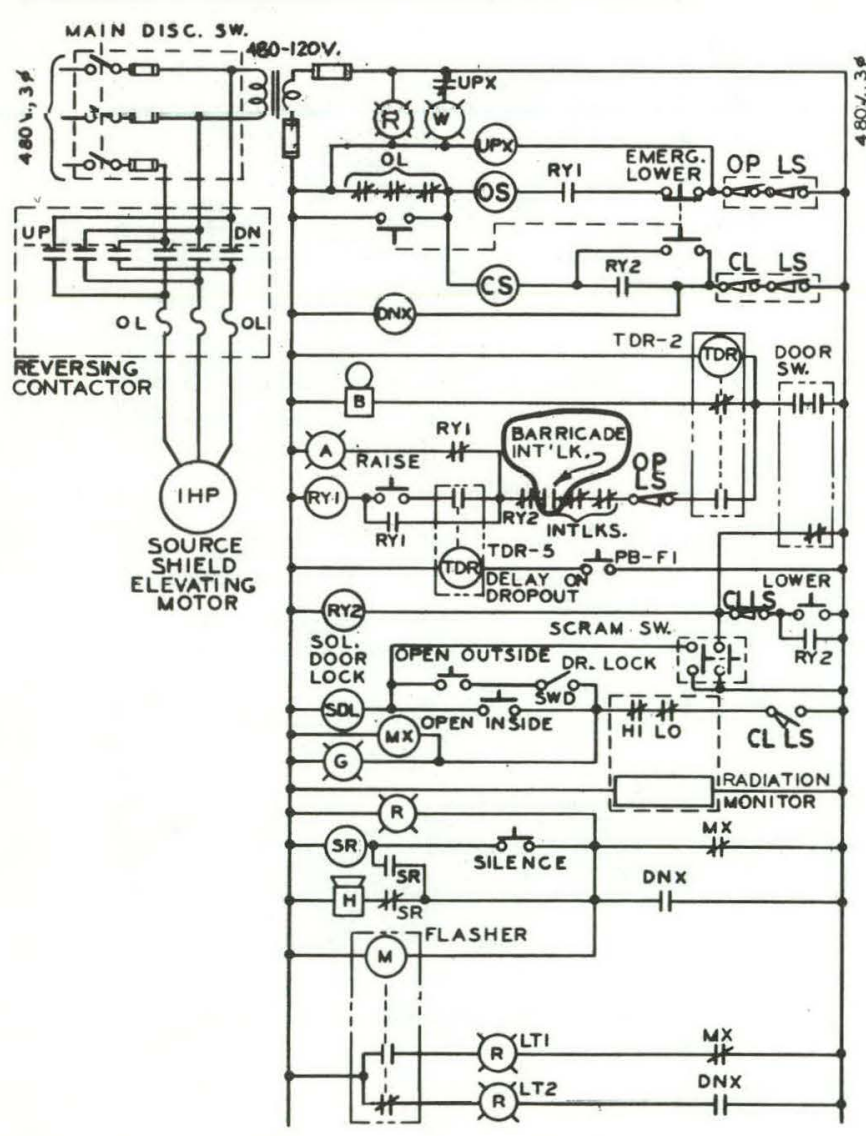

FIC. 2

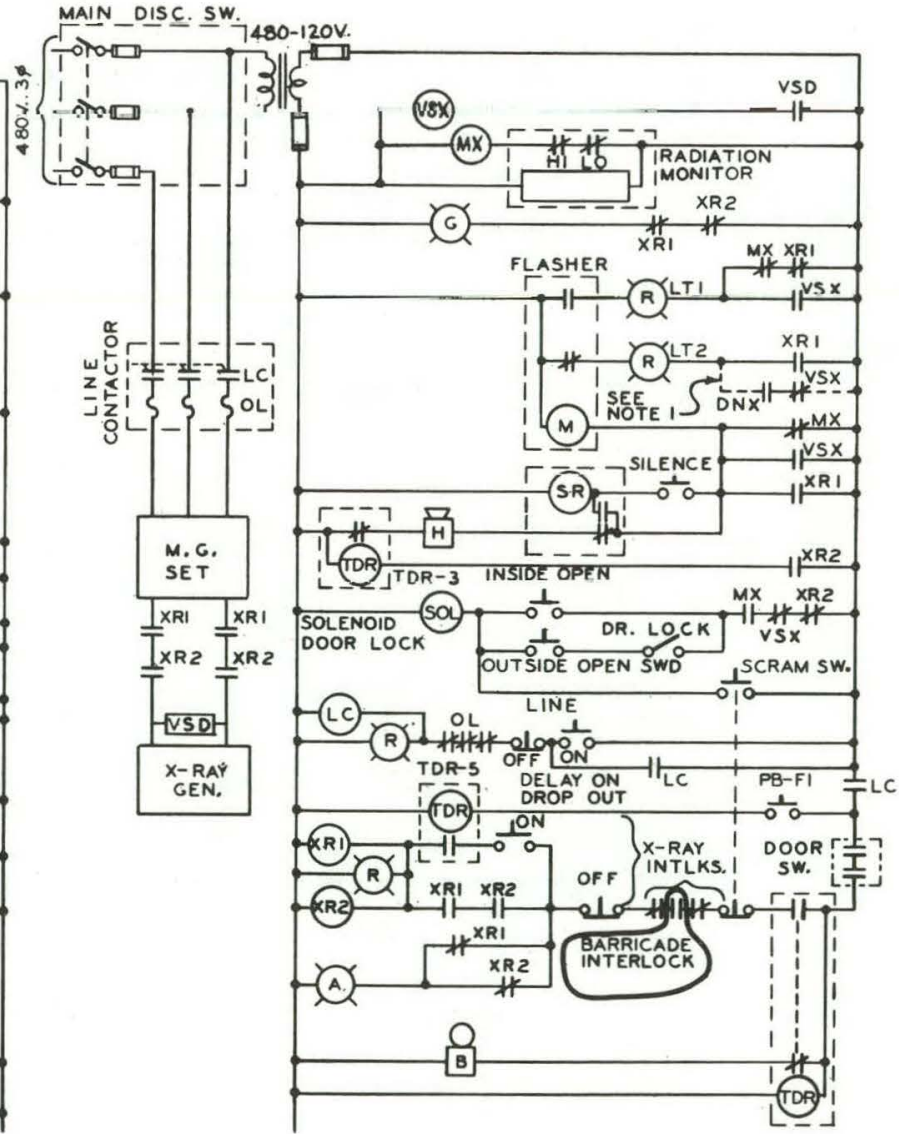

FIG. 3 
GENERAL

A SCRAM SWITCH IS A MANUALLY OPERATED PUSHBUTTON SWITCH CONNECTED IN THE SYSTEM-CONTROL CIRCUIT TO (1) DE-ENERGIZE OR SHIELD A RADIATION SOURCE UNDER EMERGENCY CONDITIONS UNTIL THE SWITCH HAS BEEN RESET AFTER IT HAS BEEN ACTUATED, AND

THE MANUALLY -OPERATED SWITCH IS REQUIRED IN VAULTS AND BARRICADED AREAS TO PROVIDE EMERGENCY SHUTDOWN OF THE SYSTEM BY PERSONNEL IN THE AREA. THE SCRAM SWITCH(ES) WILL BE LOCATED IN A CONVENIENTLY ACCESSIBLE PLACE IN THE WORK AREA AND WILL BE BE RESET TO THE "ON" POSITION AT ITS IMMEDIATE LOCATION.

\section{DESCRIPTION}

AN EMERGENCY SCRAM PUSHBUTTON SWITCH THAT COMPLIES WITH THE REQUIREMENTS OF THIS STANDARD IS SHOWN IN THE FOLLOWING EXAMPLE.

REFERENCE TO MATERIAL OR EQUIPMENT BY BRAND NAME, CATALOG NUMBER, OR NAME OF MANUFACTURER IS INTENDED TO BE DESCRIPTIVE,
NOT RESTRICTIVE, AND IS SOLELY FOR INOICATING THE QUALITY OF ITEM THAT IS ACCFPTABIE.

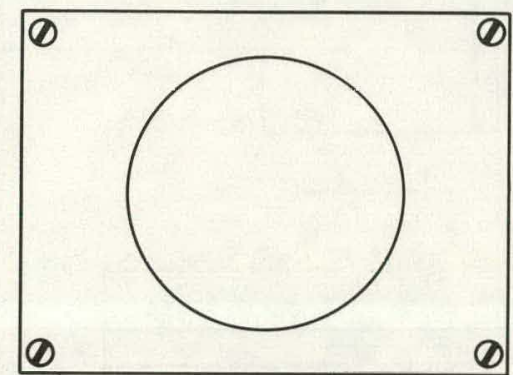

FIG. 1

ELEMENTARY DIAGRAMS OF TYPICAL CIRCUITS

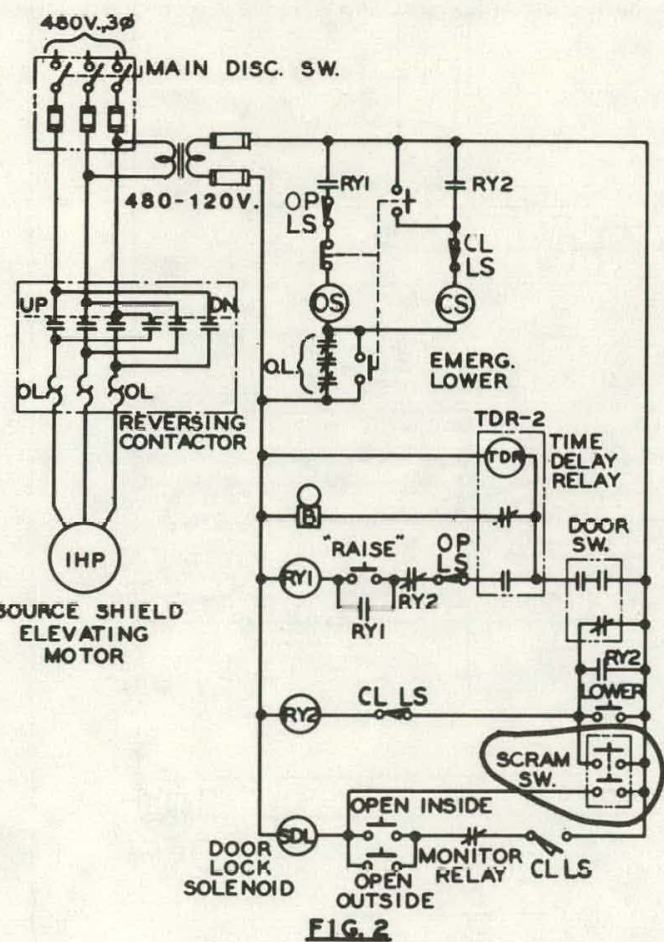

PUSHBUTTON UNIT, HEAVY DUTY OILTIGHT, WITH MOMENTARY CONTACT BLOCK, DOUBLE POLE

DOUBLE THROW 2 N. 0 AND 2 N.C 10 AMP

RATED CONTACTS AND A MAINTAIN TÝPE SINGL

$21 / 4$ INCH RED MUSHROOM HEAD BUTTON

OPERATOR WHICH WILL "PUSH TO STOP" AND

"PULL TO RESET" FURNAS ELECTRIC CO, CLASS 50

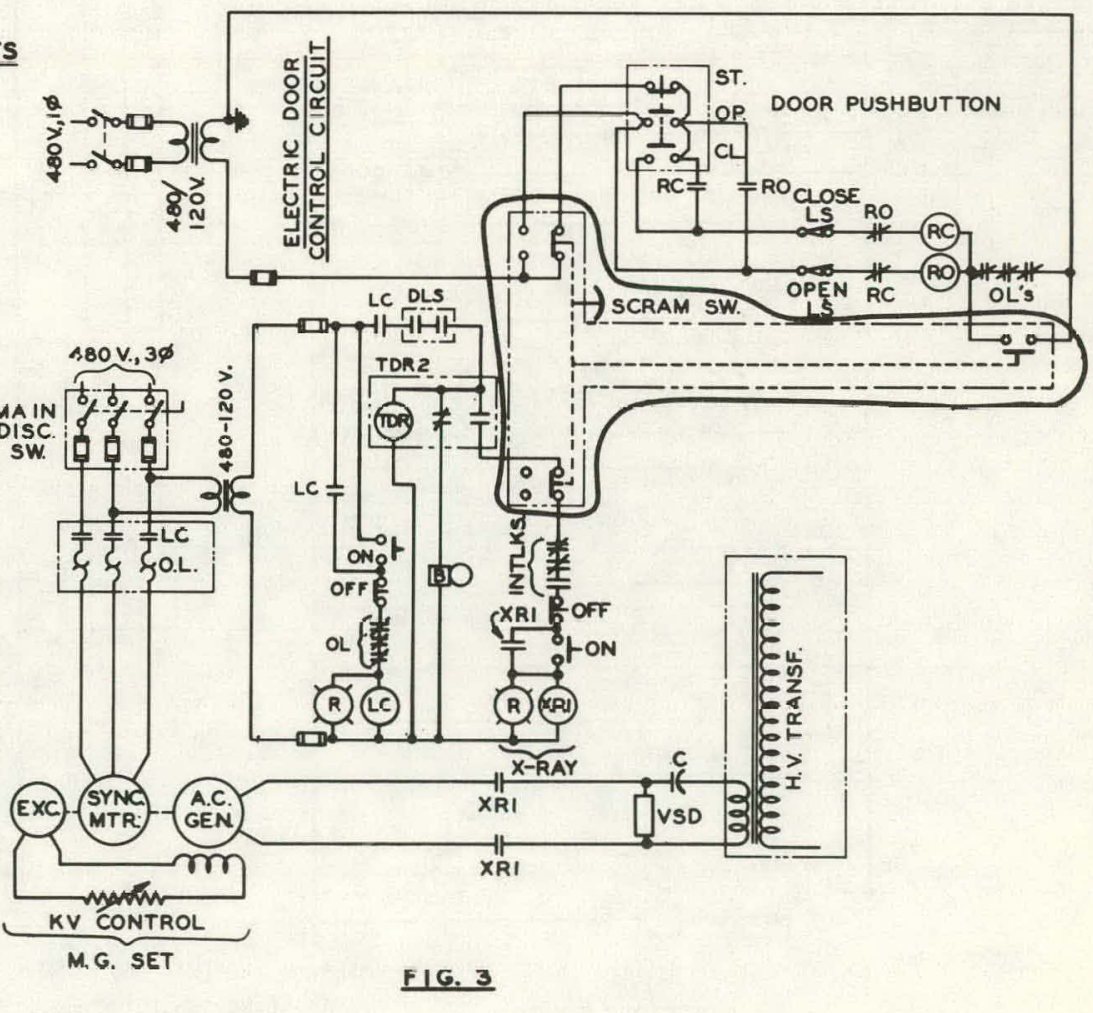


GENERAL

A"FORCED INSPECTION"INTERLOCK IS A MANUALLY OPERATED PUSHBUTTON OR KEY SWITCH CONNECTED IN THE SYSTEM CONTROL CIRCUIT SUCH THAT THE RADIATION SOURCE MAY BE ENERGIZED ONLY DURING A PRESET TIME INTERVAL.

THE MANUALLY OPERATED SWITCH WILL BE INSTALLED IN VAULTS AND BARRICADED AREAS IN A WAY THAT WILL FORCE SURVEILLANCE OF THE AREA FOR PERSONNEL WHO MAY HAVE ENTERED UNNOTICED.

\section{DESCRIPTION}

A"FORCED INSPECTION"SWITCH THAT COMPLIES WITH THE REQUIREMENTS OF THIS STANDARD IS SHOWN IN THE FOLLOWING EXAMPLES. REFERENCE TO MATERIAL OR EQUIPMENT BY BRAND NAME, CATALOG NUMBER, OR NAME OF MANUFACTURER IS INTENDED TO BE DESCRIPTIVE。 NOT RESTRICTIVE, AND IS SOLELY FOR THE PURPOSE OF INDICATING THE QUAL ITY OF ITEM THAT IS ACCEPTABLE.

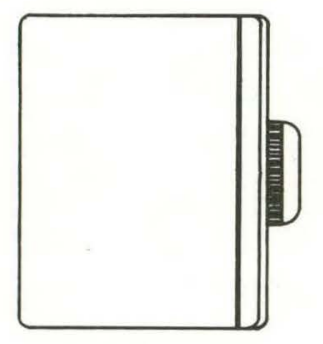

FIG. 1
PUSHBUTTON UNIT, HEAVY DUTY OILTIGHT, WITH MOMENTARY CONTACT BLOCK, SINGLE POLE,

DOUBLE THROW, 1 N. 0 . AND 1 N.C. , 6 AMP

RATED CONTACTS, WITH EI THER A FĹUSH-HEAD

OPERATOR AND BLACK BUTTON OR A CYL INDER

KEY -LOCK OPERATOR. ALLEN-BRADLEY, BULLETIN $800 T$ T.

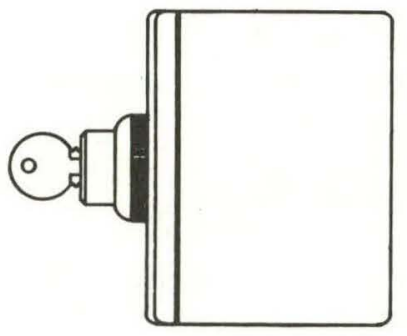

FIG. 2

\section{ELEMENTARY DIAGRAMS OF TYPICAL CIRCUITS}

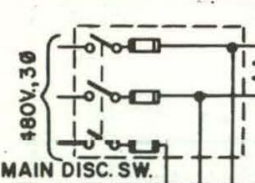

MAIN DISC.SW.

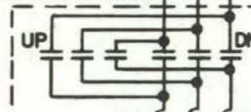

O.L.S SOL!

REVERSING

CONTACTOR

SOURCE SHIELO ELEYATING

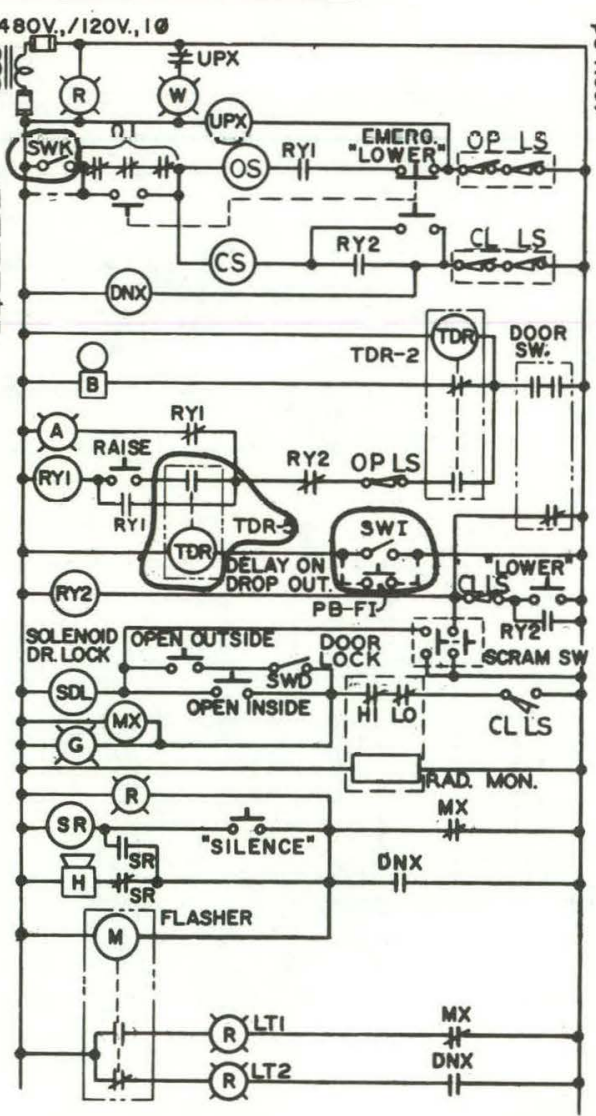

FIG. 3
NOTES:

1. ADD CIRCUIT IN DASHED LINES WHEN NUCLEAR SOURCE IS INSTALLED IN SAME FACILITY AS $X$-RAY.

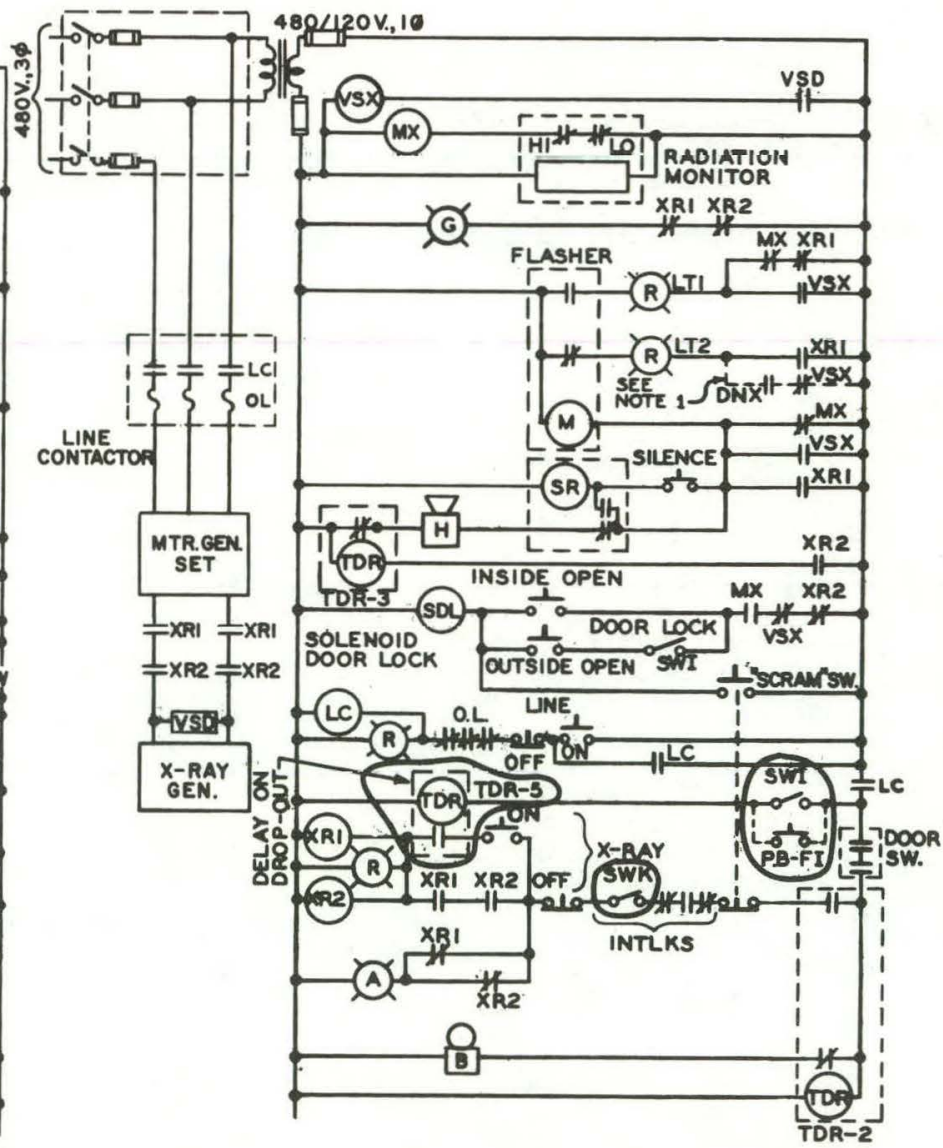

FIG. 4 
GENERAL

A RADIATION BEAM POSITION INTERLOCK SWITCH(ES) IS A RADIATION BEAM POSITION OPERATED ENCLOSED SWITCH(ES) CONNECTED IN THE SYSTEM CONTROL CIRCUIT SUCH THAT THE RADIATION SOURCE WILL BE DE-ENERGIZED IF IT IS NOT AIMED WITHIN THE PRESCRIBED DIRECTIONS

SHIELDING IS SOMETIMES DESIGNED FOR CERTAIN OPERATING DIRECTIONS AND IS NOT ADEQUATE FOR OTHERS. IN SUCH CASES THE EQUIPMENT IS INTERLOCKED TO PREVENT SUCH OPERATION. FOR EXAMPLE. THE SHIELD OVER AN X-RAY MACHINE MAY NOT BE DESIGNED TO ADEQUATELY SHIELD THE DIRECT BEAM ON THE PREMISE THAT IT WOULD NEVER BE NECESSARY TO AIM THE DIRECT BEAM TOWARD THE CEILING. IN SUCH A CASE THE MACHINE WOULD BE INTERLOCKED TO PREVENT AIMING IT IN THAT DIRECTION.

\section{DESCRIPTION}

A RADIATION BEAM POSITION INTERLOCK SWITCH(ES) THAT COMPLIES WITH THE REOUIREMENTS OF THIS STANDARD IS SHOWN IN THE FOLLOWING EXAMPLE. REFERENCE TO MATERIAL OR EQUIPMENT BY BRAND NAME CATALOG NUMBER OR NAME OF MANUFACTURER IS INTENDED TO BE

DESCRIPTIVE, NOT RESTRICTIVE, AND IS SOLELY FOR THE PURPOSE OF INDICATING THE QUALITY OF ITEM THAT IS ACCEPTABLE.

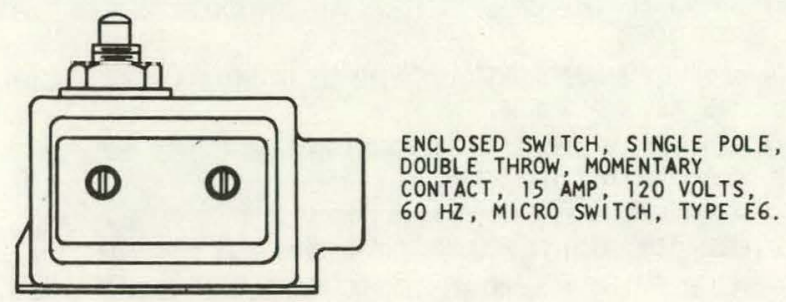

FIG. 1

\section{ELEMENTARY DIAGRAMS OF TYPICAL CIRCUITS}
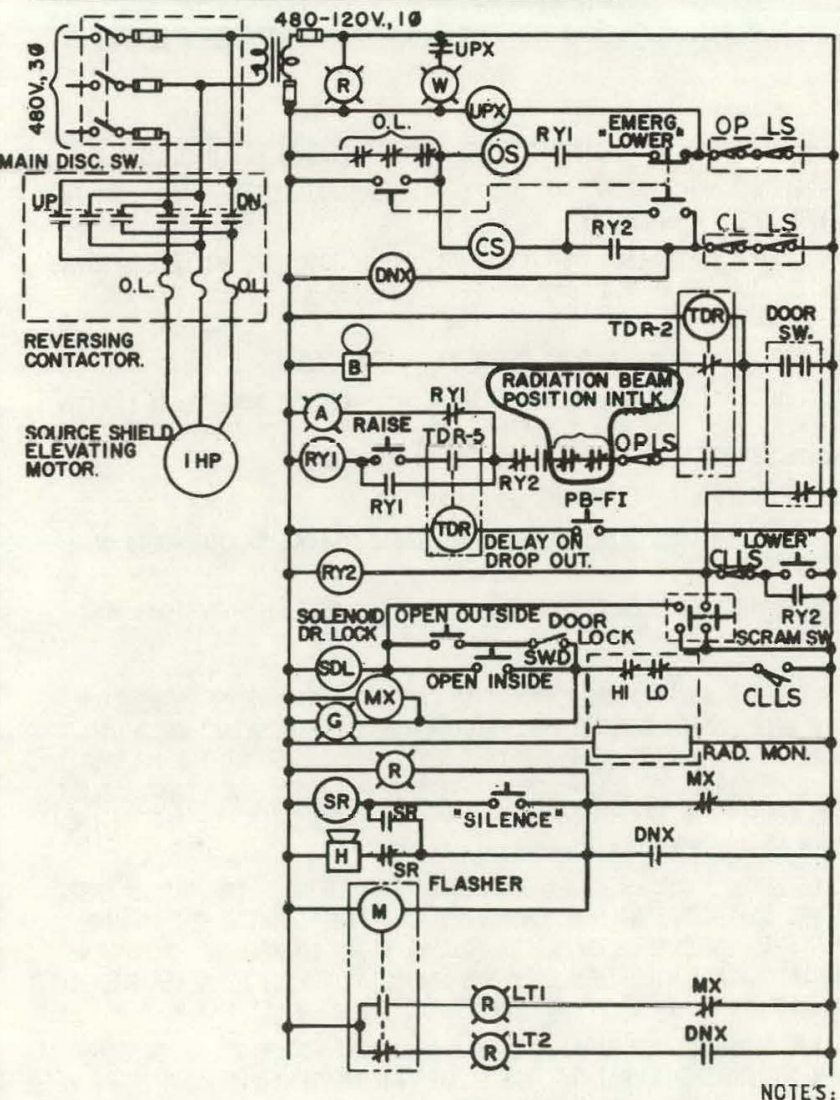

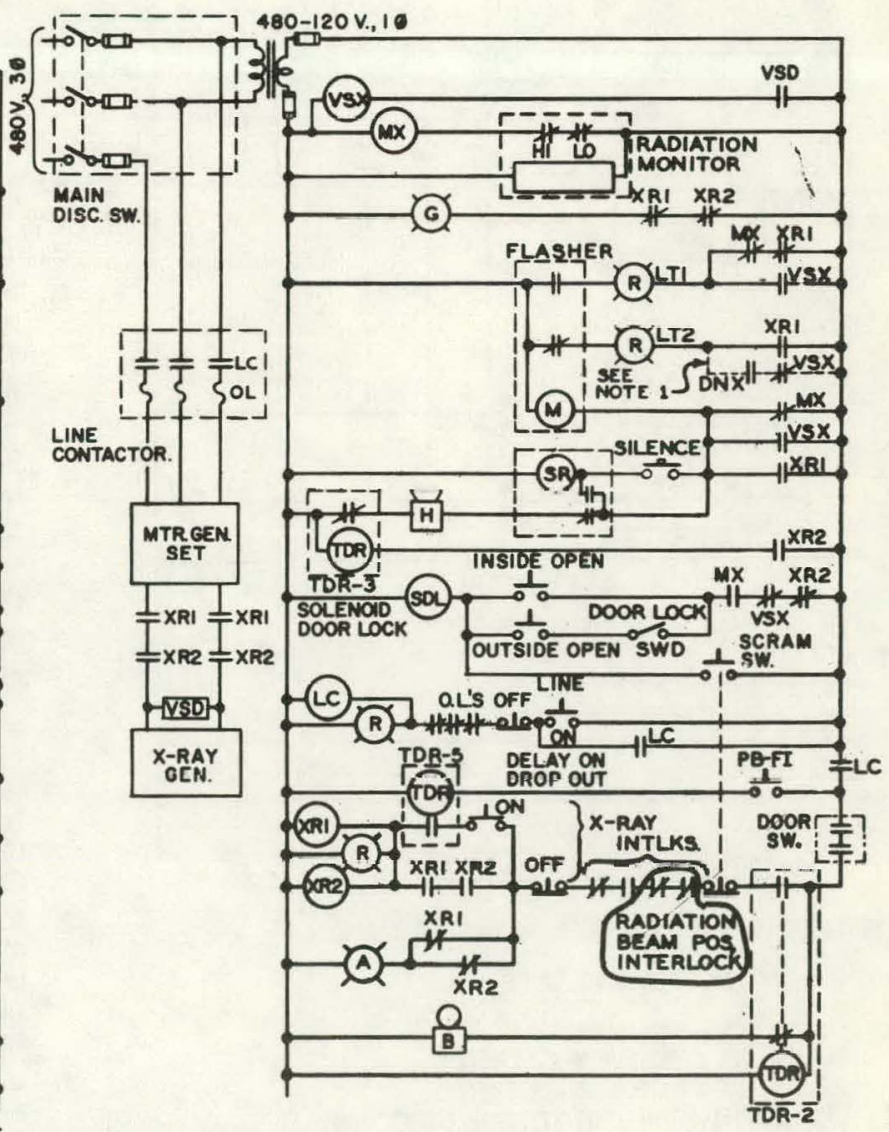

FIG. 3

1. ADD CIRCUIT, IN DASHED LINES

FIG. 2

WHEN NUCLEAR SOURCE IS

INSTALLED IN SAME FACILITY AS X-RAY 
GENERAL

A LIGHT FAILURE INTERLOCK IS AN ELECTRICAL AND/OR ELECTRONIC DEVICE TO DETECT THE FAILURE OF ONE OR MORE OF THE WARNING LIGHTS AND DE-ENERGIZE THE RADIATION SOURCE.

THE LIGHT FAILURE INTERLOCK DEVICE SHALL BE CONNECTED IN THE SYSTEM CONTROL CIRCUIT SUCH THAT IF ONE OR MORE OF THE FLASHING WARNING LIGHTS FAIL THE DEVICE WILL DE-ENERGIZE THE X-RAY RADIATION SOURCE OR SHIELD THE RADIOACTIVE SOURCE, THIS DEVICE WOULD BE USED WHERE THERE IS A HIGH-LEVEL HAZARD OR WHERE THE SAFETY OF PERSONNEL IS HEAVILY DEPENDING UPON SAFETY LIGHTS. DESCRIPUION

A LIGHT FAILURE INTERLOCK DEVICE THAT COMPLIES WITH THE REQUIREMENTS OF THIS STANDARD IS SHOWN IN THE FOLLOWING EXAMPLE. REFERENCE TO MATERIAL OR EQUIPMENT BY BRAND NAME, CATALOG NUMBER, OR NAME OF MANUFACTURER. IS INTENDED TO BE DESCRIPTIVE, NOT RESTRICTIVE, AND IS SOLELY FOR THE PURPOSE OF INDICATING THE, QUALITY OF ITEM THAT IS ACCEPTABLE. (ㄴ)

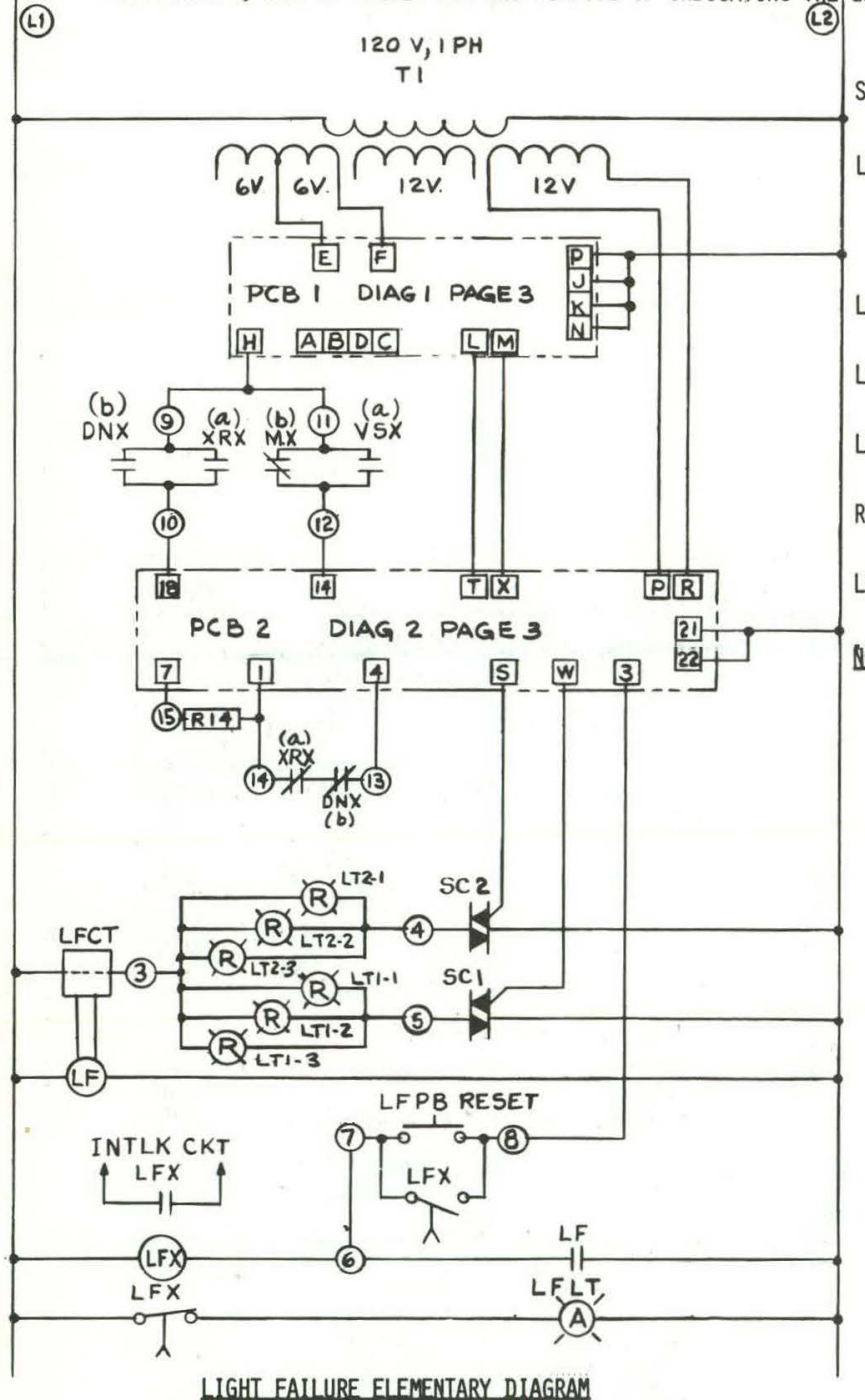

(FOR INSTALLATION WITH MORE THAN TWO SETS OF 120 VOLT, 100 WATT FLASHING LAMPS, )

(a) USE XRX \& VSX FOR X-RAY SYSTEMS,

(b) USE DNX \& MX FOR SOURCE SYSTEMS.

(3) TERMINAL POINTS FOR EXTERNAL CONNECTIONS.
SCI-SC2 - TRIAC, BI-DIRECTIONAL, SILICON, GATE CONTROLLED, GENERAL ELECTRIC TYPE SC45B,

- 125 VOLT INCANDESCENT LAMPS WITH RED OR MAGENTA GLOBE \& GUARD, SEE ES-1,9-37 \& 38,

- Light failuRe PROTECTIVE SENSOR tranSFoRMER, J-10 AMPS, $60 \mathrm{HZ}$, GUARDIAN TYPE IR-CT1-202.

- Light faIlURE PROTECTIVE SENSOR RELAY, 120 VOLTS, 0,10-, 40 SEC, TIME DELAY ON RELEASE, GUARDIAN P/N2121-0996-2206.

- Light failure aUX, RELAY, 120 VOLt COIL, ALLEN-BRADLEY TYPE N, WITH TIMER STACK, TIME RANGE 0.1 TO 5 SEC,

- Light FAILURE, PILOT LT, TRANSF, TYPE, 120 VOLTS, 60 HZ, WITH AMBER LENS, SQUARE D CLASS 9001 ,

- TIMING RESISTOR, COMP, CARBON, FIXED, 1/2W, NOMINAL RESISTANCE 10,000 OHMS $(50,000$ OHMS/SEC.),

- light failure pushiutton, ONE N,0, CONTACT, tO RESET lFX RELAY,

NOTES:

1. ALL RELAY CONTACTS ARE SHOWN WITH RELAY IN DE-ENERGIZED CONDITION.

2. WITH X-RAY OFF AND RADIOACTIVE SOURCE SHIELDED AND CONTROL POWER ON THE FOLLOWING CONDITIONS EXIST

A. THE SYSTEM ENERGIZING CONTACTOR AUX, RELAY XRX, THE VOLTAGE SENSING DEVICE AUX, RELAY VSX, AND THE SHIELD CLOSED AUX, RELAY DNX ARE DE-ENERGIZED.

B. THE RADIATION MONITOR AUX, RELAY MX IS ENERGIZED,

C. THE LIGHT FAILURE RELAY LF AND THE LIGHT FAILURE AUX, RELAY LFX ARE DE-ENERGIZED, THE LFX RELAY HAS ONE OR MORE INSTANTANEOUS CONTACTS AND TWO TIME DELAY CONTACTS (DELAY ON PICK-UP),

D. THE LIGHT FAILURE LAMP LFLT IS ENERGIZED.

E. THE LIGHT FAILURE TIME DELAY RELAY TDRLF (DELAY ON DROP-OUT) IS ENERGIZED,

TO ENERGIZE THE X-RAY OR EXPOSE THE SOURCE THE FOLLOWING ACTIONS MUST BE TAKEN:

1. RESET THE LIGHT FAILURE CIRCUIT BY ACTUATING THE RESET PUSHBUTTON, THIS WILL ENERGIZE RELAY LFX THROUGH THE CLOSED CONTACT OF RELAY TDR/LF, A LFX TIME DELAY CONTACT WILL SEAL IN AROUND THE PUSHBUTTON, THE OTHER LFX TIME DELAY CONTACT WILL DE-ENERGIZE THE LIGHT FAILURE LAMP LFLT, THE LFX INSTANTANEOUS CONTACTS CLOSE IN ONE AND/OR THE OTHER UNITS INTERLOCK CIRCUIT,

2. ACTUATE THE X-RAY ON OR EXPOSE SOURCE PUSHBUTTON, THE SYSTEM ENERGIZING CONTACTORS HILL BE ENERGIZED, IF THE FLASHING RED WARNING LIGHTS ARE GOOD THEN THE LIGHT FAILURE RELAY LF WILL BE ENERGIZED, THE LF CONTACT WILL THEN KEEP THE LFX RELAY ENERGIZED AFTER THE TIMED CONTACT OF RELAY TDR/LF HAS OPENED. THE UNIT WILL REMAIN ENERGIZED.

3. IF THE FLASHING RED WARNING LIGHTS ARE NOT GOOD OR OME OR MORE SHOULD BURN OUT DURING OPERATION, THE LIGHT FAILURE RELAY LF WILL DE-ENERGIZE AND DROP OUT THE LIGHT FAILURE AUX. RELAY LFX WHICH WILL DE-ENERGIZE THE X-RAY UNIT OR SHIELD THE RADIOACTIVE SOURCE AND ENERGIZE THE LIGHI FAILURE LAMP LFLT. 
DESCRIPUION

A LIGHT FAILURE INTERLOCK DEVICE FOR USE WITH ANALYTICAL X-RAY EQUIPMENT THAT COMPLIES WITH THE REQUIREMENTS OF THIS STANDARD

IS SHOWN IN THE FOLLOWING EXAMPLE. REFERENCE TO MATERIAL OR EQUIPMENT BY BRAND NAME, CATALOG NUMBER, OR NAME OF MANUFACTURER

IS INTENDED TO BE DESCRIPTIVE, NOT RESTRICTIVE, AND IS SOLELY FOR THE PURPOSE OF INDICATING THE QUALITY OF ITEM THAT IS

ACCEPTABLE,

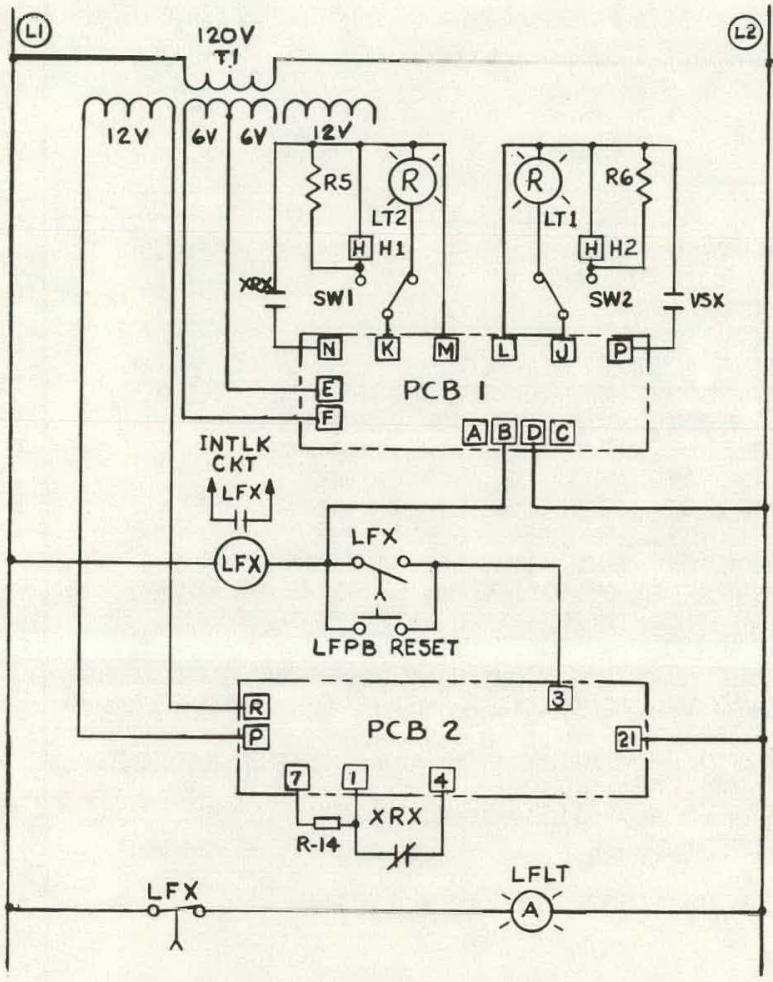

COMPONENT IDENTIEICALION

T1 - TRANSFORMER, 120 VOLT PRIMARY, THREE 12 VOLT SEC, WINDINGS, CHICAGO STANDARD TRANSF, TYPE P-8364.

PCB I - LIGHT FLASHER PRINTED CIRCUIT BOARD AS SHOWN IN DIAGRAM 1 , PAGE 3.

PCB 2 - LIGHT FAILURE PRINTED CIRCUIT BOARD AS SHOWN IN DIAGRAM 2, PAGE 3.

LT1 \& LT2 - PILOT LIGHT ASSEMBLY FOR USE WITH A T-3-1/4 MBB LAMP \#47, RED LENS.

LFLT - LIGHT FAILURE PILOT LIGHT ASSEMBLY FOR USE WITH A T-3-1/4 MBB LAMP \#47, AMBER LENS.

LFX - LIGHT FAILURE AUX, RELAY, 120 VOLT COIL, ALLEN-BRADLEY TYPE N, WITH TIMER STACK.TIME RANGE 0.1 TO 5 SEC.

R5 \& R6 - RESISTOR, COMP, CARBON, FIXED, 1 WATT, 27 OHMS,

H1 \& H2 - SONALERT ELECTRONIC AUDIBLE SIGNAL, 2800 HZ, 6-28 VOLTS D,C, MALLORY SC628.

SW1 \& SW2 -SWITCH TOGGLE, SPDT, 125 VOLT, 6 A,

R14 - TIMING RESISTOR, COMP, CARBON, FIXED, 1/2 W, NOMINAL RESISTANCE 10,000 OHMS $(50,000$ OHMS/SEC, $)$

LFPB - LIGHT FAILURE PUSHBUtTON, ONE N.0, CONTACT, TO RESET LFX RELAY,

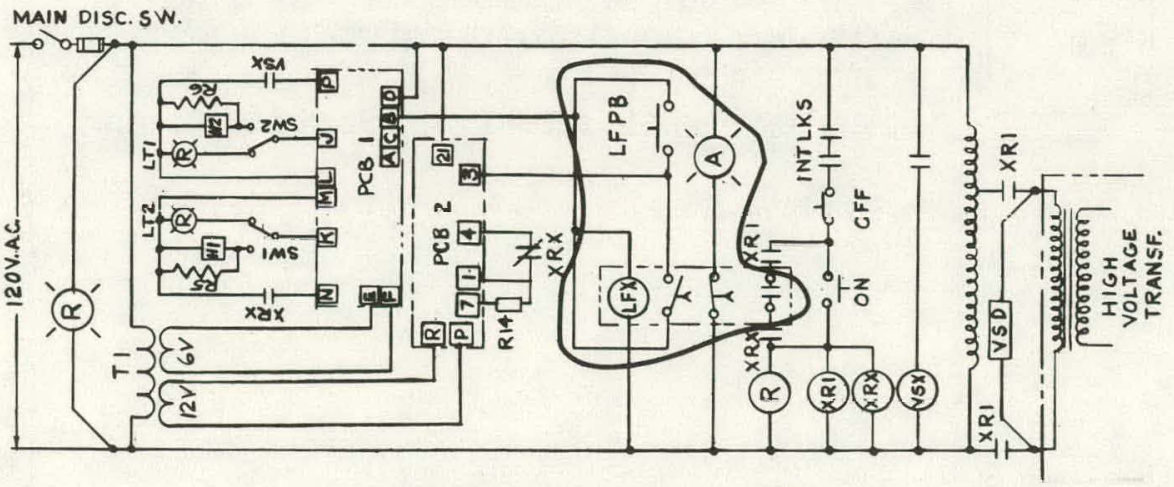




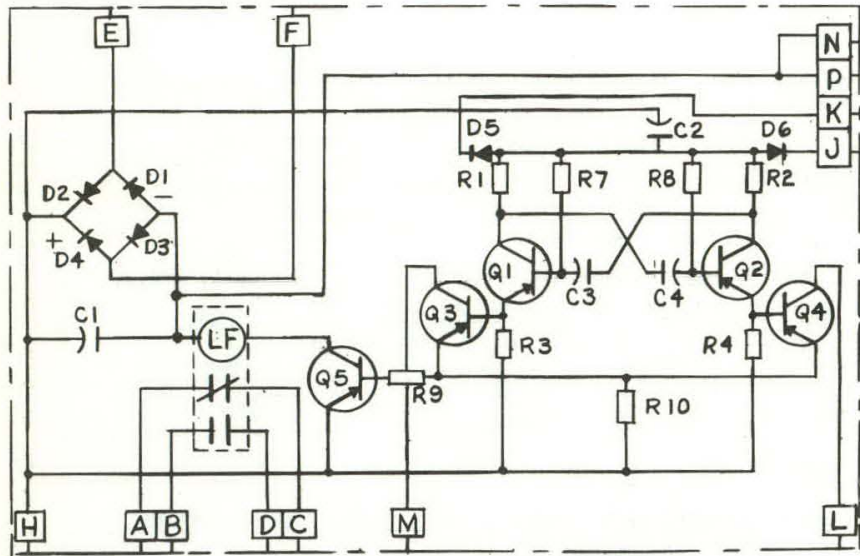

PRINTED CIRCUIT BOARD I DLAGRAM 1

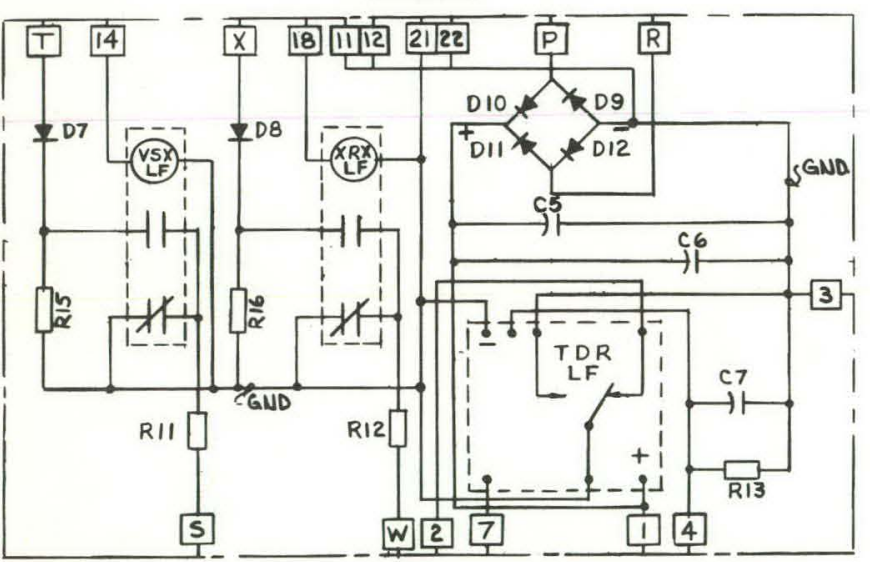

PRINTED CIRCUIT BOARD 2 DLAGRAM 2

\section{COMPONENT IDENTIEICATION}

LF - PROTECTIVE SENSOR RELAY, 120 VOLTS, GUARDIAN TYPE IR-CSI-220,

D1-D8 - DIODE, SILICON, IN4006.

Q1-Q2 - TRANSISTOR, 2N2084.

Q3-05. - TRANSISTOR, 2N526.

C1-C2 - CAPACITOR, FIXED, DRY ELECTROLYTIC, 1000 MFD, 15 VDC, MALLORY,

C3-C4 - CAPACITOR, FIXED, DRY ELECTROLYTIC, 50 MFD, 50 VDC, MALLORY,

R1-R4 - RESISTOR, COMP, CARBON, FIXED, 1/2W, 2400 OHMS,

R7-R8 - RESISTOR, COMP, CARBON, FIXED, 1/2W, 27,000 OHMS,

R9 - RESISTOR, COMP, CARBON, FIXED, 1/2W, 180 OHMS,

RIO - RESISTOR, COMP, CARBON, FIXED, 1/2W, 7.5 OHMS,

R11-R12 - RESISTOR, COMP, CARBON, FIXED, 1/2W, 240 OHMS,

R13 - RESISTOR, COMP, CARBON, FIXED, 1/2W, 10,000 OHMS,

C5-C6 - CAPACITOR, FIXED, DRY ELECTROLYTIC, 150 MFD, 50 VDC, MALLORY,

C7 - CAPACITY, FIXED, DRY ELECTROLYTIC, 1 MFD, 25 VDC, MALLORY,

D9-D12 - BRIDGE RECTIFIER, MALLORY TYPE MAL-7250,

TDR/LF - TIME DELAY RELAY LIGHT FAILURE, DELAY ON DROP-OUT, 12 VOLT COIL, TIME RANGE 200 MSEC-100 SEC, , 50,000 OHMS/SEC, , MAGNECRAFT WS03-PCSRX-2.

VSX/LF - VOLTAGE SENSING AUX, RELAY, LIGHT FAILURE, DRY REED, 6 VDC COIL, MAGNECRAFT W103PCX-1.

XRX/LF - X-RAY ON AUX, RELAY, LIGHT FAILURE, DRY REED, 6 VDC COIL, MAGNECRAFT W103PCX-1.

R15-R16 RESISTOR, COMP, CARBON, FIXED, 1/2 W, 1000 OHMS,

\section{REFERENCE DHG.}

C-E-36000- STANDARD FLASHING LIGHTS P.C. BOARD \#1.

C-E-36001- STANDARD FLASHING LIGHTS P.C. BOARD \#1.

C-E-35999 - STANDARD FLASHING LIGHTS P.C. BOARD \#1.

D-E-53219 - X-RAY FACILITIES STANDARD LIGHT FAILURE P.C.B. \#2 LAYOUT

D-E-53220 - X-RAY FACILITIES STANDARD LIGHT FAILURE P.C.B. \#2 LAYOUT

D-E-53221 - X-RAY FACILITIES STANDARD LIGHT FAILURE P.C.B. \#2 SCHEMATIC DIAG.

E-E-88358 - X-RAY FACILITIES STANDARD LIGHT FAILURE BOARD LAYOUT \& WIRING DIAGRAM, 


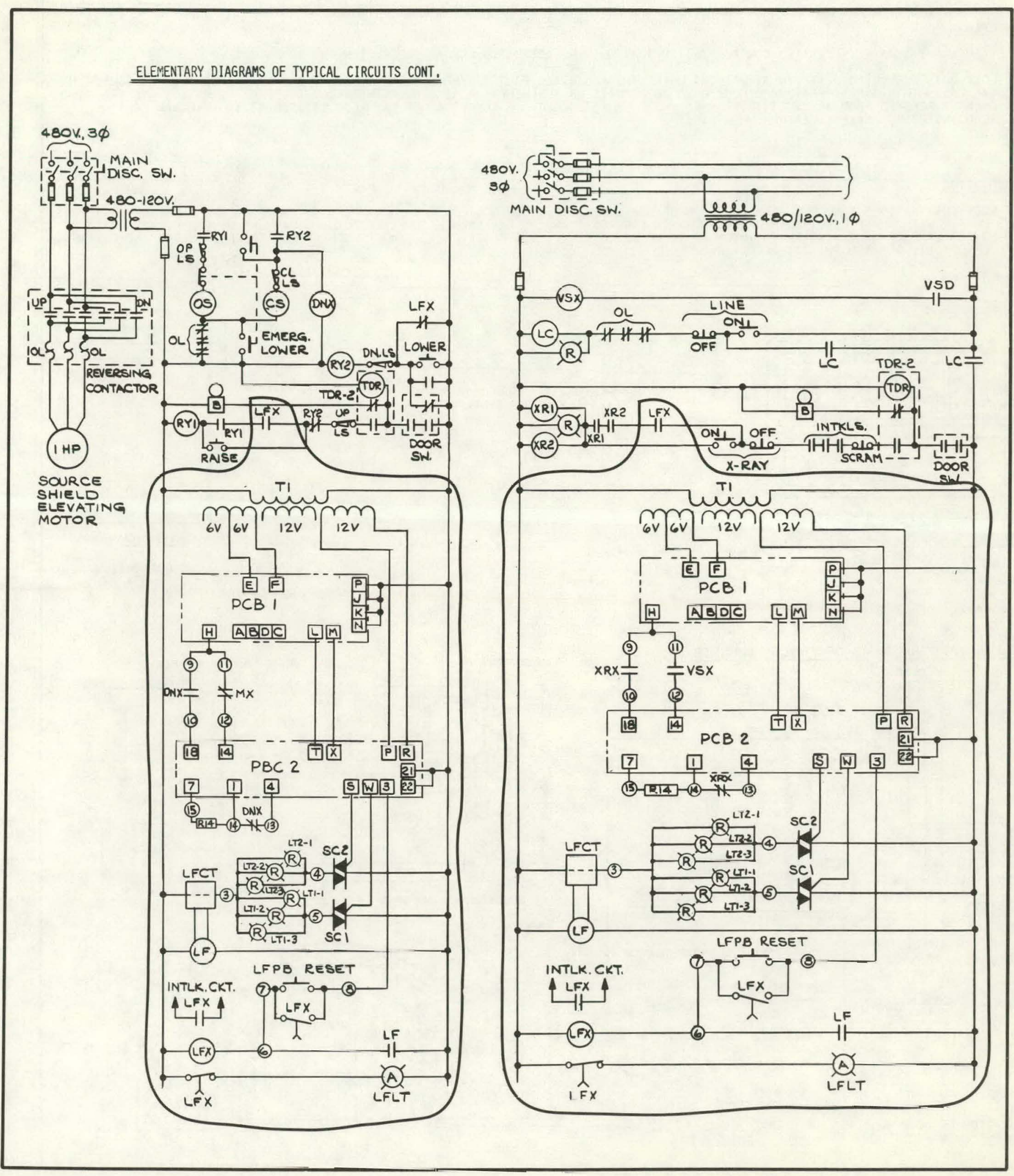


GENERAL

A KEY LOCK-OUT IS A KEY OPERATED CONTROL SWITCH THAT MUST BE ACTIVATED BEFORE THE SYSTEM CAN BE ENERGIZED.

KEY LOCK-OUTS ARE APPROPRIATE IN SITUATIONS WHERE THE RADIATION PART OF THE SYSTEM IS ISOLATED FROM THE CONTROL CONSOLE. IN SPECIAL CASES THIS SAFETY FEATURE CAN BE USED TO REPLACE OR SUPPLEMENT ACCESS DOOR INTERLOCK SWITCHES BY HAVING ONE REY WHICH CAN ONLY BE REMOVED FROM AN ACCESS DOOR WHEN THE DOOR IS LOCKED. A KEY LOCK-OUT MAY ALSO BE USED AS AN INTEGRAL PART OF A FORCED INSPECTION SAFETY FEATURE.

\section{DESCRIPTION}

KEY LOCK-OUT SWITCHES SHOULD BE INSTALLED ON OR NEAR THE SYSTEM CONTROL CONSOLE. EXAMPLES OF SWITCHES AND MOUNTING LOCATIONS THAT COMPLY WITH THESE REQUIREMENTS ARE SHOWN IN FIGURES 1 AND 2. REFERENCE TO MATERIAL OR EQUIPMENT BY BRAND NAME, CATALOG NUMBER, OR NAME OF MANUFACTURER IS INTENDED TO BE DESCRIPTIVE, NOT RESTRICTIVE, AND IS SOLELY FOR THE PURPOSE OF INDIICATING

TYPE OR QUALITY OF ITEM THAT IS ACCEPTABLE.

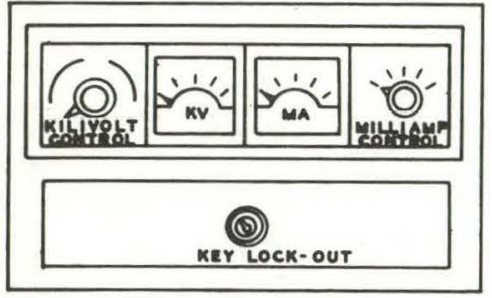

EIG. 1

SHOWING KEY LOCK-OUT SWITCH MOUNTED ON CONTROL CONSOLF.

ELEMENTARY DIAGRAMS OF TYPICAL CIRCUITS

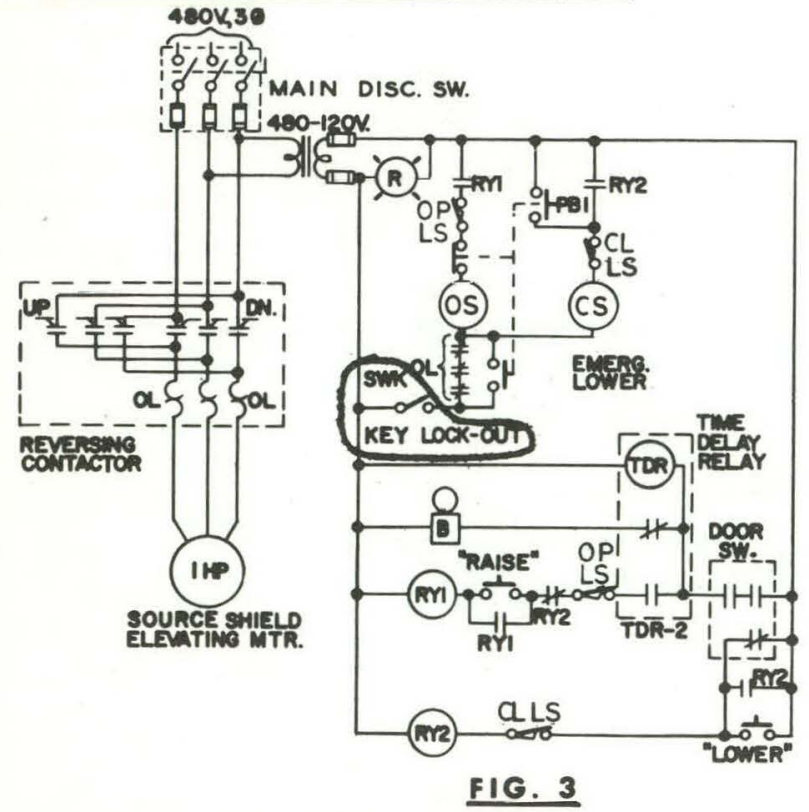

POSITION OF DOOR SWITCHES IN FIGURE 3 WILL BE AS SHOWN EXCEPT WHEN VAULT DOOR IS COMPLETELY CLOSED.
TWO POSITION SELECTOR SWITCH UNIT HEAVY DUTY OILTIGHT WITH MAINTAINED CONTACT BLOCK

1 N.O AND I N.C 6 AMP RATED CONTACTS, CYL INDER KEY LOCK' OPERATOR, KEY REMOVABLE IN LEFT POSITION'ONLY, ALLENBRADLEY RULLETIN 800T.

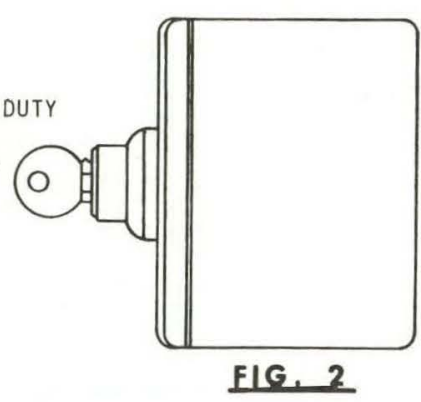

SHOWING KEY LOCK-OUT SWITCH SUITABLE FOR MOUNT ING APART FROM CONTROL CONSOLE.
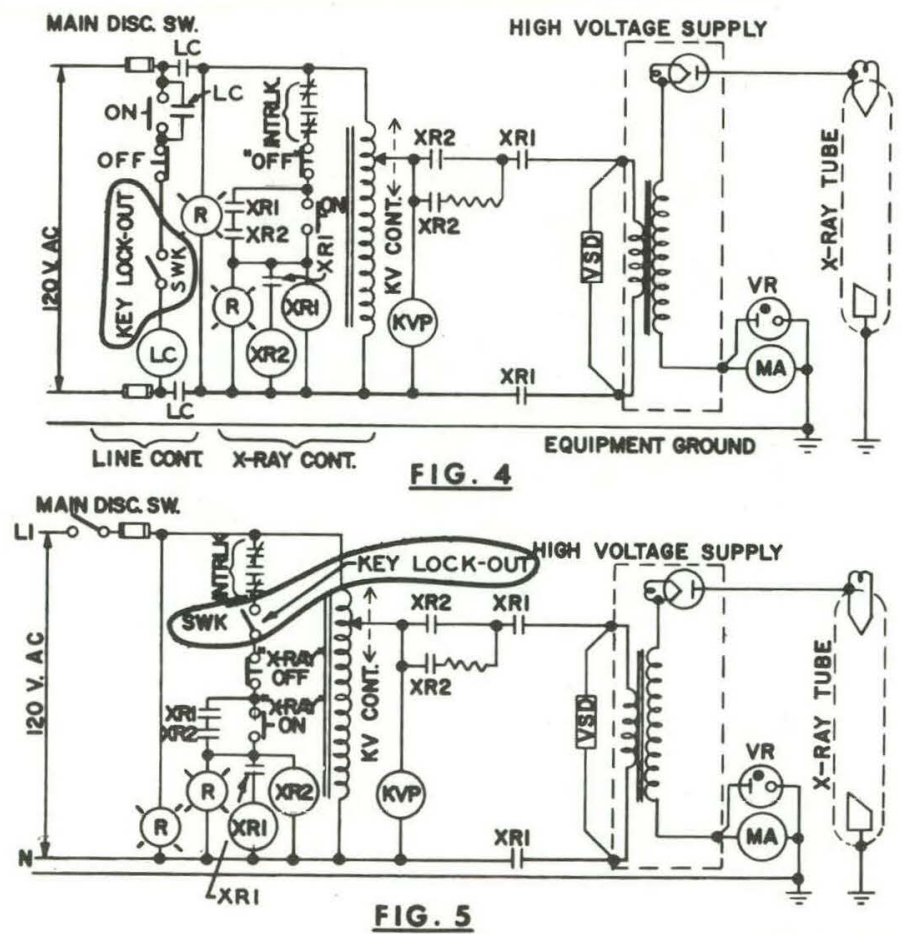
ELEMEMTARY DIAGRAMS OF TYPICAL CIRCUITS (CONT'D.)

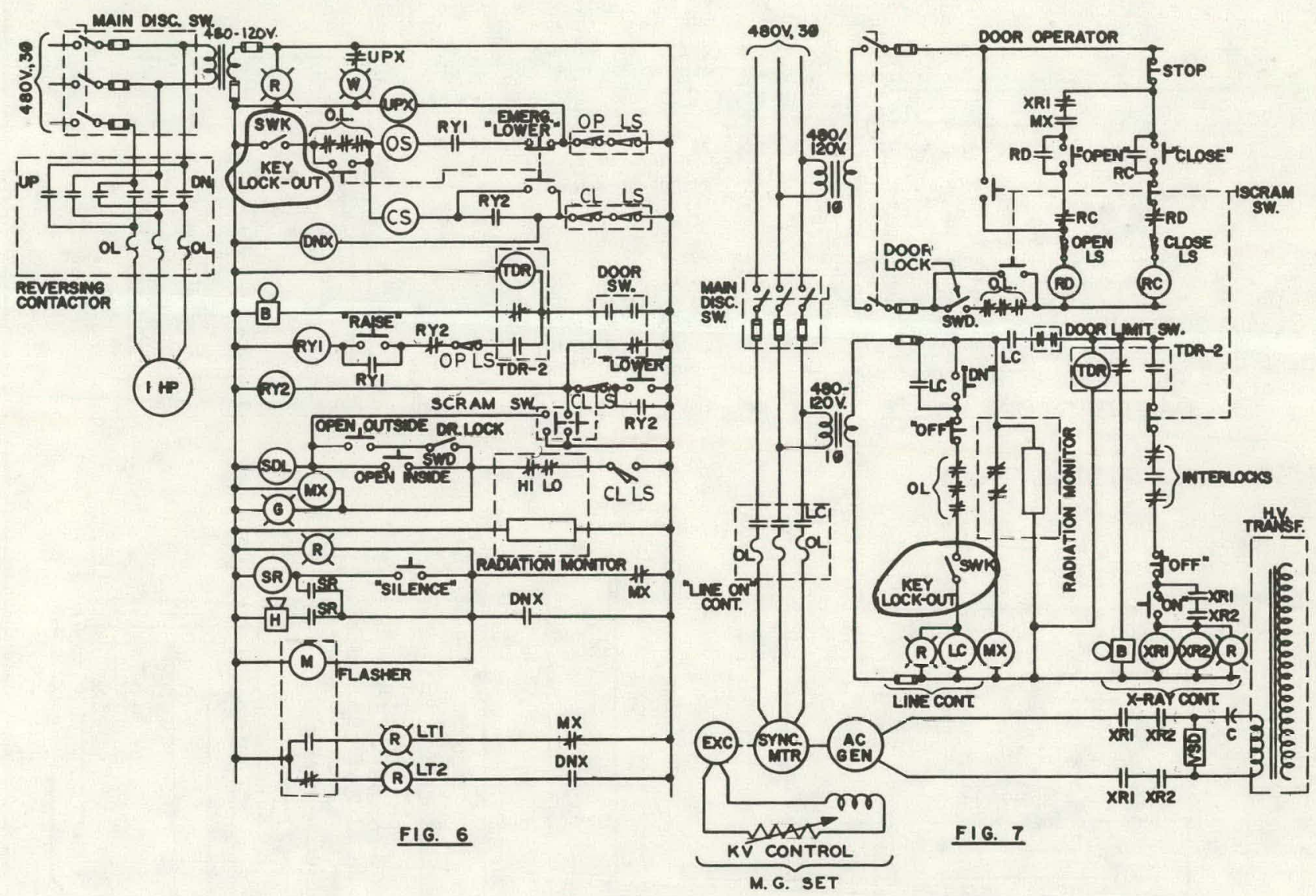


GENERAL

A FAIL STRIP INTERLOCK IS A RIBBON SWITCH, INSTALLED ON A WALL OR CEILING OR BARRICADE THAT DE-ENERGIZES THE SYSTEM IF IT IS BROKEN OR ACTIVATED BY PRESSURE.

SUCH A STRIP INTERL OCK SHALL BE INSTALLED WHERE THERE IS DANGER THAT THE TNTEGRITY OF VAULT, ROOM, OR OTHER ENCLOSURE MIGHT BE BREACHED INADVERTENTLY. FOR EXAMPLE, SUCH AN INTERLOCK SHALL BE USED ON A THIN-WALLED RÓOM ADJACENT TO A HEAYY

MAINTENANCE OR CONSTRUCTION AREA, OR WHÉRE ADJACENT TO FORK LIFT TRAFFIC.

\section{DESCRIPTION}

A FAIL STRIP DEVICE THAT COMPLIES WITH THIS STANDARD IS DESCRIBED IN THE FOLLOWING EXAMPLE. REFERENCE TO MATERIAL OR EQU IPMENT BY BRAND NAME, CATALOG NUMBER, OR NAME OF MANUFACTURER IS INTENDED TO BE DESCRIPTIVE, NOT RESTRICTIVE, AND IS
SOLELY FOR THE PURPOSE OF INDICATING TYPE OR QUALITY OF ITEM THAT IS ACCEPTABLE.

\section{COMPONENT IDENTIFICATION}

FSX - CONTROL RELAY, 120 VAC, DPDT, GUARD I AN TYPE 2200 U-DPDT-120

FS - RELAY, SENSITIVE, 5.17 VDC, 1950 OHM, WARD LEONARD TYPE 250-38.

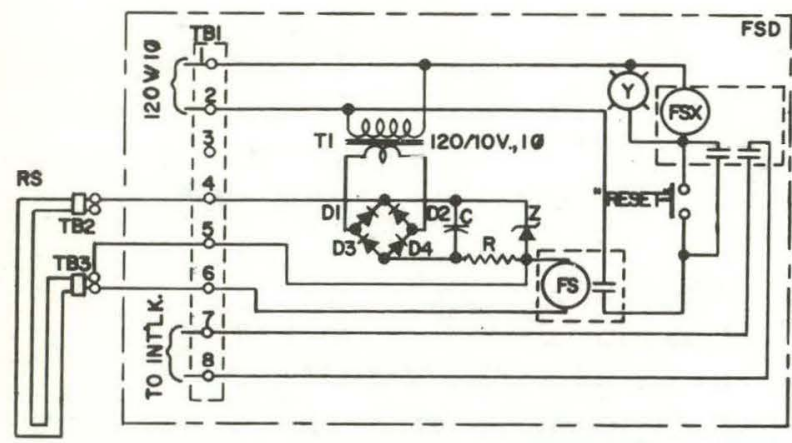

FIG. I: ELEMENTARY WIRING DIAGRAM

\section{ELEMENTARY DIAGRAMS OF TYPICAL CIRCUITS}
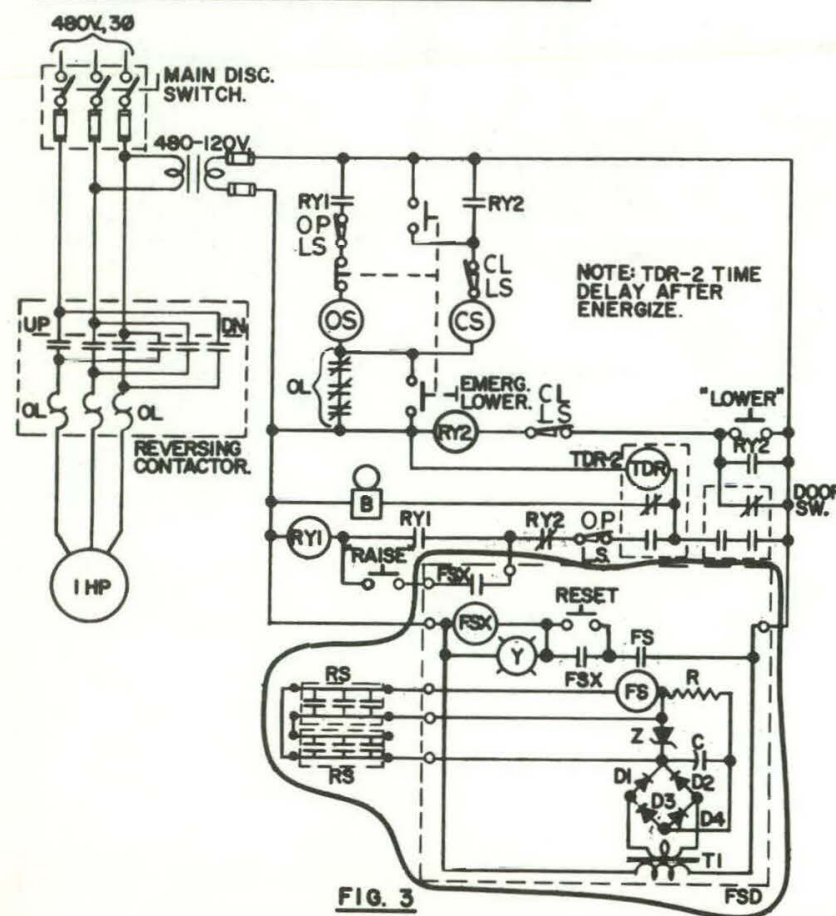

C - CAPACITOR, 100 MFD, $50 \mathrm{~V}$, MALLORY CO. TYPE TĆM.

D1, D2, D3, D4 - DIODE 500 MA, 500 V TYPE IN2071.

R- RESISTOR, $1 \mathrm{KOHM}, 1 \mathrm{~W}$, CARBON, ALLEN-BRADLEY CO. TYPE EB.

RS - RIBBON SWITCH MATERIAL PRESSURE ACTIVATED BY i2 OZ OR 40 OZ. PRESSURE, TAPESWITC CORPORATION OF AMERICA TYPE $102-B$.

TI - TRANSF ORMER, VOLTAGE , 5 VA, 120 VOLT PRIMARÝ 10 VOL'ं SECONDARY EDWARDS CO. TYPE 990.

TBI - TERMINAL, STRIP, 8 PT, 6-32 SCREWS, CINCH-IINNFS TŜ. TYPE $8-141$.

TB2, TB3 - TERMINAL, MOULDED, FOR FIG.2: SCHEMATIC DIAG. RIBBON SWITCH, TAPESWITCH CORPORATION OF AMERICA TYPE 103-B.

Z - ZENER DIODE, $5.6 \mathrm{~V}, 0.4 \mathrm{~W}$, TYPE IN $752 \mathrm{~A}$.
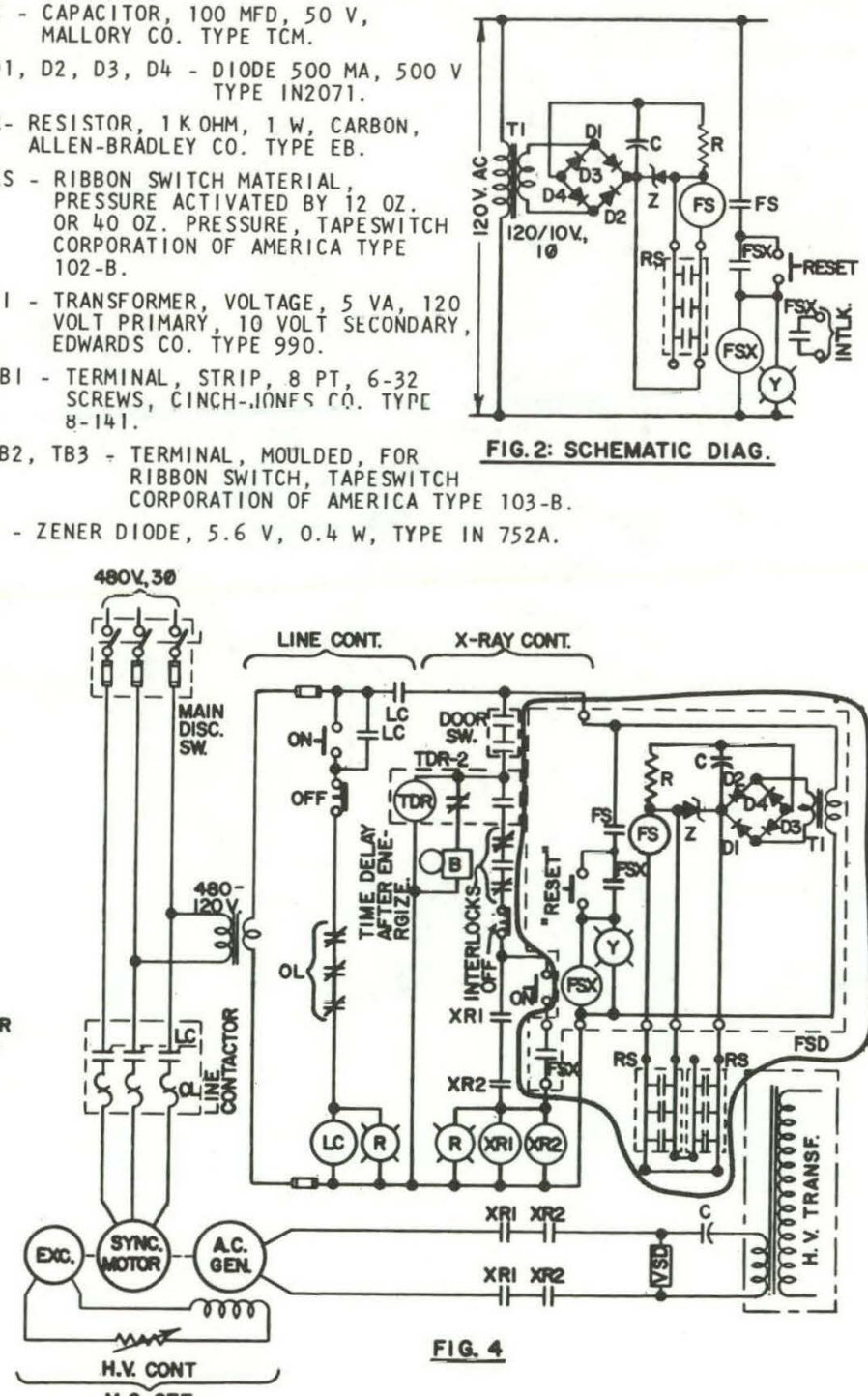

M.G. SET 


\section{General}

Signs as described in this standard are prepared as visual warning devices to be used in and around radiation producing systems to warn personnel of radiation hazards. Specifying the number, kind, and location of warning signs will be the responsibility of the group in charge of the facility with assistance from the Radiation Safety Department.

All warning signs shall include (a) an approved heading that indicates the relative hazard, (b) a statement of the type of hazard, (c) a statement ur actlon requlred in the area, (d) a prominently displayed three-bladed reddish purple propeller radiation symbol on a yellow background.

Warning signs for radiation hazards shall be divided into two classifications as follows:

\section{Danger Signs}

Danger signs shall be used where exposure of personnel could result in injurious doses of radiation. The heading of this sign states "Danger" in white letters on a red oval edged with a rectangular black border. The body is white and the message is black. The sign will also display a prominent three-bladed reddish purple propeller radiation symbol on a yellow background.

\section{Caution Signs}

Caution signs shall bc uscd where exposure can result in exceeding radiation protection guide values but unlikely to cause clinically detectable injurious doses to personnel. The heading of this sign states "Caution" in yellow letters on a black rectangle. The body is yellow and the message is black. The sign will also display a prominent three-bladed reddish purple propeller radiation symbol.

\section{Description}

All warning signs shall be fabricated of $1 / 16$-inch-thick aluminum. They shall be furnished with rounded or blunt corners and shall be free from sharp edges, burl's, or other projeclions. Fastening devices shall be installed in such a way that they do not constitute a hazard.

The "Danger" signs shall have a white background of a dry adhesive sheeting (3M Co. Scotchcal film \#650 white). The background for the standard radiation symbol shall be a dry adhesive sheeting (3M Co. Scotchcal film \#652 yellow). The colors red, black, and reddish purple shall be a gloss vinyl ink ( Naz-Dar Co. red \#GV-109, black \#GV-111, and reddish purple \#GV-13349). The standard proportions of the sign shall be as shown in Table 1. 
The "Caution" signs shall have a yellow background of a dry adhesive sheeting ( $3 \mathrm{M}$ Co. Scotchcal film \#652 yellow). The colors black and reddish purple shall be a gloss vinyl ink (Naz-Dar Co. black \#GV-111, and reddish purple \#GV-13349). The standard proportions of the sign shall be as shown in Table 2.

Examples of signs are shown in Figures 1 through 5.

When conditions warrant the use of a sign size not covered in these standards, the ratio of the depth of the identifying panel (Danger or Caution) to the width of the sign shall be as established in Tables 1 and 2 . The size of lettering to be used for the wording of the sign or message should be as large as possible but consistent with good balance and legibility. Block-style lettering should be used.

The method of dimensioning, design, and orientation of the standard threebladed radiation symbol (one blade pointed downward and centered on the vertical axis) shall be executed as shown in Figure 6. 
Reference to material or equipment by brand name, catalog number, or name of manufacturer is intended to be descriptive, not restrictive, and is solely for the purpose of indicating type of quality of item that is acceptable.

Table 1

STANDARD PROPORTIONS FOR DANGER SIGNS

\begin{tabular}{|c|c|c|c|c|c|c|c|c|c|c|}
\hline \multicolumn{3}{|c|}{$\begin{array}{l}\text { Sign Size } \\
\text { Inches }\end{array}$} & \multicolumn{3}{|c|}{$\begin{array}{c}\text { Black Rectangular } \\
\text { Panel, Inr.hes } \\
\end{array}$} & \multicolumn{3}{|c|}{$\begin{array}{l}\text { Red Oval } \\
\text { Inches }\end{array}$} & \multirow{2}{*}{$\begin{array}{c}\text { Word Danger } \\
\text { Height of } \\
\text { Letter } \\
\text { Inches }\end{array}$} & \multirow{2}{*}{$\begin{array}{c}\text { Maximum Space } \\
\text { Available for } \\
\text { Sign Wording } \\
\text { Inches }\end{array}$} \\
\hline Height & & Width & Height & & Width & Height & & Width & & \\
\hline \multicolumn{11}{|c|}{ HORIZONTAL PATTERN } \\
\hline 7 & $x$ & 10 & $31 / 4$ & $x$ & $93 / 8$ & $27 / 8$ & $x$ & $81 / 2$ & $17 / 16$ & $23 / 4 \times 93 / 8$ \\
\hline 10 & $x$ & 14 & $45 / 8$ & $x$ & $133 / 8$ & $41 / 8$ & $x$ & $117 / 8$ & $21 / 16$ & $41 / 4 \times 133 / 8$ \\
\hline 14 & $x$ & 20 & $61 / 2$ & $x$ & $193 / 8$ & $53 / 4$ & $x$ & 17 & $27 / 8$ & $61 / 4 \times 193 / 8$ \\
\hline 20 & $x$ & 28 & $91 / 4$ & $x$ & $273 / 8$ & $81 / 4$ & $x$ & $237 / 8$ & $41 / 8$ & $91 / 2 \times 273 / 8$ \\
\hline \multicolumn{11}{|c|}{ UPRIGHT PATTERN } \\
\hline 10 & $x$ & 7 & $23 / 8$ & $x$ & $63 / 8$ & $21 / 8$ & $x$ & $57 / 8$ & $11 / 16$ & $63 / 8 \times 63 / 8$ \\
\hline 14 & $x$ & 10 & $31 / 4$ & $x$ & $93 / 8$ & $27 / 8$ & $x$ & $81 / 2$ & $17 / 16$ & $91 / 2 \times 93 / 8$ \\
\hline 20 & $x$ & 14 & $45 / 8$ & $x$ & $133 / 8$ & $41 / 8$ & $x$ & $117 / 8$ & $21 / 16$ & $\times 133 / 8$ \\
\hline 28 & $x$ & 20 & $61 / 2$ & $x$ & $193 / 8$ & $53 / 4$ & $x$ & 17 & $27 / 8$ & $201 / 4 \times 193 / 8$ \\
\hline
\end{tabular}

Examples of signs are shown in Figs. 1-5. 
Table 2

STANDARD PROPORTIONS FOR CAUTION SIGNS

\begin{tabular}{|c|c|c|c|c|c|c|c|}
\hline \multicolumn{3}{|c|}{$\begin{array}{l}\text { Sign Size } \\
\text { Inches }\end{array}$} & \multicolumn{3}{|c|}{$\begin{array}{c}\text { Black Rectangular } \\
\text { Panel, Inches }\end{array}$} & \multirow{2}{*}{$\begin{array}{l}\text { Word Caution } \\
\text { Height of } \\
\text { Letter } \\
\text { Inches }\end{array}$} & \multirow{2}{*}{$\begin{array}{c}\text { Maximum Space } \\
\text { Available for } \\
\text { Sign Wording } \\
\text { Inches }\end{array}$} \\
\hline Height & & Width & Height & & Width & & \\
\hline \multicolumn{8}{|c|}{ HORIZONTAL PATTERN } \\
\hline 7 & $x$ & 10 & $21 / 4$ & $x$ & $93 / 8$ & $15 / 8$ & $31 / 4 \times 93 / 8$ \\
\hline 10 & $x$ & 14 & $31 / 4$ & $x$ & $133 / 8$ & $21 / 4$ & $51 / 2 \times 133 / 8$ \\
\hline 14 & $x$ & 20 & $33 / 4$ & $x$ & $193 / 8$ & $23 / 4$ & $\times 193 / 8$ \\
\hline 20 & $x$ & 28 & $41 / 4$ & $x$ & $273 / 8$ & $31 / 4$ & $141 / 2 \times 273 / 8$ \\
\hline \multicolumn{8}{|c|}{ UPRIGHT PATTERN } \\
\hline 10 & $x$ & 7 & $15 / 8$ & $x$ & $63 / 8$ & $11 / 8$ & $\times \quad 63 / 8$ \\
\hline 14 & $x$ & 10 & $21 / 4$ & $x$ & $93 / 8$ & $15 / 8$ & $101 / 2 \pi 93 / 8$ \\
\hline 20 & $x$ & 14 & $31 / 4$ & $x$ & $133 / 8$ & $21 / 4$ & $151 / 2 \times 133 / 8$ \\
\hline 28 & $x$ & 20 & $33 / 4$ & $x$ & $193 / 8$ & $23 / 4$ & $24 \times 193 / 8$ \\
\hline
\end{tabular}

Examples of signs are shown in Figs. 1-5. 


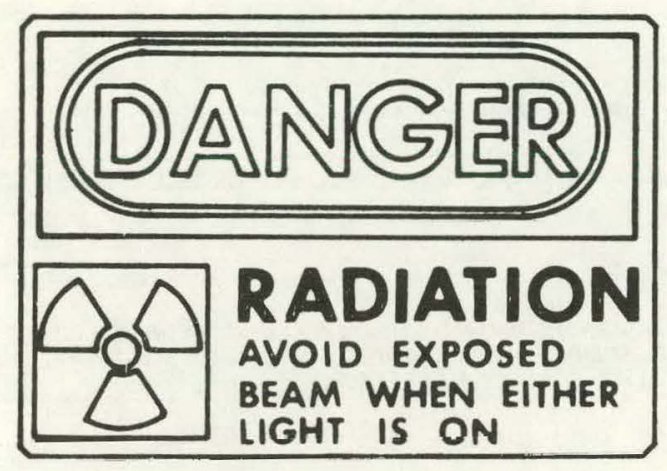

FIG. $1(7 \times 10)$

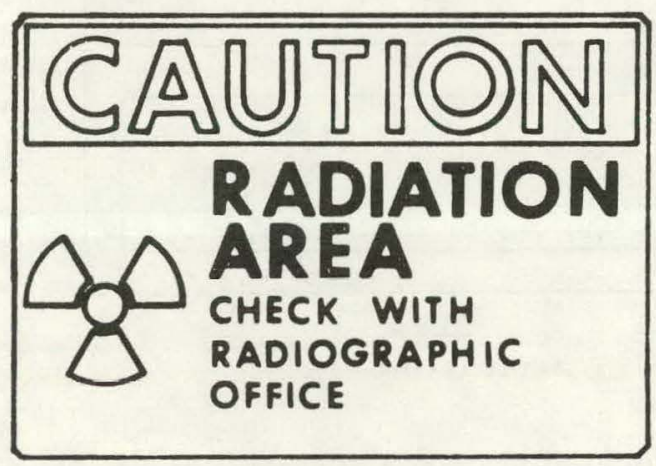

FIG. $3(14 \times 20)$

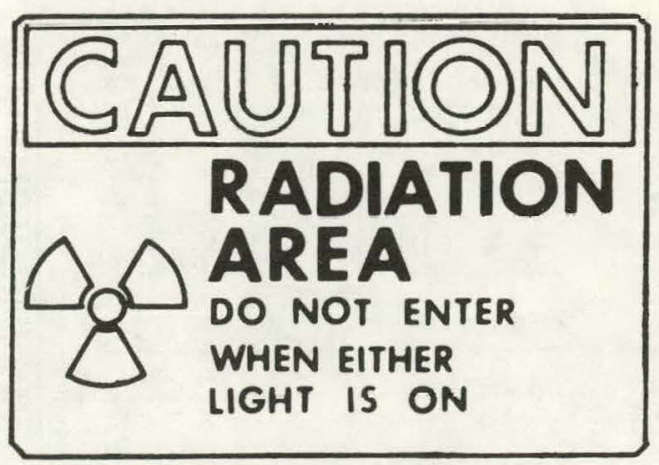

FIG. $5(14 \times 20)$

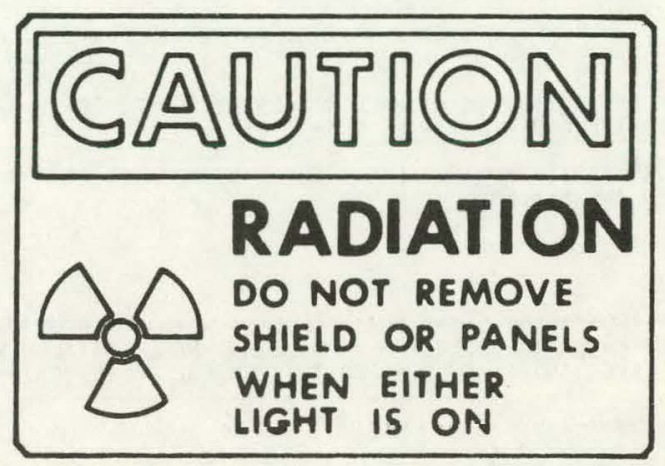

FIG. $2(7 \times 10)$

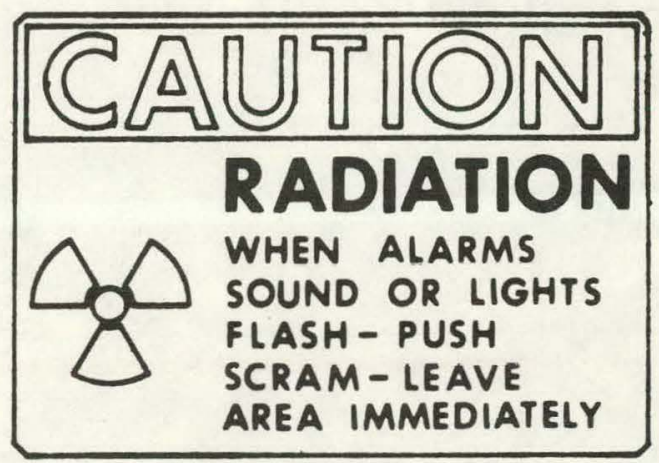

FIG. $4(14 \times 20)$

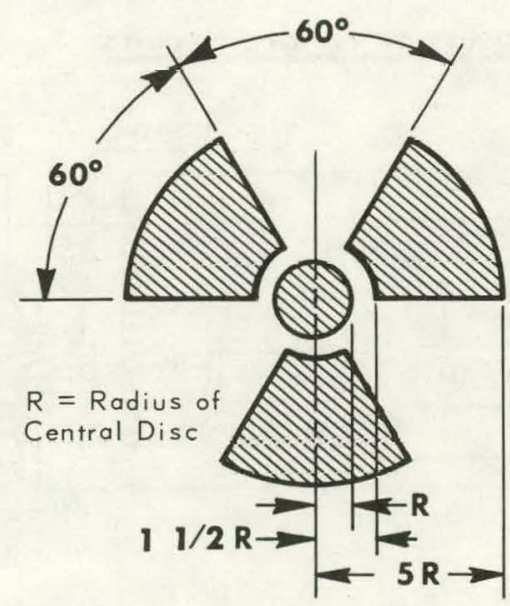

FIG. 6 
GENERAL

A "LINE ON" INDICATION IS A SMALL RED LIGHT CONNECTED IN THE SYSTEM CONTROL CIRCUIT SUCH THAT WHEN THE "POWER ON" SWITCH IS ENERGIZED THE RED LIGHT WILL BURN STEADILY.

THE "LINE ON" INDICATING RED LIGHT SHALL BE MOUNTED ON THE CONTROL PANEL AND BE ENERGIZED WHEN OPERATING VOLTAGE IS MADE AVAILABLE TO THE SYSTEM.

\section{DESCRIPTION}

A "LINE ON" INDICATING LIGHT THAT COMPLIES WITH THE REQUIREMENTS OF THIS STANDARD IS SHOWN IN THE FOLLOWING EXAMPLE. REFERENCE TO MATERIAL OR EQUIPMENT BY BRAND NAME, CATALOG NUMBER, OR NAME OF MANUFACTURER IS INTENDED TO BE DESCRIPTIVE, NOT RESTRICTIVE, AND IS SOLELY FOR THE PURPOSE OF INDICATING THE OUALITY OF ITEM THAT IS ACCEPTABLE.

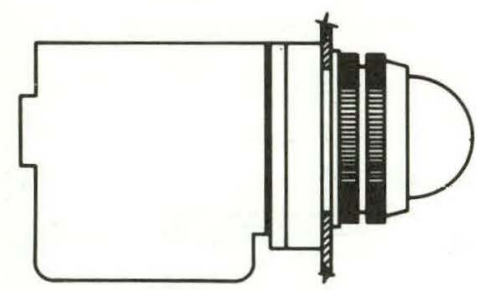

FIG I

PILOT LIGHT, TRANSFORMER TYPE,

120 VOLTS, $60 \mathrm{HZ}$, WITH A RED

COLOR CAP ALLEN-BRADLEY,

BULLETIN 800T.

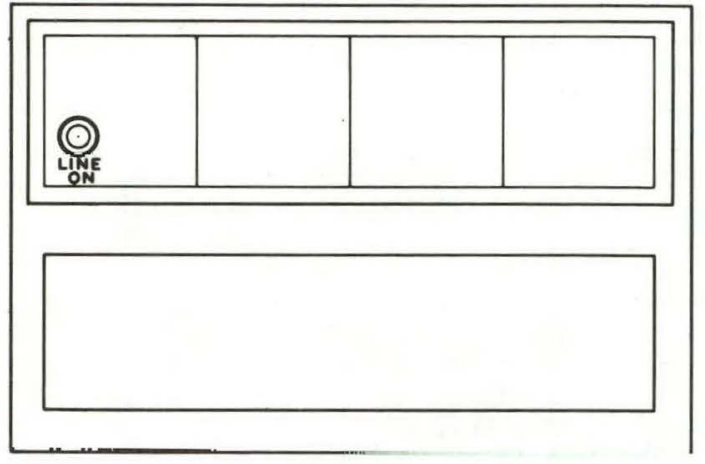

FIG. 2

SAMPLE CONTROL PANEL

ELEMENTARY DIAGRAMS OF TYPICAL CIRCUITS

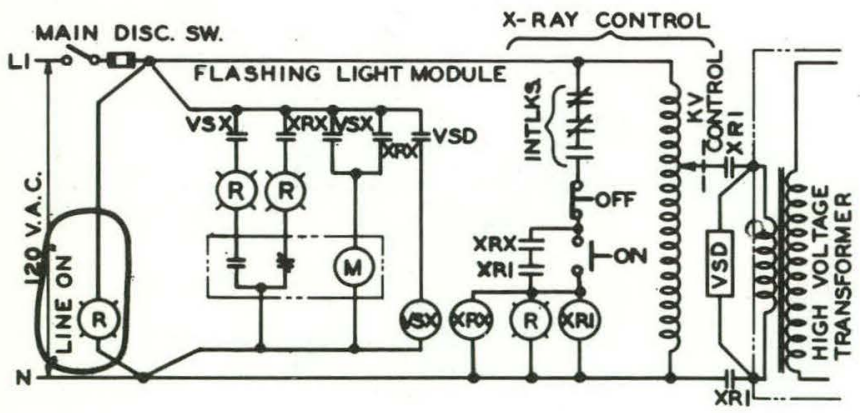

FIG. 3

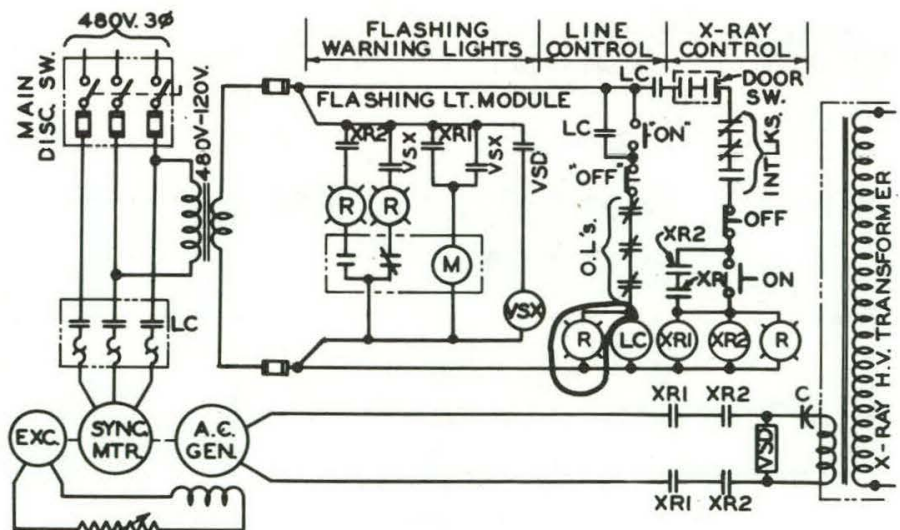

KV CONTROL

M.G. SET

FIG. 4 
GENERAL

A "SYSTEM ARMED" INDICATION IS A SMALL AMBER LIGHT CONNECTED IN THE SYSTEM CONTROL CIRCUIT SUCH THAT WHEN THE RADIATION SOURCE IS READY TO BE ENERGIZED THE AMBER LIGHT WILL BURN STEADILY.

THE "SYSTEM ARMED" INDICATING AMBER LIGHTं SHALL BE MOUNTED ON THE CONTROL PANEL AND BE ENERGIZED WHEN ALL "SYSTEM ON" REQUIREMENTS HAVE BEEN SATISFIED EXCEPT FOR DEPRESSING THE "X-RAY ON" OR "SOURCE EXPOSED" PUSHBUTTON.

\section{DESCRIPTION}

A "SYSTEM ARMED" INDICATING LIGHT THAT COMPLIES WITH THE REQUIREMENTS OF THIS STANDARD IS SHOWN IN THE FOLLOWING EXAMPLE. REFERENCE TO MATERIAL OR EQUIPMENT BY BRAND NAME, CATALOG NUMBER, OR NAME OF MANUFACTURER IS INTENDED TO BE DESCRIPTIVE, NOT RESTRICTIVE, AND IS SOLELY FOR THE PURPOSE OF INDIICATING THE QUALIITY OF ITEM THAT IS ACCEPTABLE.

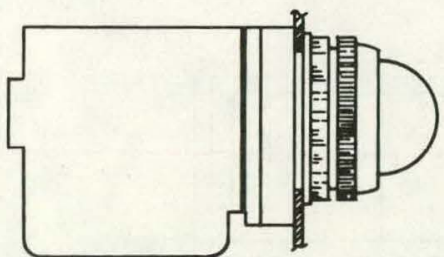

FIG. 1

PILOT LIGHT, TRANSFORMER TYPE, 120 VOLTS 60 HZ, WITH AN AMBER-COLOR CAP ALLENBRADLÉY, BULLETIN 800T.

ELEMENTARY DIAGRAMS OF TYPICAL CIRCUITS

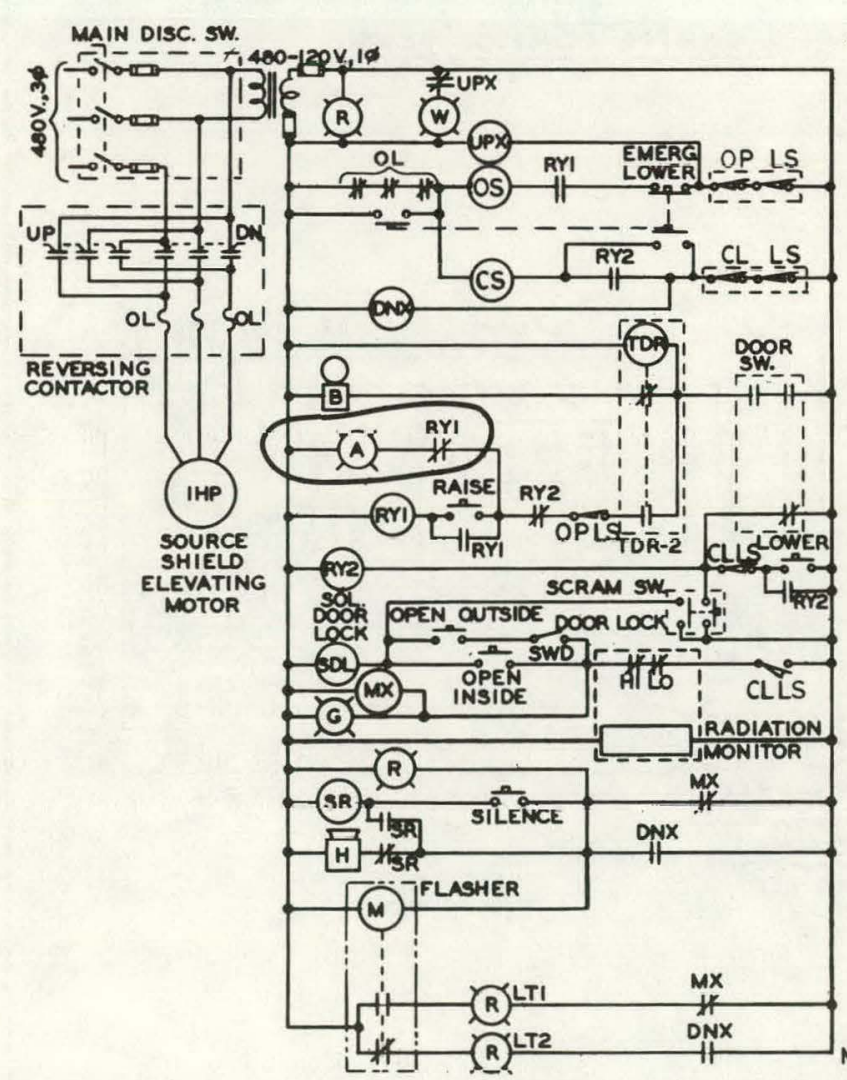

FIG. 3

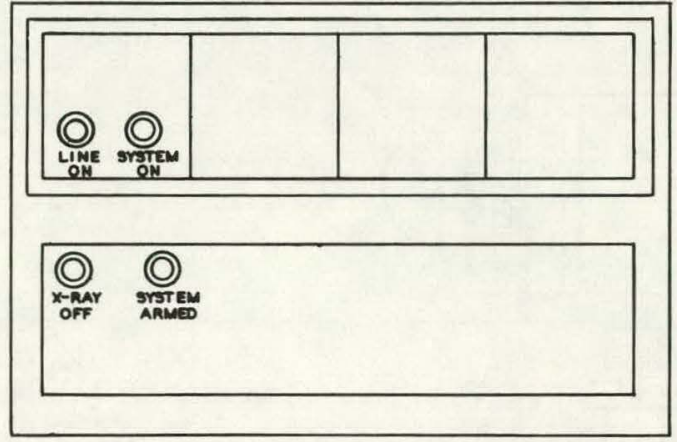

SAMPLE CONTROL PANEL

MAIN DISC SW.

$\int_{1}^{1} 1100-1400-128 \mathrm{v} .14$

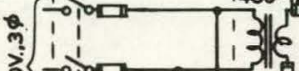

की
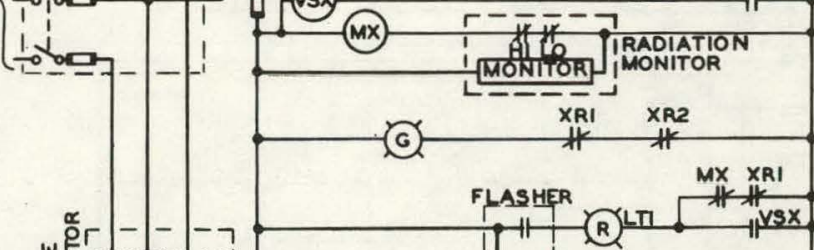

w.

殁

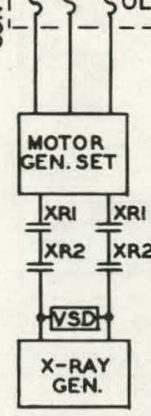

R $L T 2, \ldots X R 1$ SEE SOLNX $11-$ \#VSX
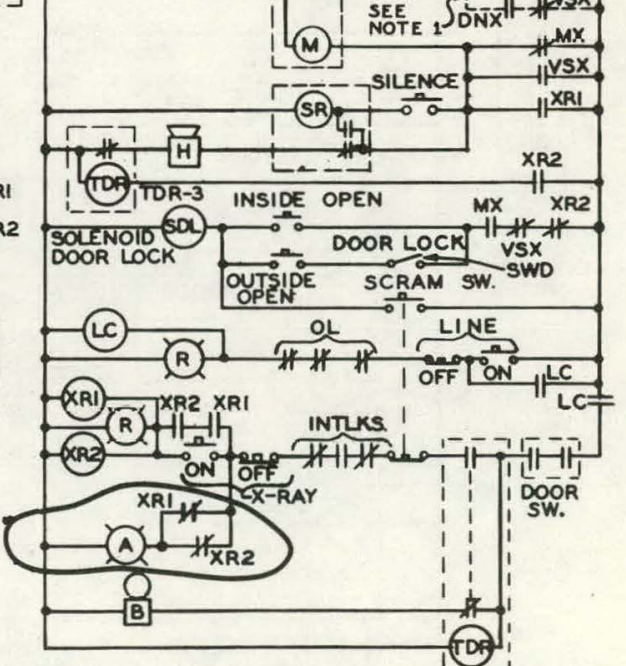
NOTES: 1. ADD CIRCUIT IN DASHED LINES $\quad$ FIG. 4 IN SAME FACILITY AS X-RAY. 


\section{GENERAL}

A "SYSTEM ON-STEADY" INDICATION IS A SMALL RED OR MAGENTA LIGET CONNECTED IN THE SYSTEM CONTROL CIRCUIT SUCH THAT WHEN THE RADIATION SOURCE IS ENERGIZED THE RED OR MAGENTA LIGHT WILL BURN STEADY.

THE "SYSTEM ON-STEADY" INDICATING RED OR MAGENTA LIGHT SHALL BE MOUNTED ON THE CONTROL PANEL AND BE ENERGIZED WHEN X-RAY HIGH YOLTAGE AND/OR SOUREE EXPOSED SYSTEM IS ENERGIZED.

\section{DESCRIPTION}

A "SYSTEM ON-STEADY" INDICATING LIGHT THAT COMPLIES WITH THE REQUIREMENTS OF THIS STANDARD IS SHOWN IN THE FOLLOWING EXAMPLE. REFERENCE TO MATERIAL OR EQUIPMENT BY BRAND NAME, CATALOG NUMBER, OR NAME OF MANUFACTURER IS INTENDED TO BE DESCRIPTIVE, NOT RESTRICTIVE, AND IS SOLELY FOR THE PURPOSE OF INDICATING THE QUALITY OF I TEM THAT IS ACCEPTABLE.

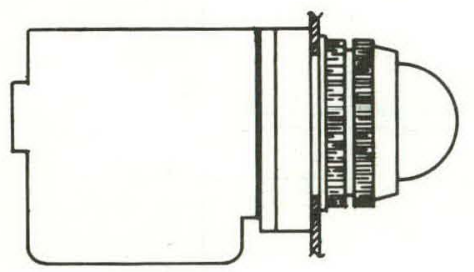

FIG. 1

PILOT LIGHT, TRANSFORMER TYPE, 120 VOLTS, 60 HZ, WITH A RED OR MAGENTA COLOR
BULLETIN $800 T$.

ELEMENTARY DIAGRAMS OF TYPICAL CIRCUITS

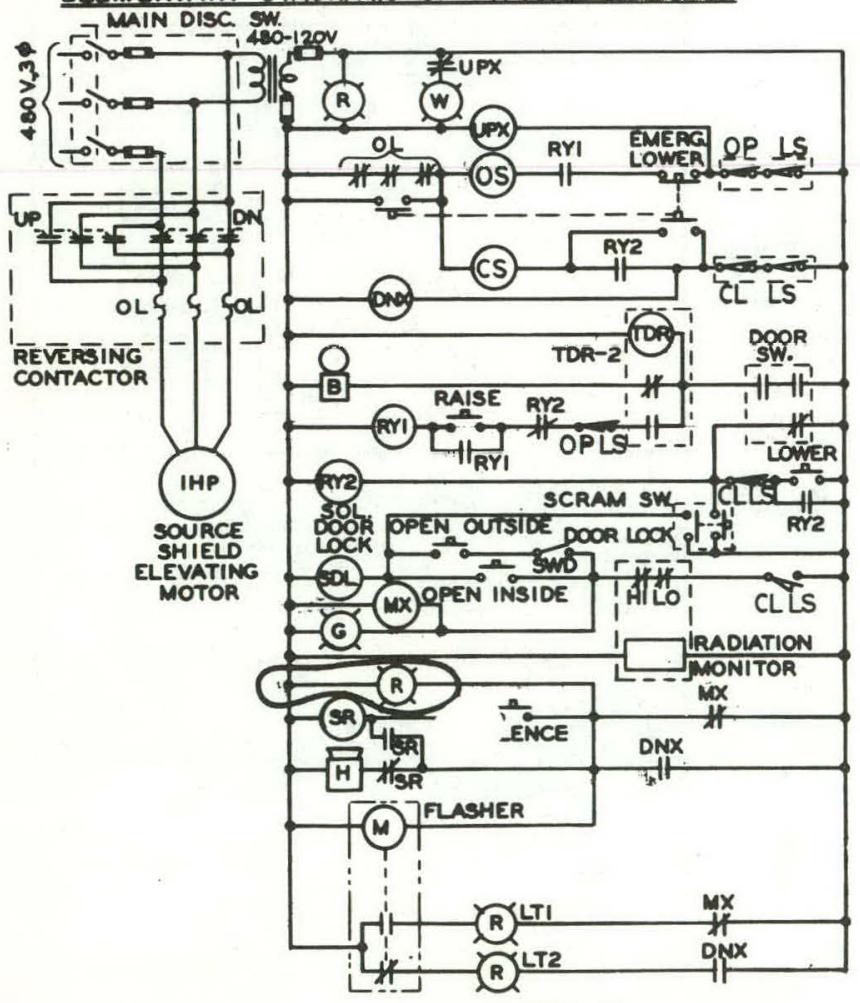

FIG. 3

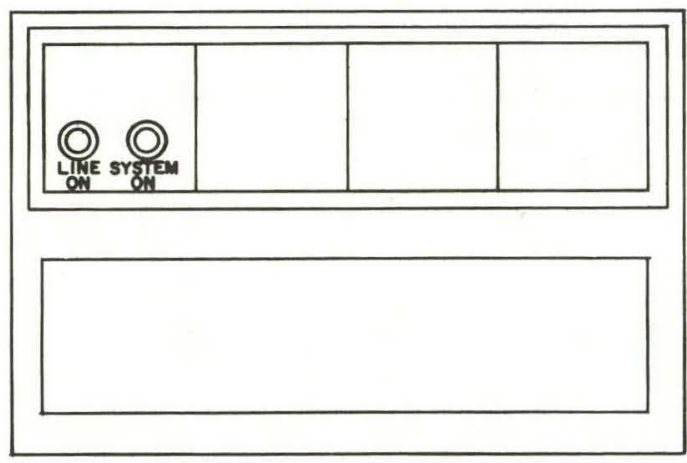

FIG. 2

SAMPLE CONTROL PANEL

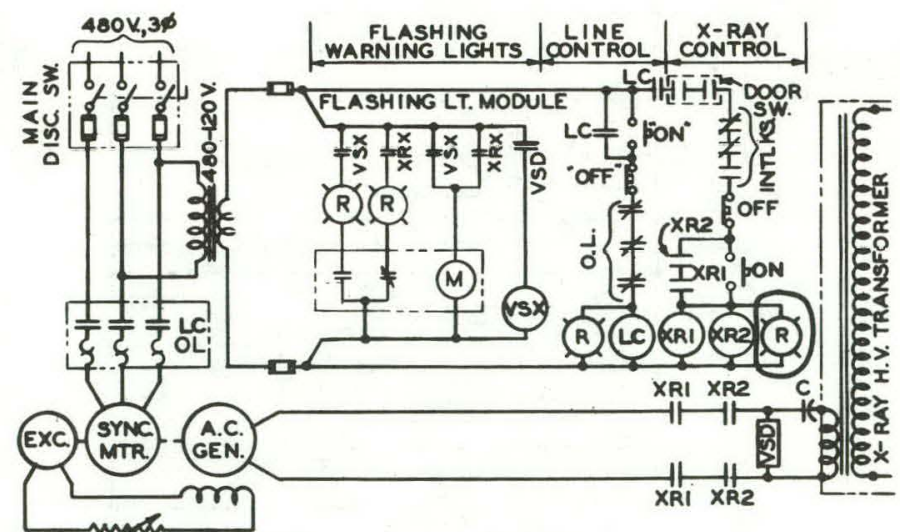

FIG. 4 
GENERAL

A "SYSTEM ON-FLASHING" INDICATION IS A RER OR MAGENTA* LIGHT CONNECTED IN THE SYSTEM CONTROL CIRCUIT SUCH THAT WHEN THEN RADIATION SOURCE IS ENERGIZED THE REB OR MAGENTA LIGHT WILL BE CYCLED ON AND OFF BY A FLASHER UNIT.

THE "SYSTEM ON-FLASHING" INDICATING RED OR MAGENTA LFGHT SHALL BE MOUNTED IN DUAL ARRANGEMENT WITH A LIGHT WHICH IS DESCRIBED IN ENG INEERING STANDARD $Y$-ES-1.9-38 THIS LIGHT SHALL BE MOUNTED APPROXIMATELY AT EYE LEVEL IN THE WORK AND/OR RADIATION AREA SO AS TO WARN PERSONNEL OF THE EXISTING RADIATION HAZARD. THIS LIGHT WILL BE FLASHING WHILE THE X-RAY CONTACTOR(S) IS CLOSED AND/OR THE RADIOACTIVE SOURCE IS EXPOSED, IF USED. THE FLASHING LIGHT IS REQUIRED ON ALL X-RAY ONITS
AND ON ALL SOURCE FACILITIES WHICH ARE ELECTRICALLY ACTLATED.

(*) USE RED LIGHT PENDING REVISION OF ANSI 253.1-1967 AND HEW MORP 68-14.

\section{DESCRIPTION}

A "SYSTEM ON-FLASHING" INDICATING LIGHT THAT COMPLIES WITH THE REQUIREMENTS OF THIS STANOARD IS SHOWN IN THE FOLLOWING EXAMPLE. REFERENCE TO MATERIAL OR EQUIPMENT BY BRAND NAME, CATALOG NUMBER OR NAME OF MANUFACTURER IS INTENDED TO BE DESCRIPTIVE, NOT RESTRICTIVE, AND IS SOLELY FOR THE PURPOSE OF INDICATING THE QUALITY OF ITEM THAT IS ACCEPTABLE.

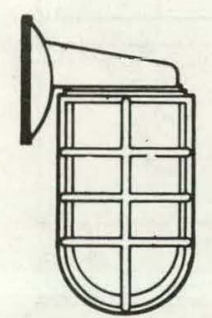

INCANDE SCENT LIGHT FIXTURE, VAPORTIGHT,

FOR WALL MOUNT ING ON A FOUR-INCH BOX.

FIXTURE SHALL HAVE RED OR MAGENTA GLOBE,

ELECTRIC PROD. CO. TYPE VW-IG-PG.

ELEMENTARY DIAGRAMS OF TYPICAL CIRCUITS

$$
\text { है }
$$

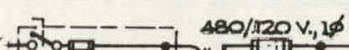

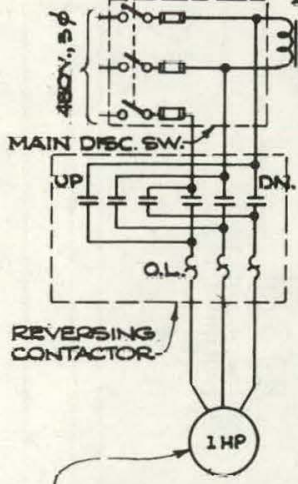

Source SHIEld

movatine

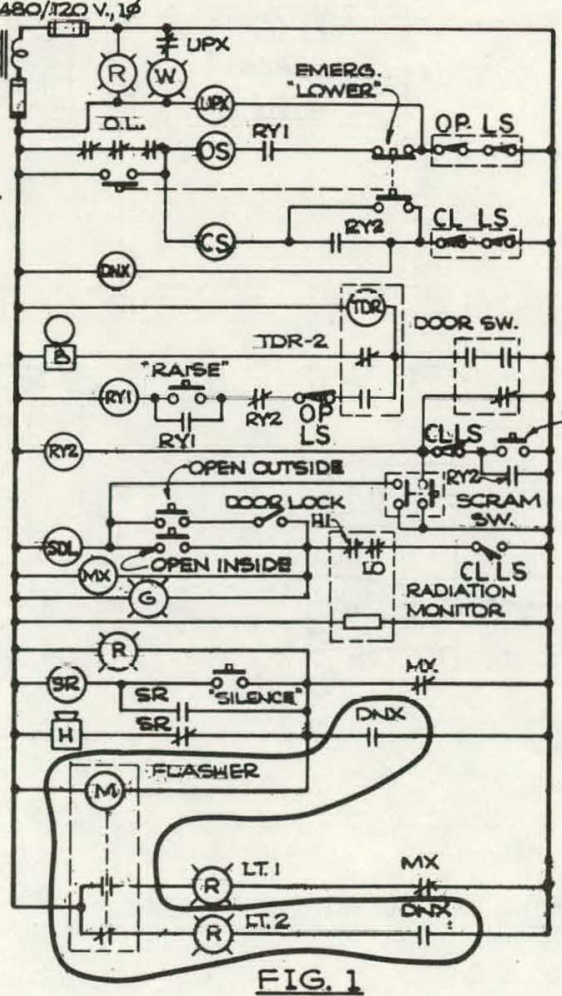

REPEAT CYCLE TIMER, CAM ACTUATED, SINGLE SWITCH WITH SPDT CONTACT ACTION, RATED 20 A. AT 125 V. CAM SHAFT SPEED $7-1 / 2$ SEC/REV. CAM TO ACTUATE SWITCH CAM TO ACGTUATE SWITCH HAYDON SW. AND INSTR. CO. HAYDON SERIES RG21.
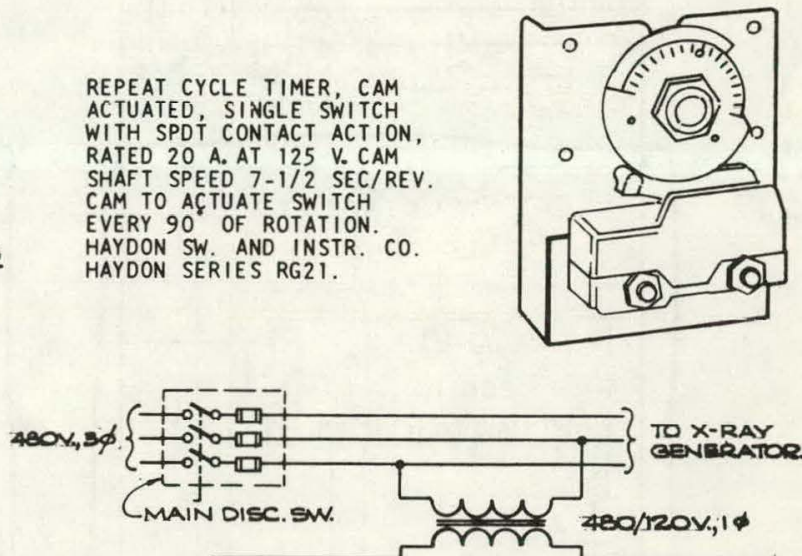

"LOWER"

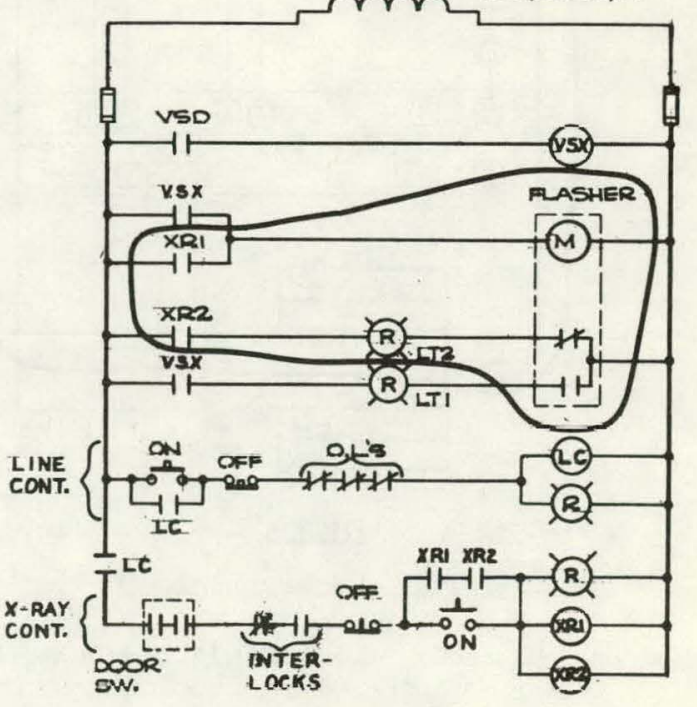

FIG. 2 
ELEMENTARY DLAGRAMS OF TYPICAL CIRCIUISS CONT.

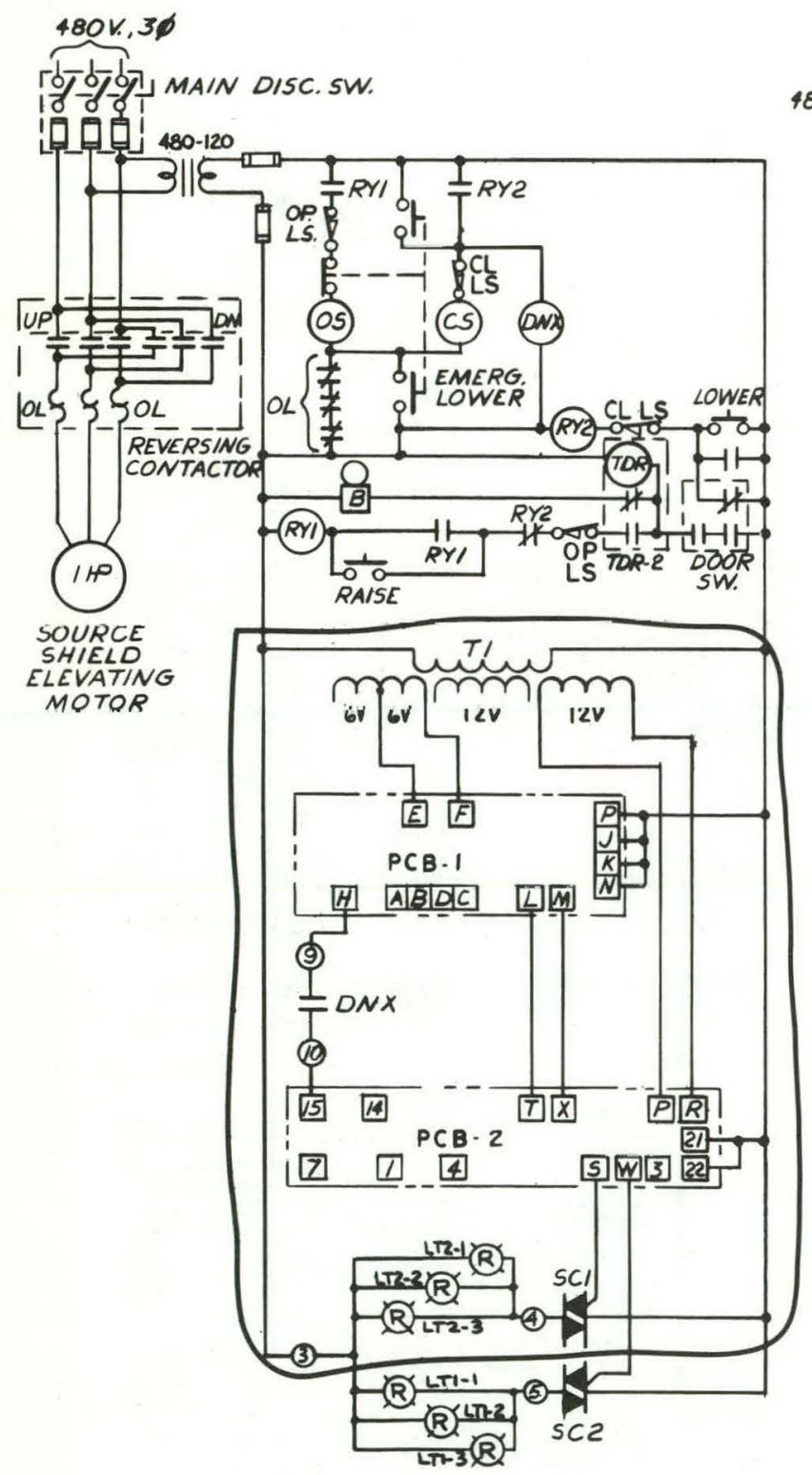

EIGURE 3

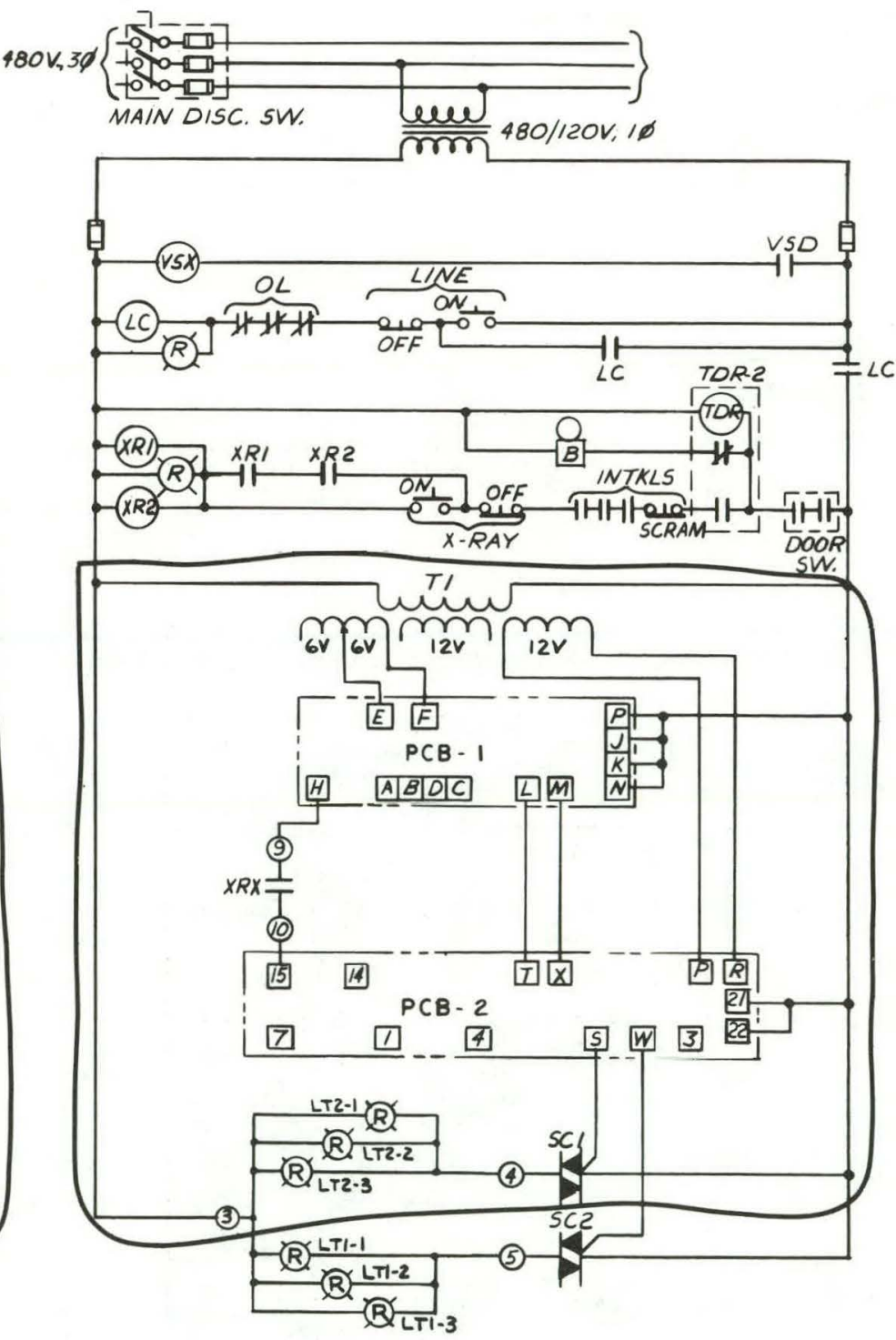

EIGURE 4

(FOR INSTALLATION WITH MORE THAN THO SETS OF 120 VOLT, 100 WATT FLASHING LAMPS,) 
DESCRIPTION

A "SYSTEM ON FLASHING" INDICATING LIGHT FOR USE WITH ANALYTICAL X-RAY EQUIPMENT THAT COMPLIES WITH THE REQUIREMENTS OF THIS STANDARD IS SHOWN IN THE FOLLOWING EXAMPLE. REFERENCE TO MATERIAL OR EQUIPMENT BY BRAND NAME, CATALOG NUMBER, OR NAME OF MANUFACTURER IS INTENDED TO BE DESCRIPTIVE, NOT RESTRICTIVE, AND IS SOLELY FOR THE PURPOSE OF INDICATING THE QUAL ITY OF ITEM THAT IS ACCEPTABLE. (REF. UCC-ND ENGR. DWGS. C-E-31158 AND C-E-31159.)

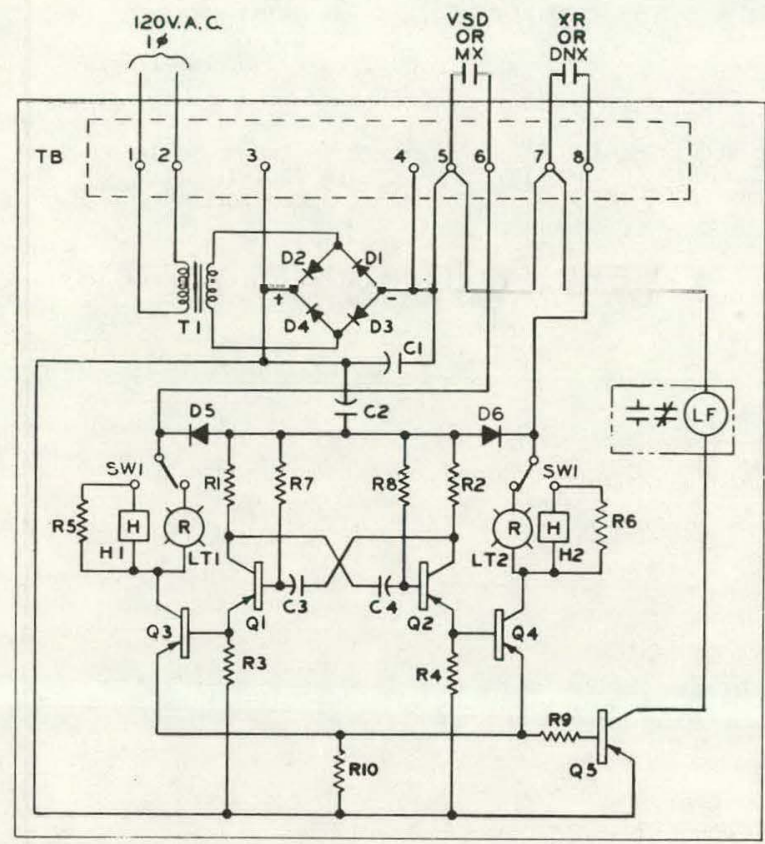

FIG. I ELEMENTARY WIRING DIAGRAM

PCB-1
T1

$D 1-D 6$

Q1-Q2

Q3-Q5

LF

$\mathrm{C} 1-\mathrm{C} 2$

C3-C4

$R 1-R 4$

R5 - R6

R7-R8

R9

R10

LT1-LT2

$\mathrm{H} 1-\mathrm{H} 2$

SW1

TB
FILAMENT TRANSF ORMER, PRI. 117 VOLTS, 60 CYCLES, SEC. 6.3 VOLTS CT AT 1.2 AMPS. THORDARSON $21 F 08$.

DIODE, SILICON, TEXAS IN207I.

TRANSISTOR, GERMANIUM, PNP, 2N2084 AMPEREX.

TRANSISTOR, TEXAS 2 NS26.

DRY REED RELAY, DPDT CONTACTS RATED 10 VA AT 0.5 AMP COIL VOLTS 6 VÓC, COIL RESISTANCE 50 OHMS, MAGNEREED W103PCX-5, MAGNECRAFT ELECT. CO.

CAPACITOR, FIXED, DRY ELECTROLYTIC, 1000 MFD, 15 VDC, MAI I $\cap R Y$

CAPACITOR, FIXED, DRY ELECTROLYTIC, 50 MFD, 50 VDC, MALLORY.

RESISTOR, COMP. CARBON, FIXED, $1 / 2$ WATT, 2400 OHMS, ALLEN-BRADLEY.

RESISTOR, COMP. CARBON, FIXED, 1 WATT, 27 OHMS, ALLEN-BRADLEY.

RESISTOR, COMP. CARBON, FIXED, 1/2 WATT, 27,000 OHMS, ALLEN-BRADLEY.

RESISTOR, COMP. CARBON, FIXED, $1 / 2$ WATT, 5100 OHMS, ALLEN-BRADLEY.

RESISTOR, COMP. CARBON, FIXED, 1/2 WATT, 7.5 OHM, ALLEN-BRADLEY.

PILOT LIGHTT ASSEMBLY, RED LUCITE LENS, FOR T3-1/4 MBB \#47 LAMP, $E$. $F$. JOHNSON CO.

SONALERT ELECTRONIC AUDIBLE SIGNAL, $2800 \mathrm{HZ}, 6-28$ VOLTS D.C. , MALLORY SC628.

SWITCH, TOGGLE, DPDT, 125 VOLT, 6 AMP.

TERMINAL BOARD, 12 PT.

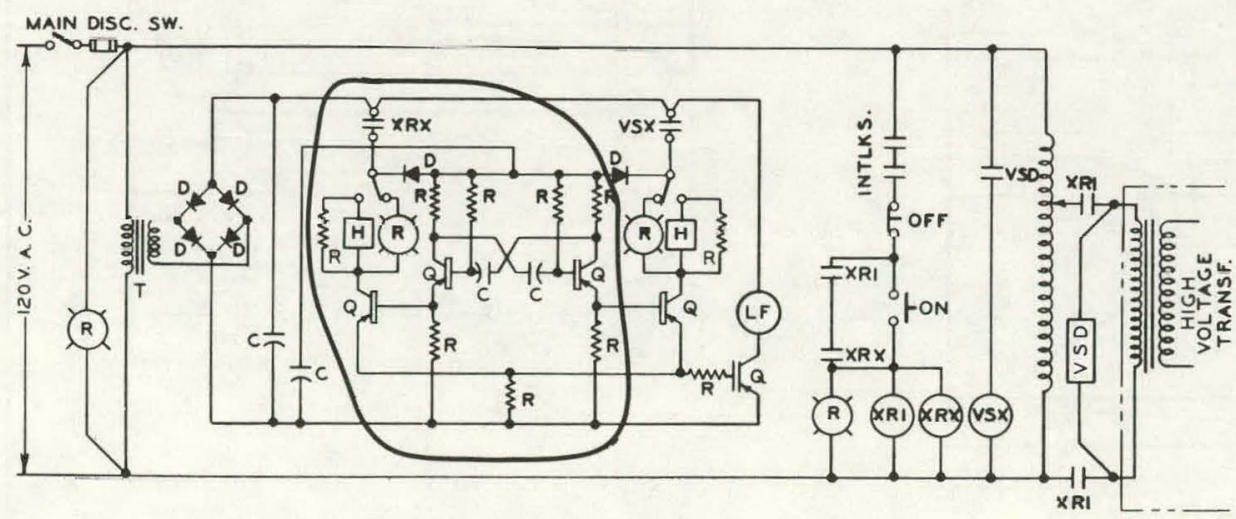

FIG. 2 ELEMENTARY DIAGRAM OF TYPICAL CIRCUIT 
GENERAL

A "VSD ON OR SOURCE EXPOSED-FLASHING" INDICATION IS A RED OR MAGENTA* LIGHT CONNECTED IN THE SYSTEM CONTROL CIRCUIT SUCH THAT WHEN THE RADIATION SOURCE IS ENERGIZED OR THE RADIOACTIVE SOURCE EXPOSED THE RED OR MAGENTA LIGHT WILL BE CYCLED ON AND OFF BY A FLASHER UNIT.

THE "VSD ON OR SOURCE EXPOSED - FLASHING" INDICATING RED OR MAGENTA LIGMT SHALL BE MOUNTED IN DUAL ARRANGEMENT WITH A LIGHT WHICH IS DESCRIBED IN ENGINEERING STANDARD ES-1.9-37. THIS LIGHT SHALL BE MOUNTED APPROXIMATELY AT EYE LEVEL IN THE WORK AND/OR RADIATION AREA SO AS TO WARE PERSONNEL OF. THE EXISTING RADIATION HAZARD. THIS LIGHT WILL BE FLASHING WHILE THE VSD IS ENERG IZED AND/OR BY AN UP-SCALE READING OF A RADIATION MONITOR. THIS FLASHING LIGHT IS REQUIRED ON ALL X-RAY UNITS AND ON ALL SOURCE FACILITIES EQUIPPED WITH A RADIATION MONITOR.

\section{DESCRIPTION}

A "VSD ON OR SOURCE EXPOSED-FLASHING" INDICATING LIGHT THAT COMPLIES' WITH THE REQUIREMENTS OF THIS STANDARD IS SHOWN IN THE

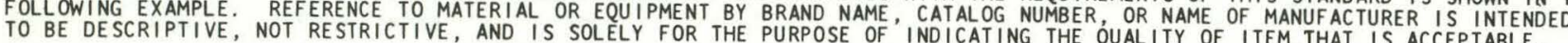

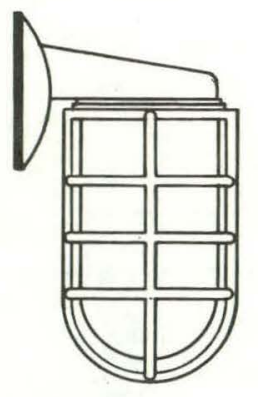

FIG. 1
(*) USE RED LIGHT PENDING REVISION OF ANSI 253.1-1967 AND HEW MORP 68-14.

INCANDESCENT LIGHT FIXTURE VAPORTIGHT

FOR WALL MOUNT ING ON A FOUR-INCH BOX.

FI XTURE SHALL HAVE RED OR MAGENTA GLO

WIRE GUARD, AND 100-WATT LAMP. STONCO

ELECTRIC PRODUCT CO. TYPE WW-IG-PG.
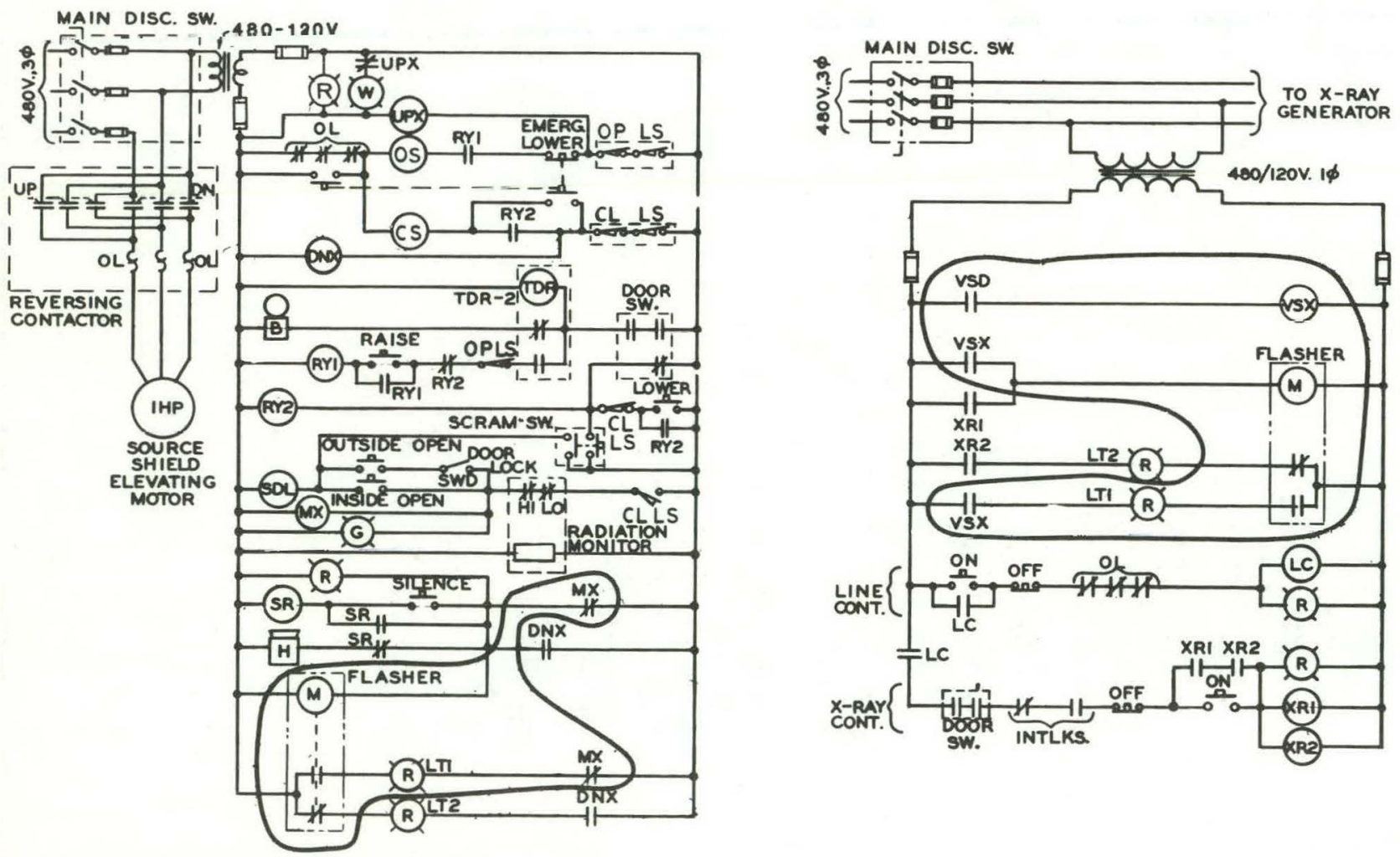

FIG. 2

FIG. 3 
ELEMENTARY DIAGRAMS OF TYPICAL CIRCUITS CONL.
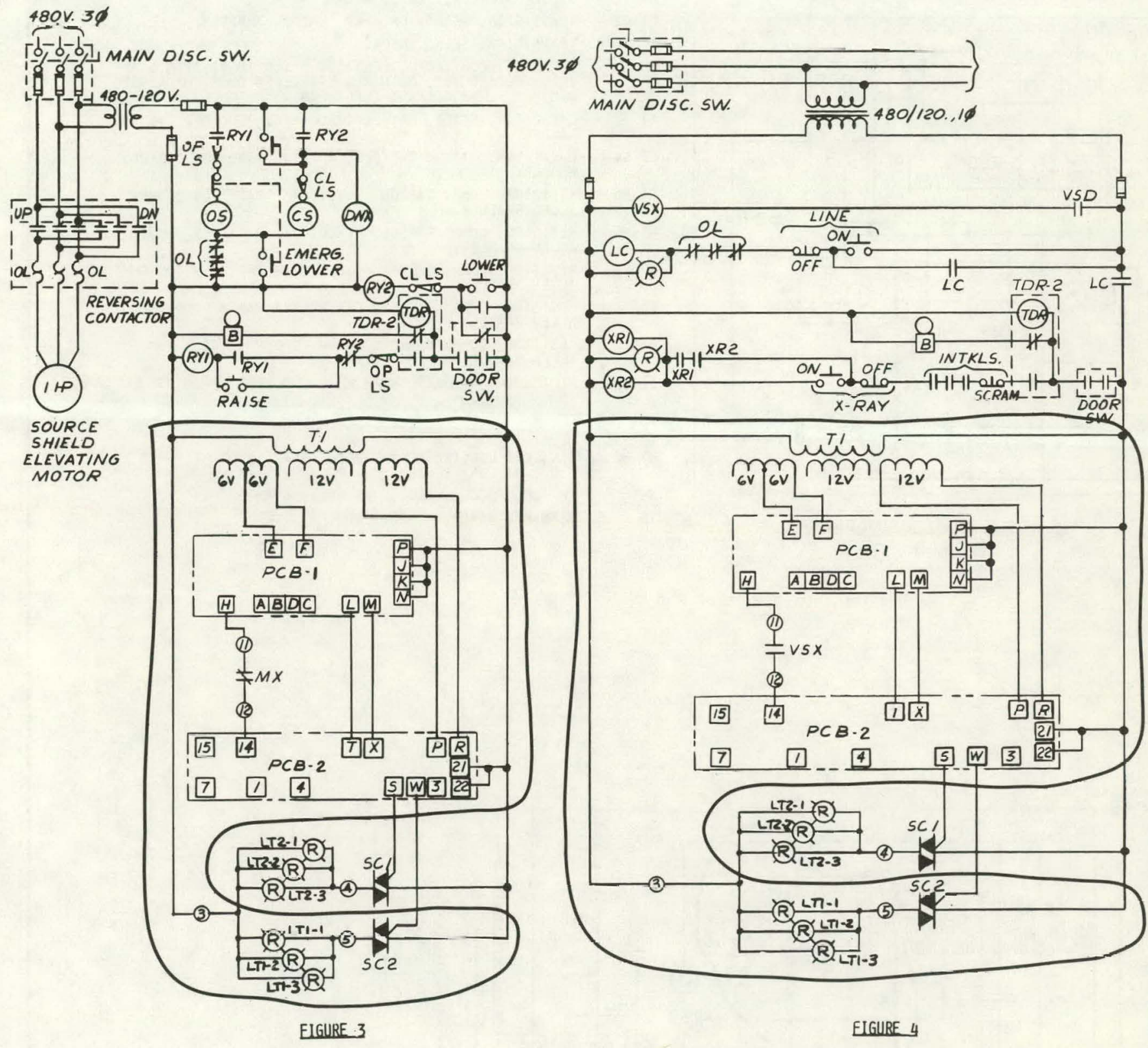

(FOR INSTALLATION WITH MORE THAN TWO. SETS OF 120 VOLT, 100 WATT FLASHING LAMPS,) 


\section{DESCRIPTION}

A "VSD ON OR SOURCE EXPOSED" FLASHING INDICATING LIGHT FOR USE WITH ANALYTICAL X-RAY EQUIPMENT THAT COMPLIES WITH THE REQUIREMENTS OF THIS STANDARD IS SHOWN IN THE FOLLOWING EXAMPLE. REFERENCE TO MATERIAL OR EQUIPMENT BY BRAND NAME, CATALOG NUMBER, OR NAME OF MANUFACTURER IS INTENDED TO BE DESCRIPTIVE, NOT RESTRICTIVE, AND IS SOLELY FOR THE PURPOSE OF. INDICATING THE QUALITY OF ITEM THAT IS ACCEPTABLE. (REF. UCC-ND ENGR. DWGS. C-E-31158 AND C-E-31159.)

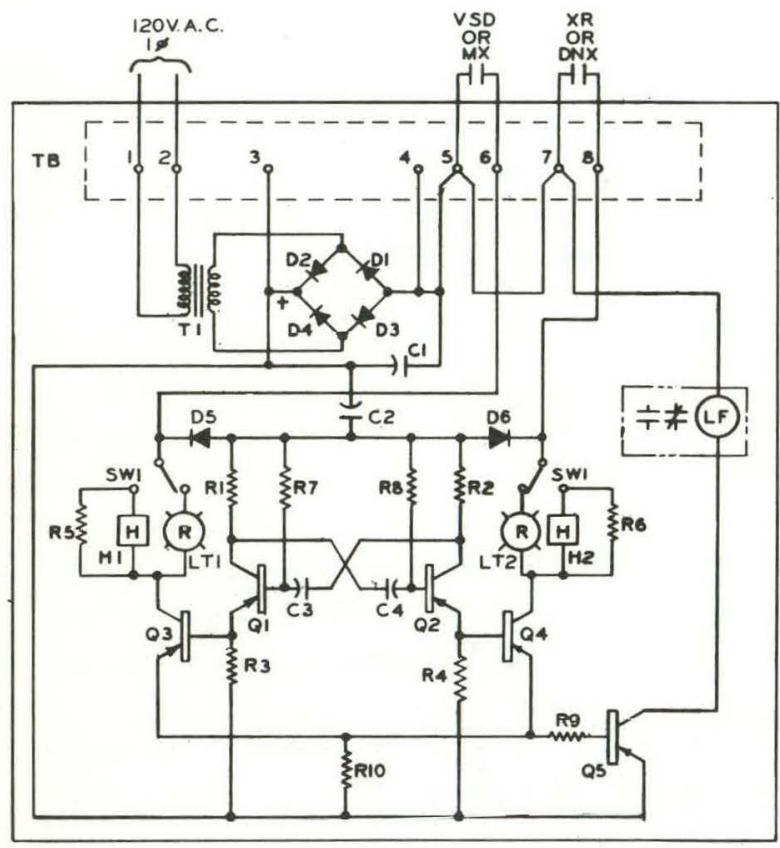

FIG. I ELEMENTARY WIRING DIAGRAM

PCB-1
TI FILAMENT TRANSFORMER, PRI. 117 VOLTS, 60 CYCLES, SEC. 6.3 VOLTS CT AT 1.2 AMPS. THORDARSON $21 \mathrm{~F} 08$.

DI-D6 DIODE, SILICON, TEXAS IN207I.

Q1-Q2 TRANSISTOR, GERMANIUM, PNP, 2N2084 AMPEREX.

Q3-Q5 TRANSISTOR, TEXAS 2 N526.

LF DRY REED RELAY, DPDT CONTACTS RATED 10 VA AT 0.5 AMP COIL VOLTS 6 VDC, COIL RESISTANCE 50 OHMS, MAGNEREED WIO3PCX-5, MAGNECRAFT ELECT. CO.

C1-C2 CAPACITOR, FIXED, DRY ELECTROLYTIC, 1000 MFD, 15 VDC, MALLORY.

C3-C4 CAPACITOR, FIXED, DRY ELECTROLYTIC, 50 MFD, 50 VDC, MALLORY.

R1-R4 RESISTOR, COMP. CARBON, FIXED, 1/2 WATT, 2400 OHMS, ALLEN-BRADLEY.

R5-R6 RESISTOR, COMP. CARBON, FIXED, 1/2 WATT, 51 OHMS,

R7-R8 RESISTOR, COMP, CARBON, FIXED, 1/2 WATT, 27,000 OHMS, RESI STOR, COMP.

R9 RESISTOR, COMP. CARBON, FIXED, 1/2 WATT, 5100 OHMS, ALLEN-BRADLEY.

RIO RESISTOR, COMP. CARBON, FIXED, 1/2 WATT, 2.5 OHM,

LII-LT2 PILOT LIGAT ASSEYBLY, RED LUCITE LENS, FOR T3-1/44-NBB \#47 LAMP, E. F. JOHNSON CO.

H1-H2 SONALERT ELECTRONIC AUDIBLE SIGNAL, $2800 \mathrm{HZ}, 6-28$ VOLTS D.C., MALLORY SC628.

SW1 SWITCH, TOGGLE, DPDT, 125 VOLT, 6 AMP.

TB TERMINAL BOARD, 12 PT.

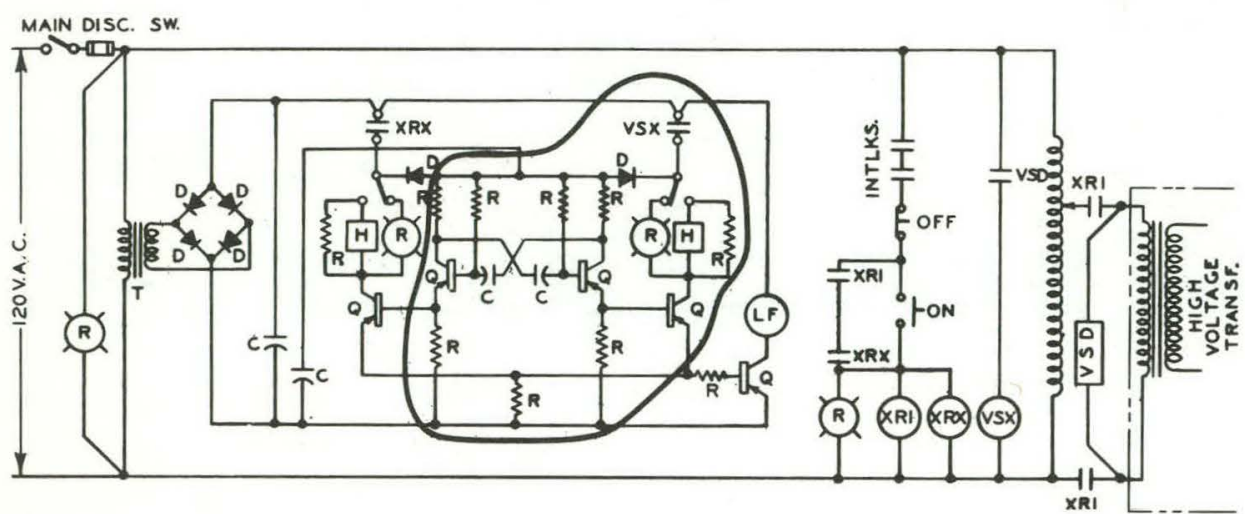

FIG. 2 - ELEMENTARY DIAGRAM OF TYPICAL CIRCUIT 
GENERAL

A "SHUTTER OPEN--FLASHING" INDICATION IS A RED OR MAGENTA* LIGHT CONNECTED IN THE SYSTEM CONTROL CIRCUIT SUCH THAT WHEN THE SHUTTER IS OPEN AND THE RADIATION SOURCE IS ENERGIZED OR THE RAD IOACTIVE SOURCE EXPOSED THE RED OR MAGENTA LIGHT WILL BE CYCLED ON AND OFF BY A FLASHER UNIT.

THE "SHUTTER OPEN--FLASHING" INDICATING RED OR MAGENTA LIGHT SHALL BE MOUNTED IN A NEMA ONE ENCLOSURE IN DUAL ARRANGEMENT WITH A RED OR MAGENTA LIGHT WHICH WILL OPERATE AS DESCRIBED IN ENGINEERING STANDARD ES-1.9-38. THIS LIGHT SHALL BE MOUNTED APPROXIMATELY AT EYE LEVEL IN THE RADIATION AREA SO AS. TO WARN PERSONNEL OF THE EXISTING RADIATION HAZARD. THIS LIGHT WILL BE FLASHING WHILE THE SHUTTER IS OPEN AND THE X-RAY CONTACTOR(S) IS CLOSED AND/OR THE RADIOACTIVE SOURCE IS EXPOSED.

DESCRIPTION

A "SHUTTER OPEN--FLASHING" INDICATING LIGHT THAT COMPLIES WITH THE REQUIREMENTS OF THIS STANDARD IS SHOWN IN THE FOLLOWING EXAMPLE. REFERENCE TO MATERIAL OR EQUIPMENT BY BRAND NAME CATALOG NUMBER OR NAME OF MANUFACTURER IS INTENDED TO BE DESCRIPTIVE, NOT RESTRICTIVE, AND IS SOLELY FOR THE PURPOSE OF INDICATING THE QUALITY OF ITEM THAT IS ACCEPTABLE.

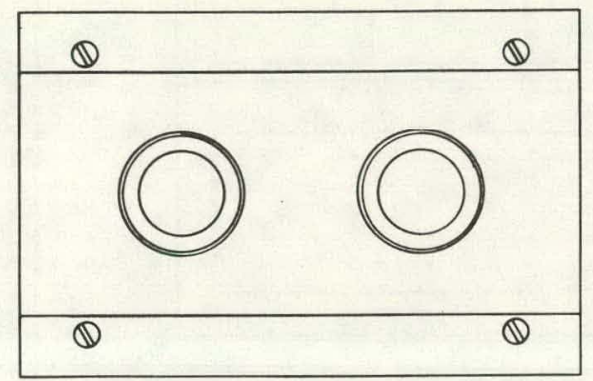

FIG. 1
TWO PILOT LIGHTS, TRANSFORMER TYPE 120 VOLTS, $60 \mathrm{HZ}$ WITH RED OR MÁGENTA COLOR CAP, MOUNTED IN NEMA ONE ENCLOSURE. ALLEN-

BRADLEY BULLET IN $800 T$ T.
( *) USE RED LIGHT PENDING REVISION OF ANSI 253.1-1967 AND HEW MORP $68-14$.

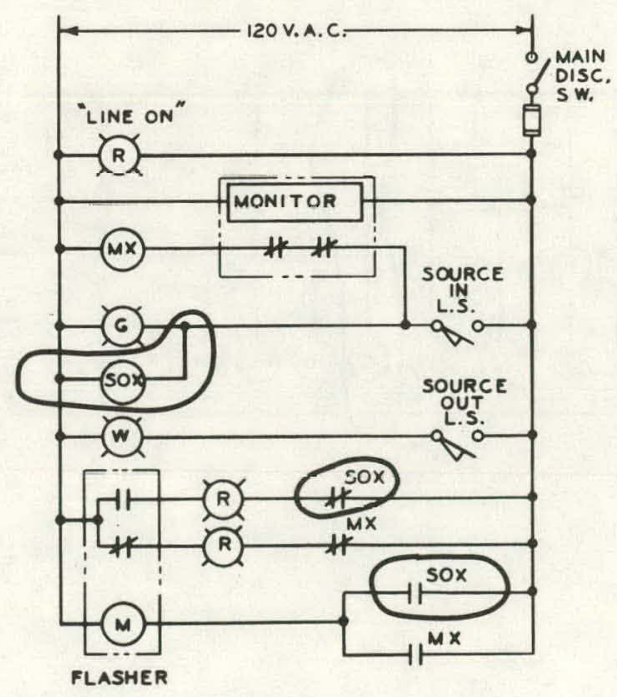

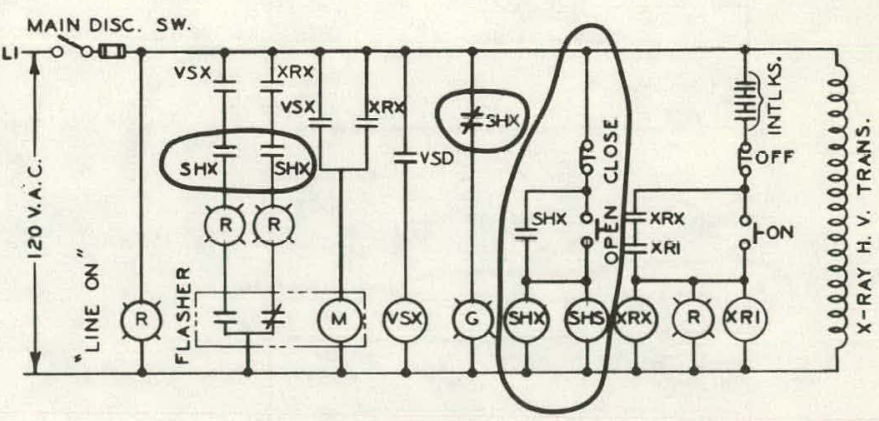

FIG. 3

FIG. 2 


\section{(27) SHUTTER CLOSED-STEADY LIGHT}

ES-1.9-40

GENERAL

A "SHUTTER CLOSED--STEADY LIGHT" INDICATION IS A SMALL GREEN LIGHT CONNECTED IN THE SYSTEM CONTROL CIRCUIT SUCH THAT WHEN THE SHUTTER IS CLOSED ON THE RADIATION SOURCE THE GREEN LIGHT WILL BURN STEADY.

THE "SHUTTER CLOSED" INDICATING GREEN LIGHT SHALL BE MOUNTED ON THE CONTROL PANEL.

\section{DESCRIPTION}

A "SHUTTER CLOSED" INDICATING LIGHT THAT COMPLIES WITH THE REQUIREMENTS OF THIS STANDARD IS SHOWN IN THE FOLLOWING EXAMPLE. REFERENCE TO MATERIAL OR EQU IPMENT BY BRAND NAME, CATALOG NUMBER, OR NAME OF MANUFACTURER IS INTENDED TO BE DESCRIPTIVE, NOT RESTRICTIVE, AND IS SOLELY FOR THE PURPOSE OF INDICATING THE' QUALITY OF ITEM THAT IS ACCEPTABLE.

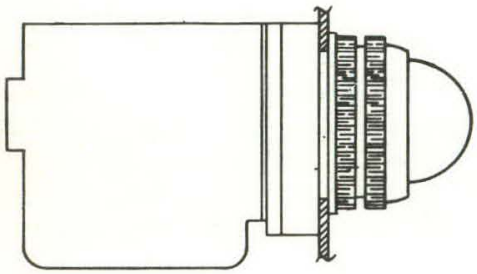

FIG. 1

PILOT LIGHT, TRANSFORMER TYPE, 120

VOLTS, 60 HŹ, WITH A GREEN COLOR CAP.

ALLEN-BRADLEY, BULLETIN 800T.

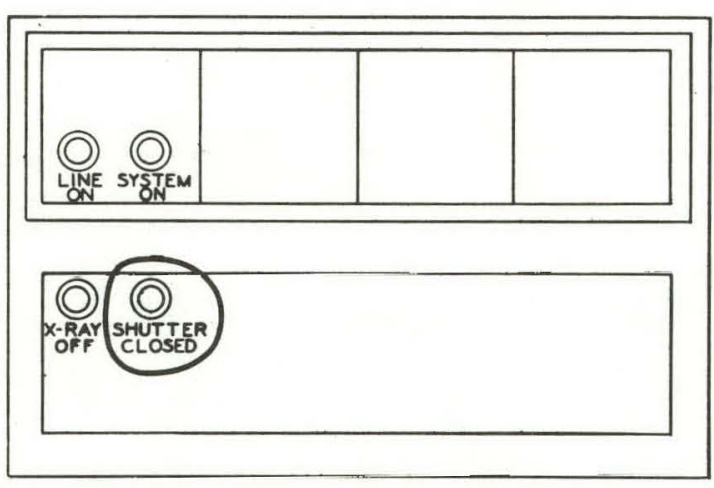

FIG. 2

SAMPLE CONTROL PANEL

ELEMENTARY DIAGRAMS OF TYPICAL CIRCUITS
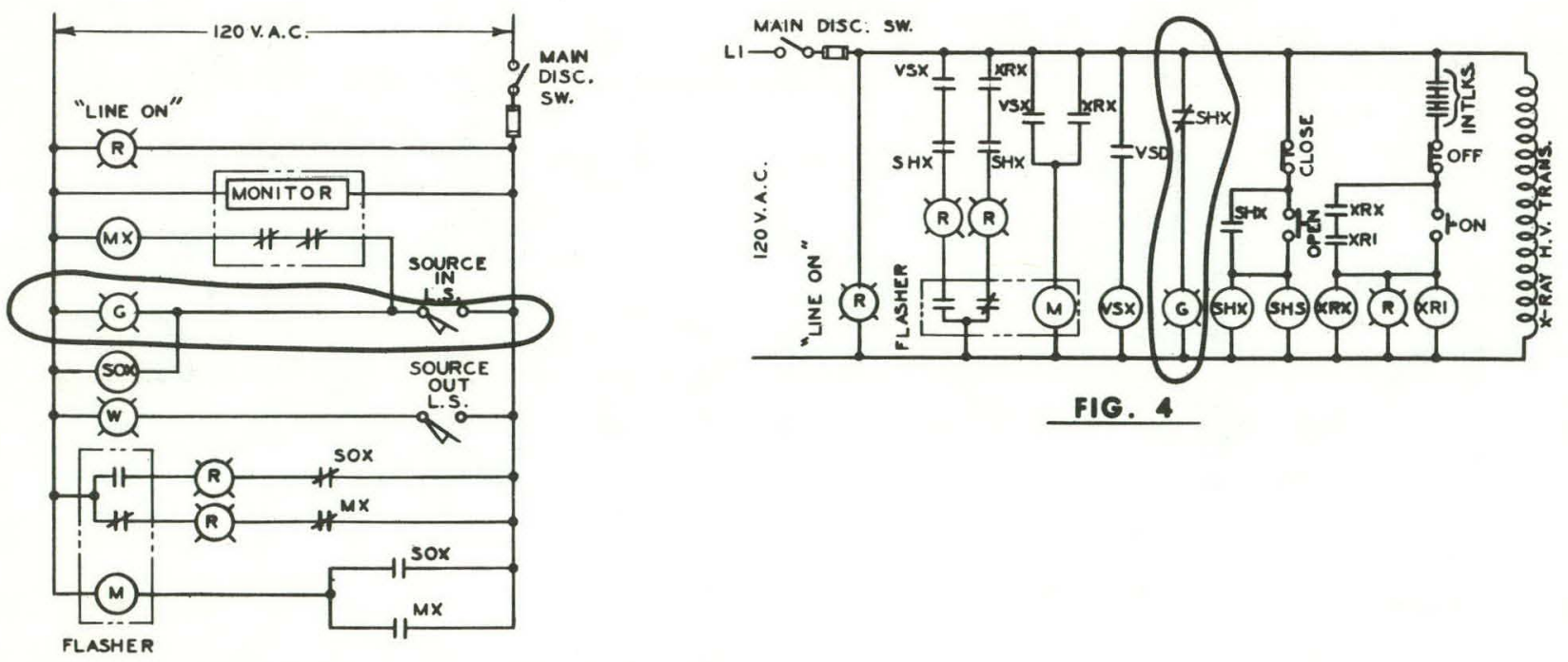

FIG. 3 
GENERAL

AN."X-RAY OFF OR SOURCE SHIELDED" INDICATION IS A SMALL GREEN LIGHT CONNECTED IN THE SYSTEM CONTROL CIRCUIT SUCH THAT WHEN THE RADIATION SOURCE IS DE-ENERGIZED THE GREEN LIGHT WILL BURN STEADY.

THE "X-RAY OFF OR SOURCE SHIELDED" INDICATING GREEN LIGHT SHALL BE MOUNTED ON THE CONTROL PANEL AND BE ENERGIZED WHEN THE $X$-RAY HIGH VOLTAGE IS OFF OR SOURCE IS SHIELDED.

\section{DESCRIPTION}

AN "X-RAY OFF OR SOURCE SHIELDED" INDICATING LIGHT THAT COMPLIES WITH THE REQUIREMENTS OF THIS STANDARD IS SHOWN IN THE FOLLOWING EXAMPLE. REFERENCE TO MATERIAL OR EQUIPMENT BY BRAND NAME, CATALOG NUMBER, OR NAME OF MANUFACTURER IS INTENDED TO BE DESCRIPTIVE, NOT RESTRICTIVE, AND IS SOLELY FOR THE PURPOSE OF IND ICATING THE QUALITY OF ITEM THAT IS ACCEPTABLE.

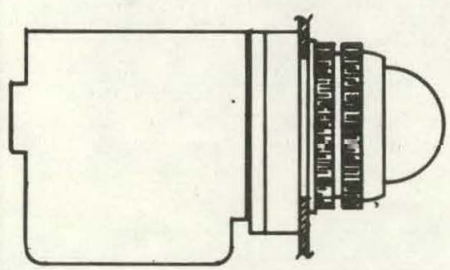

FIG. 1

PILOT LIGHT, TRANSFORMER TYPE, 120 VOLTS, 60 HZ, WITH A GREEN COLOR CAP. ALLEN-BRADLEY, BULLETIN BOOT.

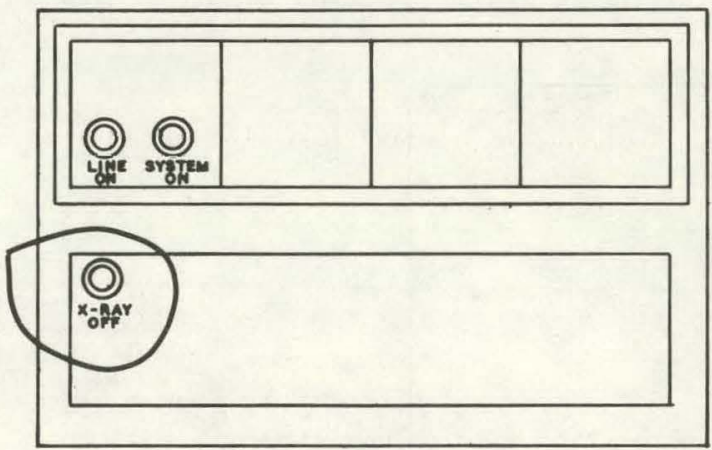

FIQ. 2

SAMPLE CONTROL PANEL

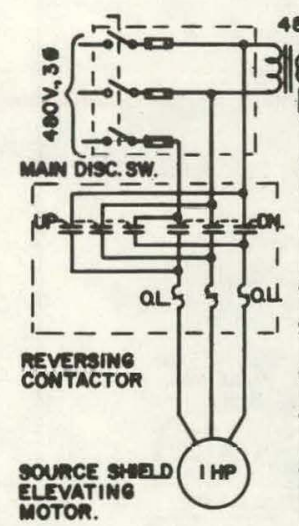

$480-120 \mathrm{~V}, 10$

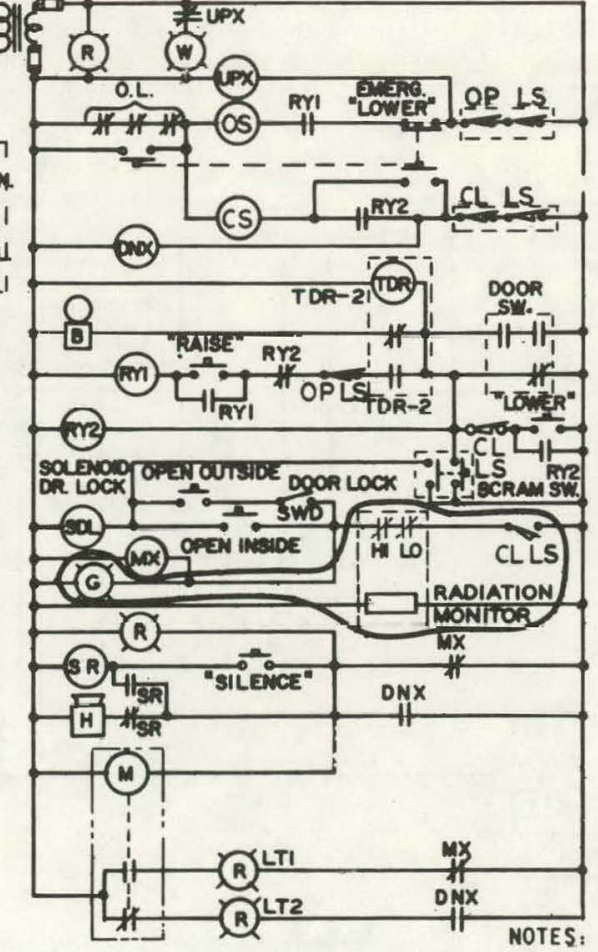

FIG. 3
1. ADO CIRCIIIT IN DASHED LINES

WHEN NUCLEAR SOURCE IS INSTALLED IN SAME FACILITY AS X-RAY.

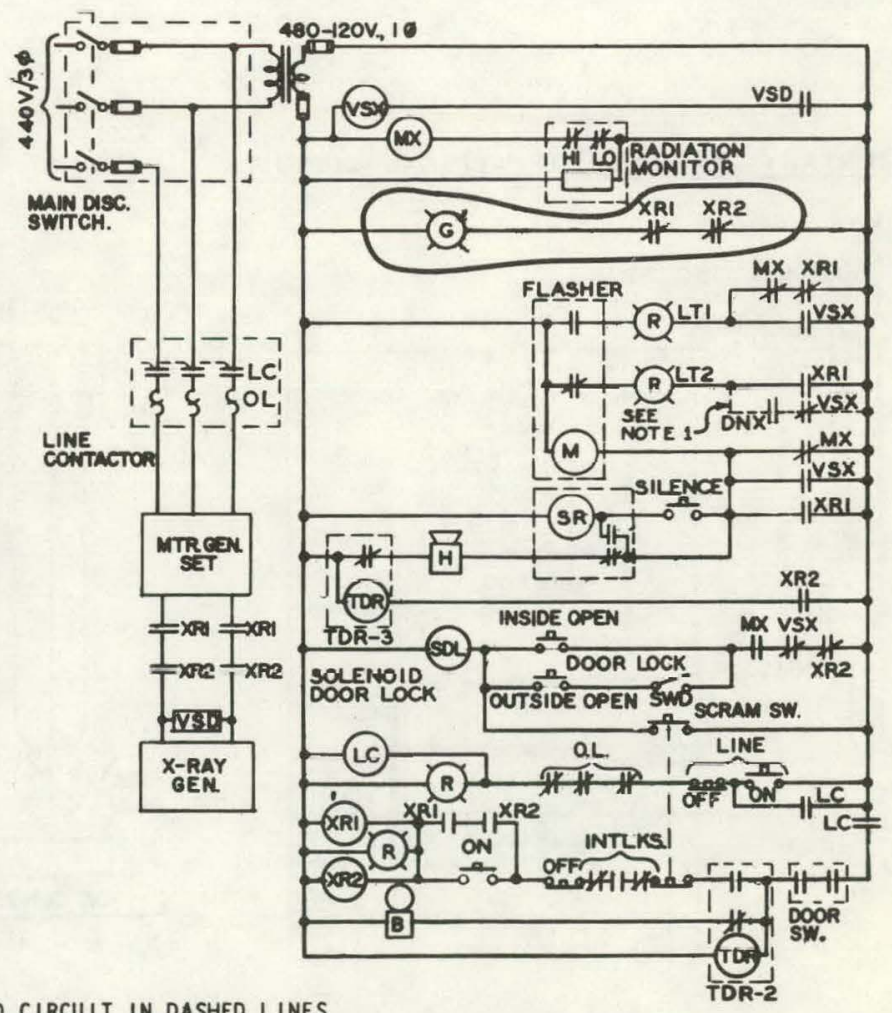

FIC. 4 
GENERAL

A BELL IS AN ELECTRICAL NOISE SIGNAL DEVICE CONNECTED IN THE SYSTEM CONTROL CIRCUIT SUCH THAT A WARNING WILL BE GIVEN BEFORE THE RADITATION SOURCE CAN BE ENERGIZED.

A BELL SHALL BE MOUNTED ON THE INSIDE OF THE VAULT, ROOM, OR ENCLOSURE AND SHALL BE ENERGIZED FOR FIVE SECONDS WHEN THE DOOR OR OTHER ACCESS TO THE AREA IS CLOSED. THIS SIGNAL WILL SERVE AS THE FIRST WARNING TO ANY PERSONNEL IN SUCH AN AREA THAT THE AREA SHOULD BE EVACUATED, OR THE SCRAM SWITCH ACTIVATED TO PREVENT ENERGIZING THE X-RAY UNIT.

\section{DESCRIPTION}

A BELL THAT COMPLIES WITH THE REQUIREMENTS OF THIS STANDARD IS SHOWN IN THE FOLLOWING EXAMPLE. REFERENCE TO MATERIAL OR EQUIPMENT BY BRAND NAME, CATALOG NUMBER, OR NAME OF MANUFACTURER IS INTENDED TO BE DESCRIPTIVE, NOT RESTRICTIVE, AND IS SOLELY FOR THE PURPOSE OF INDICATING THE QUALITY OF ITEM THAT IS ACCEPTABLE.

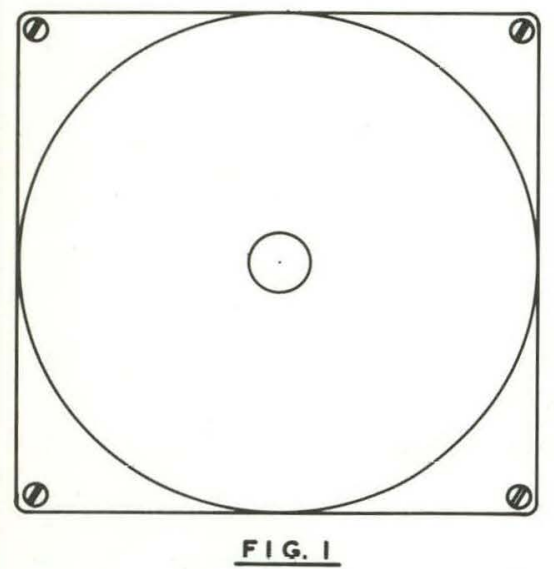

BELL, VIBRATING TYPE, FOUR-INCH INTERIOR MODEL, SUITABLE FOR MOUNTING ON STANDARD FOUR-INCH SQUARE BOX.' BELL TO OPERATE ON 120 VOLTS A.C., $60 \mathrm{HZ}$. FEDERAL SIGN AND

SIGNAL CORPORATION, CLASS 500 , MODEL $504 \mathrm{~N}$.

ELEMENTARY DIAGRAMS OF TYPICAL CIRCUITS
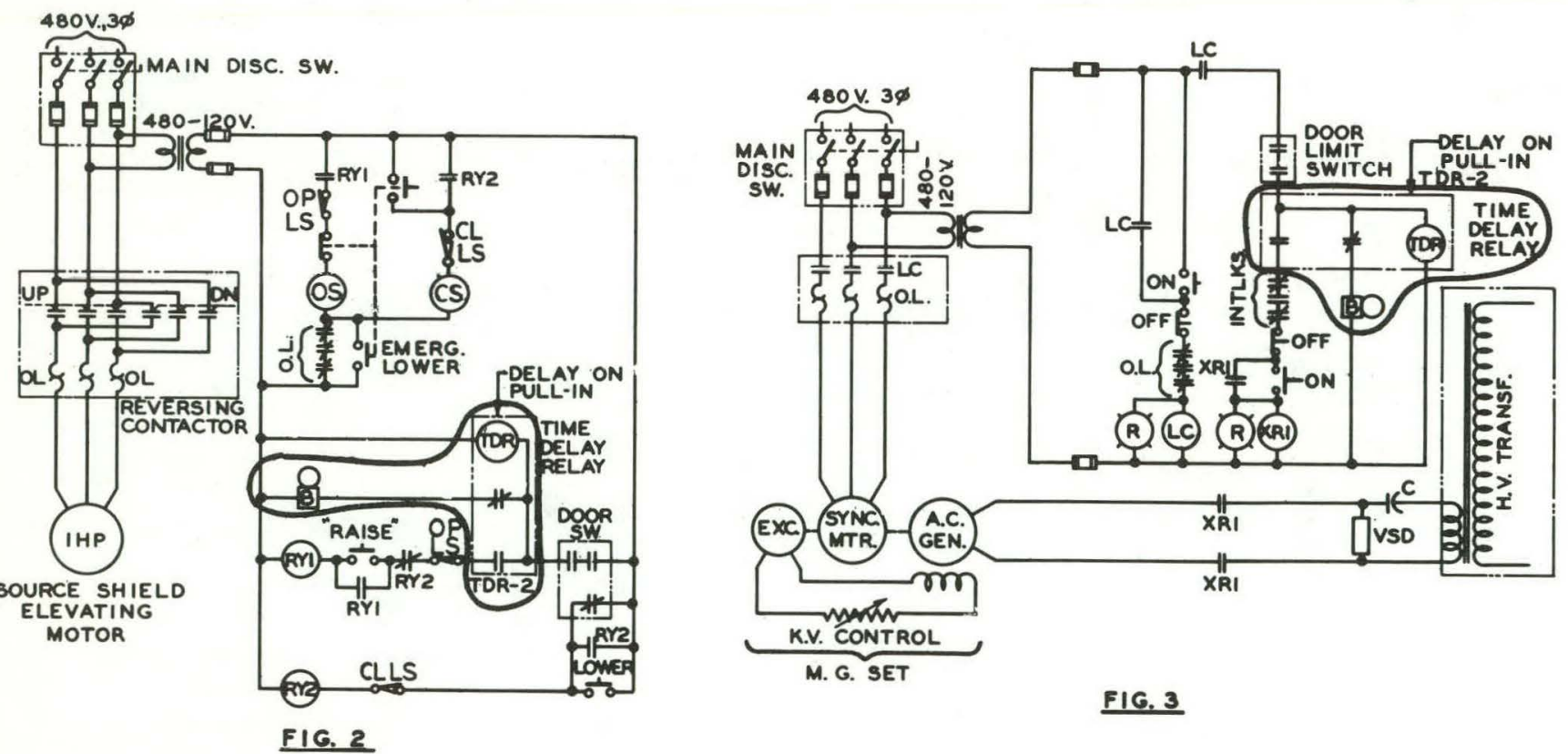

$\underline{F I G .3}$ 
GENERAL

A HORN IS AN ELECTRICAL NOISE SIGNAL DEVICE CONNECTED IN THE SYSTEM CONTROL CIRCUIT SUCH THAT A WARNING WILL BE GIVEN WHEN THE RADIATION SOURCE HAS BEEN ENERGIZED.

A HORN SHALL BE MOUNTED ON THE INSIDE OF THE VAULT, ROOM, OR ENCLOSURE AND SHALL BE ENERGIZED FOR FIVE SECONDS UPON ACTIVATION OF THE "X-RAY ON" OR "SOURCE EXPOSED" CONTROLS. THIS SIGNAL WILL SERVE AS A FINAL WARNING TO ANY PERSONNEL IN SUCH AN AREA THAT THERE IS RADIATION DANGER AND THE "SCRAM SWITCH" MUST BE ACTIVATED IMMEDIATELY.

\section{DESCRIPTION}

A HORN THAT COMPL.IES WITH THE REQUIREMENTS OF THIS STANDARD IS SHOWN IN THE FOLLOWING EXAMPLE. REFERENCE TO MATERIAL OR EQUIPMENT BY BRAND NAME, CATALOG NUMBER, OR NAME OF MANUFACTURER IS INTENDED TO BE DESCRIPTIVE, NOT RESTRICTIVE, AND IS SOLELY FOR THE PURPOSE OF INDICATING THE QUALITY OF ITEM THAT IS ACCEPTABLE.

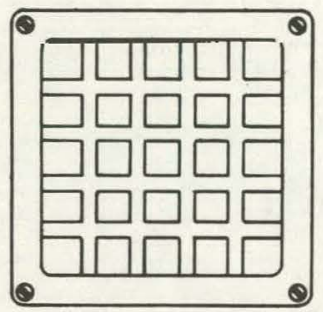

HORN, VIBRATING TYPE, FOUR-INCH INTERIOR MODEL,

SUITABLE FOR MOUNTING ON STANDARD FOUR-INCH SQU ARE

BOX. HORN TO OPERATE ON 120 VOLTS A.C., $60 \mathrm{HZ}$.

FIG. 1
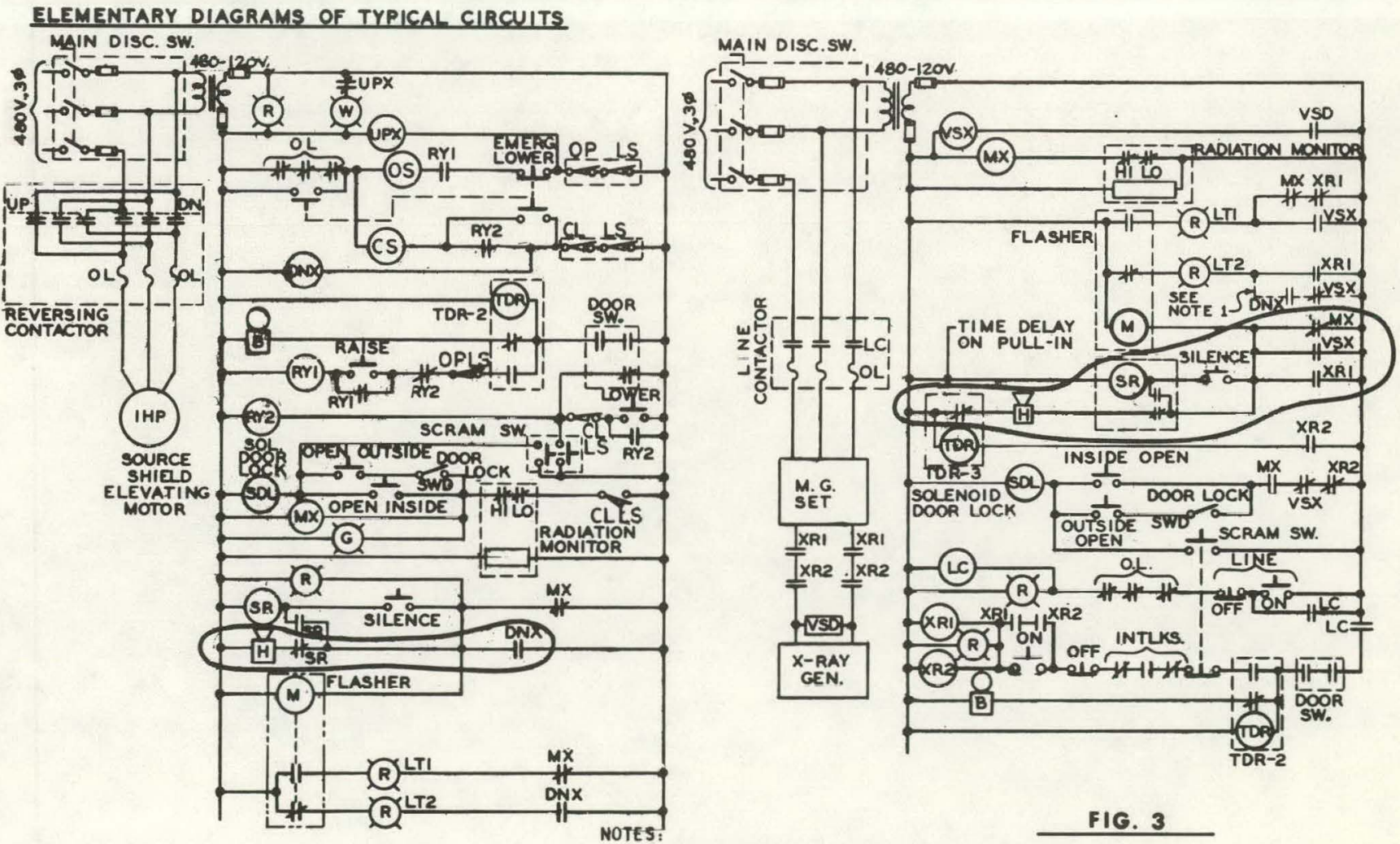

FIG. 3

FIG. 2

1. ADD CIRCUIT IN DASHED LINES WHEN NUCLEAR SOURCE IS INSTALLED IN SAME FACILITY AS X-RAY. 


\section{General}

A barricade is a physical obstruction for the purpose of keeping personnel away from a radiation area. Barricades will be used when it is impractical or impossible to enclose the radiation producing equipment in a vault.

Barricades are divided into two categories: light and medium. Light barricades consist of ropes or chains with appropriate signs attached and may be used when the level of exposure is less than $100 \mathrm{mrem} / \mathrm{hr}$. or on a temporary basis at higher levels if an operator is in attendance at all times. Medium barricades consist of fences or partitions which are more substantial than light barricades and may be used when the radiation level exceeds $100 \mathrm{mrem} / \mathrm{hr}$. and the equipment is left unattended. Where an electrical interlock is required by the safety features review committee to be used with a medium barricade, Reference ES-1.9-25 should be used in conjunction with this reference.

Examples of light and medium barricades are shown in Figures 1 and 2. 


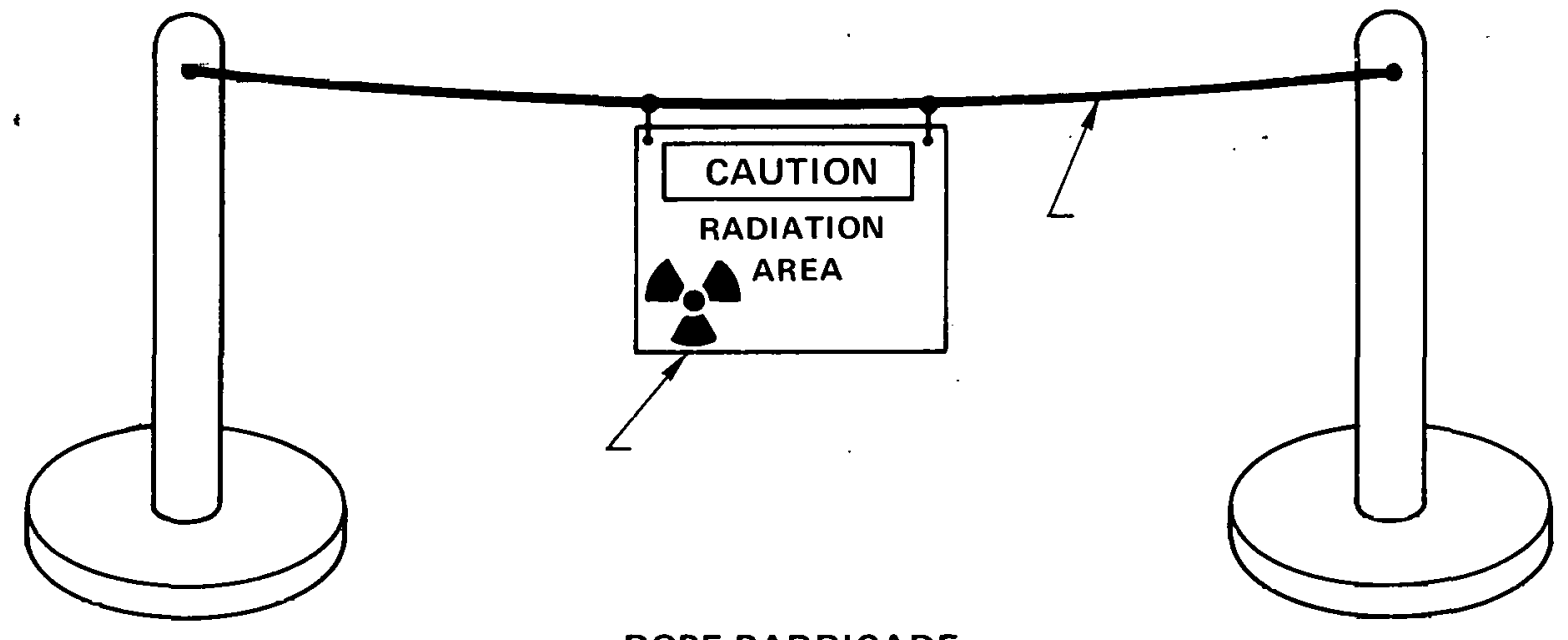

ROPE BARRICADE

FIG. 1

Notes

(1) Industrial Products Co. "Polyrope", 5/16" dia., 2 strands yellow, 1 strand magenta, Cat. \#10R.

(2) Reference ES-1.9-33 for signs. 


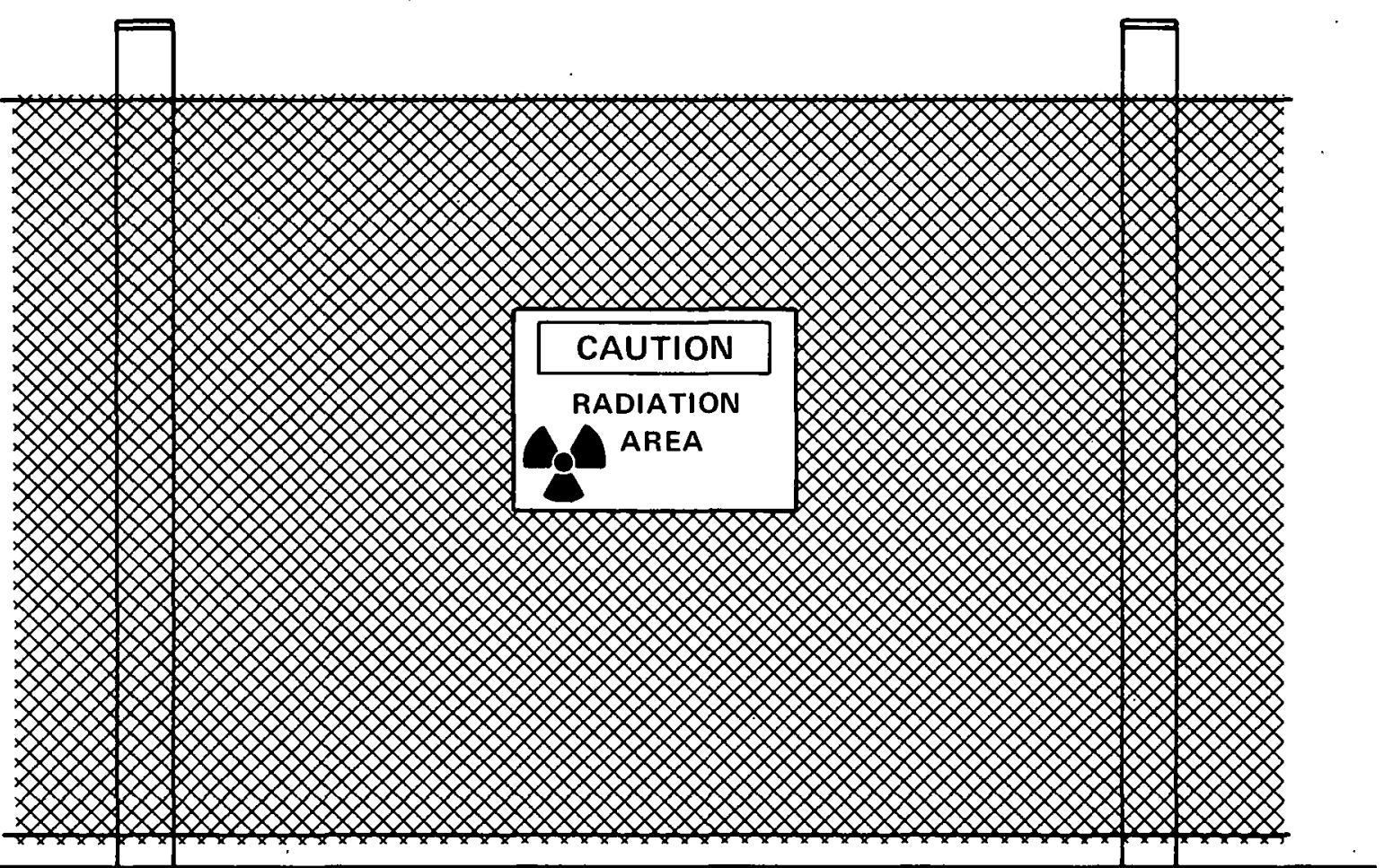

FENCE BARRICADE

FIG. 2

Notes

(1) Reference ES-1.9-33 for signs. 


\section{General}

A padlock is a key operated mechanical device for fastening a door, electrical disconnect switch, shield cover, drawer, etc.

Padlocks will be used to assure that unauthorized persons cannot operate $X$-ray equipment or expose certain sources. They will be used when equipment or sóurces are in storage and when it is desirable to lock out the main power disconnect switch on $\mathrm{X}$-ray equipment. 


\section{Distribution}

Aerojet Nuclear Company

Sommers, J. F.

\section{Allied Chemical Company}

Rich, B. L.

\section{Ames Laboratory}

Voss, M. D.

Argonne National Laboratory - Argonne

Dillow, W. D.

Argonne National Laboratory - Idaho Falls

Holson, C. E.

Atlantic Richfield Hanford Company

McMurray, B. J,

Battelle Memorial Institute - Columbus

Mckown, D. A.

Battelle Memorial Institute - Richland

Heid, K. R.

Bendix Corporation - Kansas City

Ochoa, J. D.

Brookhaven National Laboratory

Meinhold, P. C.

Carnegie Mellon University

Bomba, F. J.

$E \mathbf{G}$ and $\mathbf{G}$ - Las Vegas

Jupiter, C. P.

E. I. duPont deNemours and Company - Aiken

Patterson, C. M.

Eberline Instrument Corporation

Geiger, E. L.

Energy Research and Development

Administration - Albuquerque

Miller, R. L.
Energy Research and Development Administration - Idaho Falls

Horan, J. R.

Energy Research and Development Administration - Las Vegas

Church, B.W.

Energy Research and Development Administration - New York

Breslin, A. J.

Harley, J. H.

Energy Research and Development Administration - Oak Ridge

Baker, H. O.

Brewington, $P$.

- Hickman, H. D.

Leed, R. E.

Lenhard, J. A.

Travis, W. H.

Zachry. D. S.

Energy Research and Development Administration - Richhland

Rhoades, P. G.

Energy Research and Development Administration - Savannah

Smith, H. P.

Energy Research and Development Administration - Schenectady

Vodapivc, G. J.

Energy Research and Development Administration - Washington

Ross, D. M.

General Dynamics - Fort Worth

Paschal, F. L.

General Electric Company - Schenectady Warden, J. E. S.

General Electric Company - St. Petersburg

Forest, E. P. 
Goodyear Atomic Corporation

Hulett, S. H.

Gulf Energy and Environmental Systems

Bold, F. O.

Hanford Industrial Development Laboratory

Howell, W. P.

International Chemical and Nuclear

Baietti, A. L.

Los Alamos Scientific Laboratory

Drummer, J. E.

Healy, J. W.

Mason and Hanger - Amarillo

Phillips, $\mathrm{H}$.

Mason and Hanger - Burlington

Shannan, J. E.

Mound Laboratory

Adams, P. C.

National Lead Company of Ohio

Heatherton, R. C.

Oak Ridge Associated Universities

Berger, J. D.

Cloutier, R. J.

Oak Ridge Gaseous Diffusion Plant

Bailey..J. C.

Mason, W. J.

Wilsnx, W. I.

Winkle, R. A.

Stief, S. S.

Oak Ridge National Laboratory

Affel, R. G.

Auxier, J. A.

Bruce, R. F.

Cottrell, W. B.

Davis, D. M.

Steed, J. A.

Oak Ridge Y-12 Plant

Alvey, H. E.
Briscoe, O.W.

Burditt, R. B.

Burkhart, L. E.

Butturini, W. G.

Duggan, H. G.

Ebert, J.W.

Ellingson, R. D.

Fraser, R. J.

Gambill, E. F.

Gritzner, V. B.

Hensley, C. E.

Jackson, V. C.

Johnson, C. E.

Jones, D. A.

Kahl, K. G.

Keith, A.

Kitè, H. I.

McLendon, J. D.

Oliphant, G. W.

Perry, A. E.

Phillips, L. R.

Pipes, E. W.

Smith, H. F., Jr

Smith, H. G.

Smith, J. P.

Smith, R. D.

Snyder, H. G. P:

Stoner, H. H.

Weathersby, W. E.

West, C. M.

White, J. C.

Whitson, W. K.

Yaggi, W. J./Googin, J. M.

Y-12 Central Files (master copy)

$Y-12$ Central Files (route copy)

$Y-12$ Central Files $(Y-12 R C)$

$Y=12$ Cerilial Files (50)

Zang, H. W.

Zanolli, G. F.

Zerby, C. D.

Paducah Gaseous Diffusion Plant

Edwards, A. K.

Rockwell International

Putzier, E. A.

Sandia - Albuquerque

K.ingsiey, W. H. 


\author{
Sandia - Livermore \\ Lovell, P. K. \\ Sloan Physical Laboratories \\ Holeman, G. R. \\ Union Carbide Corporation - New York \\ McDaniel, P.W. \\ Union Carbide Corporation - South Charleston \\ Ketcham, N. H. \\ United Nuclear Industries \\ Corbit, C. P. \\ University of California - Berkeley \\ Latimer, R. M. \\ University of California - Livermore \\ Tinney, J. F. \\ University of Rochester \\ Mallie, $\mathrm{H}$. \\ Westinghouse Astronuclear Laboratory \\ Boobo, M. R. \\ Westinghouse Electric Corporation - Idaho Falls \\ Doncsecz, D. E. \\ Westinghouse Electric Corporation - West Mifflin \\ Bogar, L. C.
}

